medRxiv preprint doi: https://doi.org/10.1101/2021.03.02.21252684; this version posted March 27, 2021. The copyright holder for this preprint

(which was not certified by peer review) is the author/funder, who has granted medRxiv a license to display the preprint in perpetuity.

All rights reserved. No reuse allowed without permission.

\title{
Meta-analytic findings on reading in children with cochlear implants
}

Yingying Wang ${ }^{1,2,3^{*}}$, Fatima Sibaii ${ }^{1,2}$, Kejin Lee ${ }^{3}$, Makayla J. Gill ${ }^{1,2}$, Jonathan L. Hatch ${ }^{4}$

${ }^{1}$ Neuroimaging for Language, Literacy and Learning Lab, Department of Special Education and

Communication Disorders, University of Nebraska-Lincoln, NE, U.S. 68583

${ }^{2}$ Center for Brain, Biology and Behavior, University of Nebraska-Lincoln, NE, U.S. 68588

${ }^{3}$ Nebraska Center for Research on Children, Youth, Families and Schools, University of Nebraska-Lincoln,

NE, U.S. 68583

${ }^{4}$ Department of Otolaryngology-Head \& Neck Surgery, University of Nebraska Medical Center, Omaha,

NE, U.S. 68198

All correspondence should be addressed to:

Yingying Wang, 113 Barkley Memorial Center, Lincoln, NE 68583, USA. E-mail: yingying.wang@unl.edu

Phone: 531.289.8089 
medRxiv preprint doi: https://doi.org/10.1101/2021.03.02.21252684; this version posted March 27, 2021. The copyright holder for this preprint (which was not certified by peer review) is the author/funder, who has granted medRxiv a license to display the preprint in perpetuity.

All rights reserved. No reuse allowed without permission.

Conflict of Interest: There are no relevant conflicts of interest.

Acknowledgments: This work was supported by the National Institute on Deafness and Other Communication Disorders [5R21DC018110, 2019]; the Barkley Trust, Nebraska Tobacco Settlement Biomedical Research Development, College of Education and Human Sciences, and the Office of Research and Economic Development at University of Nebraska-Lincoln (UNL). The content of this paper is solely the responsibility of the authors and does not necessarily represent the official views of the NIH. The undergraduate research assistant (Makayla J. Gill) was supported by the UNL Undergraduate Creative Activities and Research Experience (UCARE) program funded in part by gifts from the Pepsi Quasi Endowment and Union Bank \& Trust. Many thanks to Dr. Michelle L. Hughes for providing her constructive comments. Y.W. conceptualized research ideas, performed meta-analyses, and wrote the main paper. F.S. coded all the articles, performed initial analysis, and drafted part of the paper. K.L. provided statistical analysis, wrote $\mathrm{R}$ codes to analyze and valid results, and edited the statistical methodology part in the paper. M.J.G coded $80 \%$ of the studies and edited the paper. J.H. reviewed and edited the paper. All authors commented on the manuscripts before the submission. All authors declare that there is no conflict of interest. The data that support the findings of this study are available by request to the corresponding author. 
medRxiv preprint doi: https://doi.org/10.1101/2021.03.02.21252684; this version posted March 27, 2021. The copyright holder for this preprint (which was not certified by peer review) is the author/funder, who has granted medRxiv a license to display the preprint in perpetuity. All rights reserved. No reuse allowed without permission.

\begin{abstract}
This meta-analysis study aims to quantify the group differences in reading skills between children with cochlear implants and their hearing peers and between children with cochlear implants and children with hearing aids (aged between 3 to 18 years old). Of the 5,642 articles screened, 47 articles met predetermined inclusion criteria (published between 2002 and 2019). The robust variance estimation based meta-analysis models were used to synthesize all the effect sizes. Children with cochlear implants scored significantly lower than their hearing peers in phonological awareness ( $\mathrm{g}=$ $1.62, \mathrm{p}<.001)$, vocabulary $(\mathrm{g}=-1.50, \mathrm{p}<.001)$, decoding $(\mathrm{g}=-1.24, \mathrm{p}<.001)$, and reading comprehension $(g=-1.39, p<.001)$, but not for fluency $(g=-.67, p=.054)$. Compared to children with hearing aids, children with cochlear implants scored significantly lower in phonological awareness $(\mathrm{g}=-$ $.30, p=.028)$. The percentage of unilateral cochlear implant negatively impacts the group difference between children with cochlear implants and their hearing peers. Findings from this study confirm a positive shift in reading outcomes for profoundly deaf children due to cochlear implantation. Some children with cochlear implants may need additional supports in educational settings.
\end{abstract}


medRxiv preprint doi: https://doi.org/10.1101/2021.03.02.21252684; this version posted March 27, 2021. The copyright holder for this preprint (which was not certified by peer review) is the author/funder, who has granted medRxiv a license to display the preprint in perpetuity.

All rights reserved. No reuse allowed without permission.

Learning to read plays an essential role in a child's social and cognitive development, and children who read well are more likely to achieve educational and vocational success (Butler et al., 1985; Kern \& Friedman, 2009). Many children who are deaf and hard of hearing (DHH) face serious challenges in accessing the auditory information of reading (i.e., phonological processing and letter-sound correspondences) when learning to read (Herman, Roy, \& Kyle, 2017). Since the early 1990s, the expansion of Early Hearing Detection and Intervention (EHDI) programs has dramatically increased the number of infants identified with hearing loss within the first year of life in the United States (CDC, 2017). As a result, more infants with hearing loss have received early diagnosis and treatment such as cochlear implantation and hearing-aid fitting. A review article reported that most children who are DHH successfully develop spoken language after cochlear implantation (Ganek, McConkey Robbins, \& Niparko, 2012). Many studies reported that children with cochlear implants (Cls) had improved speech perception and production skills (Blamey et al., 2001; A. Geers et al., 2008; Niparko, Tobey, Thal, Eisenberg, Wang, Quittner, Fink, et al., 2010; Wang et al., 2018; Yoshinaga-Itano et al., 2018). Given the positive relationship between spoken language and reading development in children with typical hearing (TH) (Snowling \& Melby-Lervåg, 2016), it is reasonable to suggest that DHH children may benefit from using cochlear implants when learning to read. However, there is considerable variability in cochlear implantation benefits on various emergent and later reading skills.

Learning to read occurs long before children begin to receive formal reading instruction in school. During early childhood, phonological awareness (PA) is critical for reading development in children with TH and has been suggested to be a strong predictor of reading outcomes (Shanahan \& Lonigan, 2010). PA is an umbrella term representing the ability to abstract and manipulate segments of spoken language (i.e., blending or deletion) (Spencer \& Tomblin, 2009). Despite the early access to spoken language through cochlear implantation, children with Cls still scored significantly lower than children with TH on PA tasks (Bell et al., 2019; Johnson \& Goswami, 2010; Nittrouer, Lowenstein, \& 
medRxiv preprint doi: https://doi.org/10.1101/2021.03.02.21252684; this version posted March 27, 2021. The copyright holder for this preprint (which was not certified by peer review) is the author/funder, who has granted medRxiv a license to display the preprint in perpetuity.

All rights reserved. No reuse allowed without permission.

Holloman, 2016b). Compared to children with hearing aids (HAs), children with Cls had significantly lower scores for the rhyme task, but equivalent scores in the syllable and phoneme tasks (James, Brown, \& Brinton, 2005). However, Nittrouer et al. (2012b) found both groups of children with hearing loss had significantly lower scores on phoneme tasks than their hearing peers and no significant differences in PA skills between 25 children with Cls and 8 children with HAs. The lack of differences in PA skills between the $\mathrm{Cl}$ and $\mathrm{HA}$ groups might be due to the small sample size of the $\mathrm{HA}$ group.

The developmental sequence of learning to read for children with TH holds for children who are DHH, based on the report from National Center for Special Education Research (Connor et al., 2014) and the Qualitative Similarity Hypothesis (QSH) (Paul \& Alqraini, 2019). For instance, the Simple View of Reading (SVR), as an influential model for children with TH, supports that reading comprehension is not a serial process with decoding preceding linguistic comprehension but rather interactive ("product") processes that involve both decoding and linguistic comprehension (Gough \& Tunmer, 1986). The SVR also holds for children who are DHH (Beverly Trezek \& Mayer, 2019). Vocabulary knowledge, viewed as part of oral language, is a key linguistic skill that supports reading development in both children with $\mathrm{TH}$ (Muter et al., 2004) and children who are DHH (Easterbrooks et al., 2008; Geers, 2003; Worsfold et al., 2018). Children with TH develop vocabulary receptively and expressively. Receptive language vocabulary refers to words understood when they are heard or read (Vatalaro et al., 2018). Expressive language vocabulary refers to words expressed aloud. As early as 12 months, typically developing infants are learning new words rapidly and have 200-300-word expressive vocabulary on average by the age of three (Fenson et al., 1994). Children with Cls usually gain access to auditory inputs and learn spoken language at least a year later than their hearing peers. Some studies found children with $\mathrm{Cls}$ scored significantly lower than children with TH in receptive vocabulary tasks (Ambrose, 2009; Bell et al., 2019), while Nittrouer et al. (2018) demonstrated that children with TH were outperformed children with Cls in expressive vocabulary tasks. Moreover, Schorr et al. (2008) identified significantly lower performance in 
medRxiv preprint doi: https://doi.org/10.1101/2021.03.02.21252684; this version posted March 27, 2021. The copyright holder for this preprint (which was not certified by peer review) is the author/funder, who has granted medRxiv a license to display the preprint in perpetuity.

All rights reserved. No reuse allowed without permission.

both receptive and expressive vocabulary tasks for children with Cls when compared to their hearing peers. A recent meta-analysis evaluated 12 articles and also supported that children with Cls scored significantly lower than their hearing peers in both vocabulary tasks (Lund, 2016). On the contrary, other studies have reported that children with Cls did not perform significantly differently in receptive and expressive vocabulary tasks than their hearing peers (Luckhurst et al., 2013; Wechsler-Kashi et al., 2014). The contradicting findings may be due to the broad age range in these study samples, which led to more significant variabilities that washed out the group differences.

Based on the SVR, the decoding skill is foundational for reading to learn. Children with TH who master the decoding skill are not necessarily good at reading comprehension. In addition, those children with $\mathrm{TH}$ who are poor decoders often perform poorly in reading comprehension. Nevertheless, the early decoding skill predicated later reading comprehension in children with TH (Foorman et al., 2018;

Kendeou et al., 2009). Similarly, the decoding skill was also a good predictor for later reading skills in children with Cls (Bell et al., 2019; Mayer, 2007). The decoding skill refers to the process of identifying real words and/or pseudowords timed or untimed (Foorman et al., 2018). If children become more automatic in decoding, they can pay more attention to comprehend what they read. Weisi et al. (2013) found 24 second-grade Persian-speaking children with Cls scored significantly lower on word reading tasks than their hearing peers and failed to gain similar improvement in word reading as their hearing peers in a year. Similarly, Henricson et al. (2012) 33 children with Cls (mean age of 9 years old) scored significantly lower than both 43 children with HAs and 120 children with TH on a word-spotting task during which participants were asked to push a button as soon as they identified a real word among series of nonwords. On the contrary, Nakeva von Mentzer et al. (2013) reported 17 younger children with $\mathrm{Cls}$ (5-7 years old) performed equally to 16 of their hearing peers but scored significantly higher in the letter-naming task than 15 children with HAs. The mixed findings can be due to the variability in hearing loss characteristics among children with HAs and the study sample's age range. 
medRxiv preprint doi: https://doi.org/10.1101/2021.03.02.21252684; this version posted March 27, 2021. The copyright holder for this preprint (which was not certified by peer review) is the author/funder, who has granted medRxiv a license to display the preprint in perpetuity. All rights reserved. No reuse allowed without permission.

Fluency represents the rate, accuracy, and prosody of reading and is identified as a critical component of reading. Fluency has been positively correlated with reading comprehension and is a part of the developmental process of building decoding skill that forms a bridge to reading comprehension in typically developing children (Pikulski \& Chard, 2005; Therrien, 2004). Historically, fluency was a neglected aspect of reading until the early 2000s (National Institute of Child Health and Human Development, 2000). Thus, little research on fluency in children who are DHH is available. The rapid automatized naming (RAN) task provides insight into fluency and predicts later growth in fluency (Lervåg \& Hulme, 2009; Norton \& Wolf, 2012). In this meta-analysis, the RAN task was included as a fluency measure to include more studies possibly. Children with Cls (mean age: 6.8 years) performed equally well in RAN compared to children with TH (Lee et al., 2012; Nittrouer et al., 2012b), whereas children with Cls (age range from 5 to 14 years) performed below their hearing peers in RAN (Bell et al., 2019; Schorr et al., 2008; Soleymani et al., 2016; Weisi et al., 2013). It is unclear to what extent children with Cls differ from their hearing peers and children with HAs in fluency construct.

The ultimate goal of reading for children is to comprehend the written text and successfully transition from learning-to-read to reading-to-learn. If children with Cls lag in foundational skills compared to children with TH or children with HAs, children with Cls are at risk for slow decoding of single words and slow vocabulary learning. Consequently, children with Cls are expected to perform below their hearing peers in reading comprehension tasks. Vermeulen et al. (2007) reported that 50 Dutch children with Cls (mean age of 12.8 years) performed reading comprehension tasks significantly better than 504 deaf Dutch children without Cls and more poorly than 1,475 Dutch children with TH (mean age of 10.1 years) over four grade levels. On average, children with Cls scored -3.6 standard deviation below the norm, which is much better than deaf children without Cls (-7.2 standard deviation below the norm). In addition, $25-50 \%$ of children with $\mathrm{Cls}$ at each grade level scored within or above the 95\% confidence interval of the children with TH. However, a recent review paper evaluated 21 studies 
medRxiv preprint doi: https://doi.org/10.1101/2021.03.02.21252684; this version posted March 27, 2021. The copyright holder for this preprint (which was not certified by peer review) is the author/funder, who has granted medRxiv a license to display the preprint in perpetuity.

All rights reserved. No reuse allowed without permission.

published between 1996-2016 regarding reading comprehension in 1000 children with Cls and summarized that most children with Cls scored within the average range in standardized reading comprehension tests (Mayer \& Trezek, 2018). They also indicated a wide range of variability in performance among children with Cls, but the review paper did not quantitatively synthesize the 21 studies' results.

The current meta-analysis focuses on the above mentioned five constructs, including PA, vocabulary (receptive and expressive), decoding, fluency, and reading comprehension, which were identified as five critical components of reading in children with TH by the report of the National Reading Panel (National Institute of Child Health and Human Development, 2000) and have guided other research (Nation \& Snowling, 2004; Petrill et al., 2006; Pikulski \& Chard, 2005; Silverman et al., 2013; Suggate, 2016; Therrien, 2004). Other factors such as background knowledge, inferencing, executive function, and motivation are also important for reading development, but are beyond this meta-analysis scope.

In summary, previous studies on how children with Cls performed in emergent and later reading skills compared to children with TH and children with HAs have produced mixed findings. QSH suggested that the reading development for children who are $\mathrm{DHH}$ is "qualitatively similar but quantitatively delayed" compared to their hearing peers (Paul, 1998; Trezek et al., 2010). However, it remains unclear to what extent children with Cls differ from children with $\mathrm{TH}$ and children with HAs in emergent and later reading skills. The current meta-analysis aims to quantitatively synthesize studies' results by conducting secondary statistical analyses on reading skills between children with $\mathrm{Cls}$ and children with TH, and between children with Cls and children with HAs. Meta-analysis effectively pools the studies' results to increase statistical power applied to research questions (Hedges et al., 2010).

The conflicting findings and the wide range of score variability in children with Cls can be attributed to considerable differences in participants' age at testing, age at onset of deafness, age at 
medRxiv preprint doi: https://doi.org/10.1101/2021.03.02.21252684; this version posted March 27, 2021. The copyright holder for this preprint (which was not certified by peer review) is the author/funder, who has granted medRxiv a license to display the preprint in perpetuity.

All rights reserved. No reuse allowed without permission.

cochlear implantation, duration of implant use, and percentage of unilateral $\mathrm{Cl}$ users. The five factors may be possible moderators affecting the group differences in reading skills between children with Cls and their hearing peers/children with HAs.

Children with Cls face more challenges in reading over time than their hearing peers (Geers et al., 2008; Sarant et al., 2015). Geers et al. (2008) reported that the reading comprehension gap between children with Cls and their hearing peers increased with age. Van der Kant et al. (2010) also demonstrated that the deviation of a reading comprehension measure from the norm in Flemish and Dutch children with Cls increased with age. In addition, Nittrouer et al. (2018) reported that group differences in PA, vocabulary, and decoding between the $\mathrm{Cl}$ and $\mathrm{HA}$ groups remained somewhat similar across the second and sixth grades. Thus, the gap in reading skills between children with Cls and their hearing peers may widen with age.

Research has shown that children whose deafness occurred postlingually acquired higher speech perception ability than children with prelingual deafness (Ahmad et al., 2012; Buckley \& Tobey, 2011; Busby et al., 1993; Hinderink et al., 1995; Ruff et al., 2017; Seldran et al., 2011). Moreover, deaf children who had normal hearing for even a short period after birth and received a $\mathrm{Cl}$ shortly after losing their hearing had better speech and language proficiency (Geers, 2004; Niparko \& Geers, 2004). Thus, the age at onset of deafness may negatively affect the group difference in reading skills.

The age at implantation is usually negatively correlated with reading skills. Earlier implantation was associated with higher reading skills in children with $\mathrm{Cls}$, and the reading age of children implanted before 42 months matched their chronological age (Archbold et al., 2008). The early implanted $\mathrm{Cl}$ group performed better on vocabulary measures than the later implanted $\mathrm{Cl}$ group (Johnson \& Goswami, 2010). However, Harris et al. (2011) did not find significant decoding differences between an earlyimplanted group and a later-implanted group. The advantage of earlier implantation might stem from a shorter period of auditory deprivation. More extended auditory deprivation could lead to cross-modal 
medRxiv preprint doi: https://doi.org/10.1101/2021.03.02.21252684; this version posted March 27, 2021. The copyright holder for this preprint (which was not certified by peer review) is the author/funder, who has granted medRxiv a license to display the preprint in perpetuity.

All rights reserved. No reuse allowed without permission.

neural plasticity, causing the primary auditory cortex to be used by other sensory inputs (Lazard et al., 2012; Sharma et al., 2009). If a $\mathrm{Cl}$ is received later than 42 months, the benefits are limited (Lazard et al., 2012). Before 42 months, neural plasticity is optimal, and thus a normal range of latency of the first positive peak of the cortical auditory evoked potential post-Cl is achievable (Sharma et al., 2002).

The duration of implant use has also been studied as a possible factor affecting speech recognition outcomes (Dillon et al., 2012; Geers, 2004; Nittrouer et al., 2012b). Studies have identified a positive correlation between implant use duration and phonemic awareness in children with Cls (Dillon et al., 2012; Nittrouer et al., 2012b).

Studies have shown that children who received bilateral Cls performed better in language comprehension, vocabulary, and reading comprehension than children who received a unilateral $\mathrm{Cl}$ (Boons et al., 2012; Ching et al., 2014; Sarant et al., 2015). Bilateral Cls are superior in sound localization and spatial release masking to a unilateral $\mathrm{Cl}$, which should enhance learning the language by helping children hear speech in the environment more efficiently (Boons et al., 2012; Sarant et al., 2015). However, some studies did not find that bilateral Cls significantly benefit language development (Niparko et al., 2010; Nittrouer et al., 2012b). The signal processing is the same for the bilateral Cls, and the acoustic structure that underlies phonemic categories is similarly represented to the brain through both $\mathrm{Cl}$ devices (Nittrouer et al., 2012b). This statement is valid under the circumstance that symmetrical insertion depth between two ears is guaranteed, and there are no frequency-place mismatches between ears through $\mathrm{Cl}$ device programming. Otherwise, the spectral content that is perceived can be different between bilateral $\mathrm{Cls}$ and unilateral $\mathrm{Cl}$. In addition, the differences in neural health patterns between ears before implantation can affect phonemic awareness after implantation. If children had a unilateral $\mathrm{Cl}$ in the ear with poorer neural health and more spectral smearing, the phonemic categories' acoustic structure would not be represented. Thus, the prediction could be made 
medRxiv preprint doi: https://doi.org/10.1101/2021.03.02.21252684; this version posted March 27, 2021. The copyright holder for this preprint (which was not certified by peer review) is the author/funder, who has granted medRxiv a license to display the preprint in perpetuity.

All rights reserved. No reuse allowed without permission.

that the higher percentage of children with a unilateral $\mathrm{Cl}$ will increase the group differences in reading skills between children with $\mathrm{Cls}$ and their hearing peers.

The main objective of the current meta-analysis is to quantitatively summarize the group differences in five constructs (PA, vocabulary, decoding, fluency, and reading comprehension) between children with Cls and their hearing peers and between children with $\mathrm{Cls}$ and children with HAs. The mixed findings in the current literature need to be further analyzed to answer the following questions: (1) do reading skills (a composite of all five constructs) significantly differ between children with Cls as compared to children with TH? (2) do reading skills (a composite of all five constructs) significantly differ between children with Cls as compared to children with HAs? (3) do the group differences between children with Cls as compared to children with TH vary among constructs? (4) do the group differences between children with Cls as compared to children with HAs vary among constructs? (5) does vocabulary domain (receptive versus expressive) alter the magnitude of group differences between children with Cls as compared to children with TH? (6) Does age at testing, age at onset of deafness, age at implantation, duration of implant use, or percentage of unilateral $\mathrm{Cl}$ users significantly relate to the magnitude of group differences between children with $\mathrm{Cls}$ as compared to children with TH?

The present study will quantify the group differences in reading skills between children with Cls and their hearing peers, and between children with $\mathrm{Cls}$ and HAs. Our findings will highlight the scale of reading challenges that children with $\mathrm{Cls}$ face. Children with Cls who are a new generation of children who are DHH benefit from early identification, early treatment, early intervention programs (i.e., speech therapy, parent education), and advances in cochlear implant devices. They attend mainstream education, and their special need for support may be overlooked. Our findings may give educators a better expectation on reading skills for children with $\mathrm{Cls}$ and subsequently provide appropriate interventions to prevent them from falling behind their hearing peers.

\section{Material and Methods}


medRxiv preprint doi: https://doi.org/10.1101/2021.03.02.21252684; this version posted March 27, 2021. The copyright holder for this preprint (which was not certified by peer review) is the author/funder, who has granted medRxiv a license to display the preprint in perpetuity. All rights reserved. No reuse allowed without permission.

\section{Search Strategy}

A Preferred Reporting of Systematic Reviews and Meta-Analyses (PRISMA) flow diagram (Moher et al., 2009) outlined a comprehensive online search. We searched Academic Search Premier, PsycArticles, PsycInfo, ERIC, PubMed, Open Dissertations, ProQuest Dissertations, and Theses Global (Figure 1). Open Dissertations, ProQuest Dissertations, and Theses Global were used to search for unpublished work for minimizing potential publication bias. The titles and abstracts were searched using the following key terms: "hearing loss" OR "cochlear implant" OR "hearing aid" OR "deaf" OR "hard of hearing" and "reading" OR "phonological" OR "phonology" OR "phonemic" OR "word identification" OR "word attack" OR "naming" OR "RAN" OR "vocabulary." Publications after 1990 were included because Cls were not commercially available for children until 1990 in the United States.

The initial search yielded 5,642 articles, and 966 unique abstracts were included for further screening after removing duplications. 858 irrelevant articles were removed, and there were 108 articles left to be further assessed for eligibility.

\section{Study Selection}

The inclusion criteria included: (1) age range from 3 to 18 years old, (2) comparison between individuals with $\mathrm{Cls}$ and those with $\mathrm{TH}$, or comparison between individuals with Cls and those with HAs, (3) measures of reading skills such as phonological processing, word recognition, vocabulary, reading comprehension, fluency, etc. The exclusion criteria were: (1) individuals with no additional disabilities (i.e., Autism Spectrum Disorder, Attention Deficit Hyperactivity Disorder, visual impairment, and cognitive disabilities, etc.) (2) case studies, (3) review articles, (4) written in any languages other than English (not excluded if they were conducted in a language other than English (i.e., 21 of the 41 articles comparing children with Cls to their hearing peers and six of the 15 publications comparing children with Cls to children with HAs were carried out in languages other than English). Some articles that did not include a typical-hearing comparison group or only compared children with Cls to published test norms 
medRxiv preprint doi: https://doi.org/10.1101/2021.03.02.21252684; this version posted March 27, 2021. The copyright holder for this preprint (which was not certified by peer review) is the author/funder, who has granted medRxiv a license to display the preprint in perpetuity.

All rights reserved. No reuse allowed without permission.

were excluded. Missing a comparison group or using test norms does not allow researchers to control other confounders other than chronological age. Meta-analysis uses effect sizes to compare group differences, and effect size cannot be effectively computed without a comparison group. Thus, a comparison group was essential for article inclusion to determine to what extent children with Cls differ from their hearing peers and children with HAs using meta-analysis techniques. Thirteen authors were contacted if articles indicated that needed data were collected but not reported. Three authors responded. For the comparison between $\mathrm{Cl}$ and $\mathrm{TH}$ groups, 41 articles were included. Seven articles reported data from children across different grades. Seven articles were from the same research group and used the same cohorts of children. There were 43 independent samples from 41 articles. For the comparison between $\mathrm{Cl}$ and $\mathrm{HA}$ groups, 15 articles and 19 independent samples were included. There were 9 studies included in both $\mathrm{Cl}$ versus $\mathrm{TH}$ and $\mathrm{Cl}$ versus $\mathrm{HA}$, resulting in 47 articles included in the present study (Figure 1). All 47 articles are listed in Supplementary Table A.2, and all 61 articles excluded due to various reasons are listed in Supplementary Table A.3. In Supplementary Table A.2, the studies conducted in the U.S. reported that most students were in mainstream schools. Most studies indicated their children with $\mathrm{Cl}$ or $\mathrm{HA}$ used oral or total communication mode.

\section{Data Extraction}

The data extracted from each study included participant demographics and psychometric measures of reading skills. Additional data about children who are $\mathrm{DHH}$ were extracted, including the age when hearing loss was identified, level of unaided hearing thresholds, age when Cls were activated or implanted, age when HAs were fitted, duration of Cls/HAs usage, and the percent of participants utilizing a unilateral $\mathrm{Cl}$. For reading skills, we extracted the tasks' names and standardized scores or normalized scores of assessments, and raw scores or percent correct scores if standardized scores were not provided. The reading skills were further categorized into five constructs (Supplementary Table A.2): (1) PA (sound manipulation, i.e., rhyming, elision, first-sound matching, etc.), (2) decoding (visual word 
medRxiv preprint doi: https://doi.org/10.1101/2021.03.02.21252684; this version posted March 27, 2021. The copyright holder for this preprint (which was not certified by peer review) is the author/funder, who has granted medRxiv a license to display the preprint in perpetuity. All rights reserved. No reuse allowed without permission.

recognition, irregular word reading, regular word reading, nonword recognition, etc.), (3) vocabulary (expressive and receptive vocabulary), (4) fluency (reading rate subtest, fluency qualitative reading inventory, and rapid automized naming), (5) reading comprehension (sentence completion, passage comprehension, etc.). The second author coded all studies, and the fourth author independently coded $80 \%$ of the studies. Then, accuracy was calculated by comparing all quantitative information extracted from studies, including moderators and demographics. The overall accuracy of coding demographic information for studies comparing children with Cls with their hearing peers was $94 \%$. The overall accuracy of coding demographic information for studies comparing children with Cls to children with HAs was $96 \%$. The accuracy of the reading skills for studies comparing $\mathrm{Cl}$ and $\mathrm{TH}$ groups was $96 \%$. The accuracy of the reading skills for studies comparing $\mathrm{Cl}$ and $\mathrm{HA}$ groups was $98 \%$. Any discrepancies in the coding were resolved by re-evaluating the full text and discussions between the two coders.

\section{Effect Size Computation}

Hedges' g with bias correction (Hedges, 1981) was used to examine the mean differences in reading skills between groups $(\mathrm{Cl}$ vs. $\mathrm{TH}$, and $\mathrm{Cl}$ vs. $\mathrm{HA})$ because it was recommended for smaller sample sizes $(\mathrm{N}<50)$, and it provided an unbiased and conservative measure. For studies that reported the group differences, we used the reported means and standard deviations to compute the effect-size estimates expressed as Hedges' g. For studies that did not report the group differences directly, t-test statistics between groups were used to compute Hedges' g (Wilson, 2014). The magnitude of standardized mean difference estimates was interpreted based on the following scale (Cohen, 1992): < $.20=$ no effect, $.20-.49=$ small effect, $.50-0.79=$ moderate effect, $\geq 80=$ large effect. Within the study, there were multiple psychometric measures of reading skills that were not from independent samples. Therefore, we used robust variance estimation (RVE) to synthesize Hedges' g without averaging across effect sizes or selecting only one effect size per study (Hedges et al., 2010). Because there were different constructs within the same study sample, we used the correlation weight with 
medRxiv preprint doi: https://doi.org/10.1101/2021.03.02.21252684; this version posted March 27, 2021. The copyright holder for this preprint (which was not certified by peer review) is the author/funder, who has granted medRxiv a license to display the preprint in perpetuity. All rights reserved. No reuse allowed without permission.

moderate $\rho=.40$ to combine effect-size estimates and model the random effects of between-study variance with consideration of correlated constructs from the same study sample (Hedges et al., 2010). The robumeta R package (Fisher et al., 2017) was used for a random-effects model with RVE to examine the magnitude of standardized mean difference estimates. Both $\mathrm{I}^{2}$ and $\tau^{2}$ were calculated to assess the degree of between-study heterogeneity.

\section{Moderator Analyses}

Seven moderators were examined for group comparison between the $\mathrm{Cl}$ and $\mathrm{TH}$ groups, including (1) constructs of reading skills, (2) subtypes of vocabulary, (3) Cl group's age at testing (TH group had matched age at testing), (4) Cl group's age at onset of deafness, (5) Cl group's age at implantation, (6) Cl group's duration of implant use, (7) Cl group's percent of children with unilateral Cl. Only one moderator, constructs of reading skills, was examined for group comparison between the $\mathrm{Cl}$ and HA groups due to the limited number of studies. For the construct moderator, we conducted RVE meta-regression with a small-sample adjusted F-test (Tipton \& Pustejovsky, 2015) to evaluate the potential influence of different moderators on the mean group difference in reading skills using the robumeta (Fisher et al., 2017) and clubSandwich R packages (Pustejovsky, 2017). There were five constructs of reading skills, and we were interested in testing whether the magnitude of standardized mean difference estimates depended on the different constructs of reading skills. Because we were interested in the effect of each construct, we then built random-effects RVE models for each construct separately. There were two subtypes of vocabulary, including receptive and expressive vocabulary. The current meta-analysis also examined whether the group differences between the $\mathrm{Cl}$ and $\mathrm{TH}$ groups depended on the different subtypes of vocabulary (receptive and expressive). The statistical significance level was set at $p<.05$.

\section{Publication Bias and Sensitivity Analysis}


medRxiv preprint doi: https://doi.org/10.1101/2021.03.02.21252684; this version posted March 27, 2021. The copyright holder for this preprint (which was not certified by peer review) is the author/funder, who has granted medRxiv a license to display the preprint in perpetuity. All rights reserved. No reuse allowed without permission.

We searched for unpublished work to reduce potential publication bias. Publication bias is due to the fact that studies with relatively large effect sizes are more likely to be published than studies with smaller effect sizes. In the current meta-analysis, we aggregated effect sizes per each independent sample using the R package MAd (del Re \& Hoyt, 2014). We also generated forest plots and funnel plots of the aggregated effects for visual inspection. To test whether the funnel plot is asymmetric, we used Egger's test (Egger et al., 1997) of standardized mean differences. In addition, if the funnel plot was asymmetric, Rosenthal's Fail-safe $\mathrm{N}$ was computed to check the number of studies needed to nullify the effect (Rosenthal, 1979).

\section{Outlier and Sensitivity Analysis}

We examined potential outliers using an influential study analysis to determine any influential outliers (Viechtbauer \& Cheung, 2010). Additionally, we checked whether the results were affected by different correlation coefficients (e.g., correlation coefficient other than .40) between pairs of effect sizes using the robumeta R package (Fisher et al., 2017).

\section{Results}

\section{Cl versus TH}

\section{Search results and study characteristics}

A total of 41 articles with 43 independent samples and 134 effect sizes were included in comparing $\mathrm{Cl}$ and TH groups (Supplementary Table A.4 and Supplementary Table A.1). The total number of unique participants in the $\mathrm{Cl}$ group was 911 , and the total number of unique participants in the $\mathrm{TH}$ group was 2,438. Supplementary Table A.4 summarizes demographic information, and means were computed from all reported studies.

\section{Group Differences in Reading Skills}

With the RVE random-effects model, the significant effect of the group difference in reading skills between individuals with $\mathrm{Cl}$ and their hearing peers was $-1.14(p<.001,43$ independent samples 
medRxiv preprint doi: https://doi.org/10.1101/2021.03.02.21252684; this version posted March 27, 2021. The copyright holder for this preprint (which was not certified by peer review) is the author/funder, who has granted medRxiv a license to display the preprint in perpetuity. All rights reserved. No reuse allowed without permission.

and 134 effect sizes, 95\% confidence interval [-1.45 -.83]), indicating that the $\mathrm{Cl}$ group scored statistically significantly lower on reading skills than their TH peers. There were substantial levels of between-study heterogeneity $\left(\tau^{2}=.74, I^{2}=89 \%\right)$. Supplementary Table A.5 summarizes the descriptive statistics of each construct. In addition, table 1 summarizes the univariate RVE models for each construct. The significant effect of the group difference in PA between children with Cls and their TH peers was -1.62 ( $p$ $<.001$ ), indicating that the $\mathrm{Cl}$ group scored statistically significantly lower in PA tests than their $\mathrm{TH}$ group. The large effect of the group difference in vocabulary between $\mathrm{Cl}$ and TH was $-1.50(p<.001)$, indicating that the $\mathrm{Cl}$ group scored statistically significantly lower on vocabulary tests than their $\mathrm{TH}$ group. Furthermore, only expressive vocabulary knowledge showed significant group differences between the $\mathrm{Cl}$ and $\mathrm{TH}$ group $(\mathrm{g}=-1.57, \mathrm{p}<.001)$. The group differences in reading comprehension between individuals with $\mathrm{Cl}$ and their TH peers was $-1.39(\mathrm{p}<.001)$, indicating that the $\mathrm{Cl}$ group scored statistically significantly lower in reading comprehension tests than their TH peers. The group differences in decoding between $\mathrm{Cl}$ and TH groups were $-1.24(p<.001)$. The group differences in fluency were not significant, and the $\mathrm{Cl}$ group scored marginally lower in fluency tasks than their $\mathrm{TH}$ peers $(g=-.67, p<.001)$.

\section{Moderators}

Table 2 summarizes the moderator analyses. The construct of reading skills was not a significant moderator for the group differences between $\mathrm{Cl}$ and $\mathrm{TH}(\mathrm{F}=1.76, \mathrm{p}=.192)$, suggesting that the magnitude of standardized mean difference estimates between $\mathrm{Cl}$ and $\mathrm{TH}$ groups were not affected by the type of constructs of reading skills. The vocabulary subtype was a significant moderator for the group differences between $\mathrm{Cl}$ and $\mathrm{TH}(\mathrm{F}=15.4, \mathrm{p}=.015)$, indicating that the magnitude of standardized mean difference estimates between $\mathrm{Cl}$ and $\mathrm{TH}$ groups were affected by the subtype of vocabulary knowledge. The $\mathrm{Cl}$ group's age at testing, age at onset of deafness, age at implantation, and implant use duration were not significant moderators for the group differences between $\mathrm{Cl}$ and $\mathrm{TH}$ (Table 2). The $\mathrm{Cl}$ 
medRxiv preprint doi: https://doi.org/10.1101/2021.03.02.21252684; this version posted March 27, 2021. The copyright holder for this preprint (which was not certified by peer review) is the author/funder, who has granted medRxiv a license to display the preprint in perpetuity. All rights reserved. No reuse allowed without permission.

group's percent of children with unilateral $\mathrm{Cl}$ was a significant moderator for group differences between $\mathrm{Cl}$ and $\mathrm{TH}(\mathrm{p}=.008)$, indicating more children with unilateral $\mathrm{Cl}$ in the $\mathrm{Cl}$ group negatively impacted the group differences between $\mathrm{Cl}$ and $\mathrm{TH}$.

\section{Publication bias}

Studies with significant findings, large effects, or large sample sizes were more likely to be published (Hedges, 1989). If the effect size is big, a result is more likely to become statistically significant for any sample size. Particularly for small sample sizes, very large effect sizes are needed to reach statistical significance. We searched the unpublished work and tried to minimize publication bias. We generated both a forest plot (Supplementary Figure A.1) and a funnel plot (Supplementary Figure A.3). The funnel plot indicated a slight asymmetry, with a majority of the smaller studies clustering to the left of the mean. The visual impression is confirmed by Egger's test, which showed a statistically significant asymmetry in the funnel plot $(t=-7.24, p<.001)$, suggesting the presence of small-study effects. As a whole, the smaller sample-size studies did tend to report a large group difference between children with Cls and their TH peers (see the forest plot in Supplementary Figure A.1). Rosenthal's Fail-safe N was 76,363 , suggesting that there would need to be 76,363 studies added to the current meta-analysis before the cumulative effect would become statistically non-significant. Given that this meta-analysis identified only 41 articles that met the inclusion criteria, it is unlikely that nearly 76,363 studies were missed. While we may have overstated the group differences in reading skills between children with $\mathrm{Cls}$ and their TH peers, it is unlikely that the actual group difference is zero.

\section{Outliers and sensitivity}

There were three influential cases (Rezaei et al., 2016; Soleymani et al., 2016; Weisi et al., 2013). But the removal of these three influential cases did not affect the statistical inference of the large effect of group differences in reading skills $(g=-1.08, p<.001,95 \%$ confidence interval $[-1.36,-.81])$, or the results of moderator analyses and publication bias analysis. Therefore, we included all the effect sizes in 
medRxiv preprint doi: https://doi.org/10.1101/2021.03.02.21252684; this version posted March 27, 2021. The copyright holder for this preprint (which was not certified by peer review) is the author/funder, who has granted medRxiv a license to display the preprint in perpetuity. All rights reserved. No reuse allowed without permission.

the current meta-analysis of group differences in reading skills between $\mathrm{Cl}$ and $\mathrm{TH}$. In addition, the large effect of the group differences in reading skills between individuals with Cls and their TH peers did not change when degrees of correlations varied from 0 to 1 (e.g., $0, .20, .40, .60, .80$, and 1.00).

\section{$\mathrm{Cl}$ versus $\mathrm{HA}$}

\section{Search results and study characteristics}

A total of 15 articles with 19 independent samples, and 59 effect sizes were included in the comparison between $\mathrm{Cl}$ and $\mathrm{HA}$ groups (Supplementary Table A.6 and Supplementary Table A.1). The total number of unique participants in the $\mathrm{Cl}$ group was 448 , and the total number of unique participants in the HA group was 434. Supplementary Table A.6 summarizes demographic information and means computed from all reported studies.

\section{Group Differences in Reading Skills}

With the RVE random-effects model, the small effect of the group differences in reading skills between children with Cls and children with HAs was -.04 ( $p=.726,59$ effect sizes, 95\% confidence interval [-.25 -.17]), indicating that there were no statistically significant differences between $\mathrm{Cl}$ and $\mathrm{HA}$ groups in reading skills. There were moderate levels of between-study heterogeneity $\left(\tau^{2}=.15, I^{2}=\right.$ 61\%). In addition, table 3 summarizes the RVE models for each construct. The group difference in PA between $\mathrm{Cl}$ and HA was - .30 ( $p=.028,13$ effect sizes, 95\% confidence interval [-.55 -.06]), indicating that the $\mathrm{Cl}$ group scored statistically significantly lower on PA tests than the HA group. The group differences associated with vocabulary, decoding, fluency, and reading comprehension were $-.08(p=$ $0.692),-.24(p=.179),-.24$, and $.08(p=.568)$, respectively. The group differences in vocabulary, decoding, fluency, and reading comprehension between children with Cls and children with HAs were not statistically significant.

\section{Moderator}


medRxiv preprint doi: https://doi.org/10.1101/2021.03.02.21252684; this version posted March 27, 2021. The copyright holder for this preprint (which was not certified by peer review) is the author/funder, who has granted medRxiv a license to display the preprint in perpetuity. All rights reserved. No reuse allowed without permission.

Due to the small number of studies included in this meta-analysis, only one moderator (constructs of reading skills) was examined. The construct of reading skills was not a statistically significant moderator for the group differences between $\mathrm{Cl}$ and $\mathrm{HA}(\mathrm{F}=2.38, \mathrm{p}=.127)$.

\section{Publication bias}

To assess publication bias, we generated a forest plot (see Supplementary Figure A.2) and a funnel plot (see Supplementary Figure A.4). The Egger's test of asymmetry was not significant $(\mathrm{t}=-.51 \mathrm{p}$ $=.611$ ), indicating no significant publication bias. Since Egger's test was not significant, Rosenthal's Failsafe $\mathrm{N}$ was not computed.

\section{Outlier and Sensitivity Analyses}

There was one influential case (Henricson et al., 2012). The influential case did not affect the statistical inference of the group differences in reading skills $(g=-.02, p=.806,95 \%$ confidence interval $[-.22, .17])$ or the results of publication bias analysis and moderator analyses. Therefore, we included all the effect sizes in the current meta-analysis. Additionally, the group difference in reading skills between $\mathrm{Cl}$ and $\mathrm{HA}$ did not change when degrees of correlations varied from 0 to 1.

\section{Discussion}

The current study is the first comprehensive and quantitative meta-analysis to pool effect sizes of reading skills between children with $\mathrm{Cls}$ and their hearing peers, and between children with $\mathrm{Cls}$ and children with HAs. The current meta-analysis systematically examined to what extent children with Cls differ in reading tests than their hearing peers or children with HAs. Findings from this meta-analysis provide rigorous insights regarding group differences $(\mathrm{Cl}$ versus $\mathrm{TH}$ and $\mathrm{Cl}$ versus $\mathrm{HA})$ on test performance measuring emergent and later reading skills, which have implications not only for informing educators what to expect for children with Cls when it comes to emergent and later reading skills, but also for better understanding of reading challenges for children who are $\mathrm{DHH}$. 
medRxiv preprint doi: https://doi.org/10.1101/2021.03.02.21252684; this version posted March 27, 2021. The copyright holder for this preprint (which was not certified by peer review) is the author/funder, who has granted medRxiv a license to display the preprint in perpetuity. All rights reserved. No reuse allowed without permission.

Overall, when five constructs (PA, vocabulary, decoding, fluency, and reading comprehension) were included in the RVE random-effect model (a total of 134 effect sizes included), there was a significant large effect of group differences between children with $\mathrm{Cls}$ and their hearing peers. On average, children with Cls scored significantly lower than their hearing peers, but the large effect only indicated children with Cls performed one standard deviation (SD) below their hearing peers on tests measuring their emergent and reading skills. This result aligns with those studies reporting that children with Cls scored significantly lower than their hearing peers, but still achieved within the normal range on reading tests (i.e., out of normal range is defined as more than 1.5 SD or more below the norm) (Dillon et al., 2012; Spencer et al., 2003). While the construct of reading skills did not significantly change the magnitude of the group differences between children with $\mathrm{Cls}$ and their hearing peers, our results also indicated children with Cls struggled more in PA, vocabulary, and reading comprehension and less in decoding and fluency. Our findings align with the QSH (Paul \& Alqraini, 2019) and suggest that similar to their hearing peers, children with Cls require the same foundational skills to learn to read. The average performance among children with Cls in reading skills in the current meta-analysis is encouraging and confirms a positive shift in reading outcomes for profoundly deaf children as a consequence of cochlear implantation despite the poor scores in all constructs. Although there is variability among constructs of reading skills, overall reading outcomes exceed the historically reported 4th-grade ceiling (Paul \& Alqraini, 2019). Notably, some children with Cls performed on reading tests at an age-appropriate level, consistent with a recent review paper on literacy outcomes that suggested an incredible improvement with many students with Cls achieving reading outcomes at the age-appropriate range (Mayer \& Trezek, 2018). Our findings highlight the scales of difficulties in each construct of reading skills faced by children with $\mathrm{Cls}$ and provide a rationale for early intervention for children with Cls to develop foundational reading skills (Lederberg et al., 2014). 
medRxiv preprint doi: https://doi.org/10.1101/2021.03.02.21252684; this version posted March 27, 2021. The copyright holder for this preprint (which was not certified by peer review) is the author/funder, who has granted medRxiv a license to display the preprint in perpetuity. All rights reserved. No reuse allowed without permission.

The findings concerning group differences between children with Cls and children with HAs are less robust due to a limited number of articles included in the current meta-analysis (15 articles, 19 independent samples, and 59 effect sizes). For PA construct only, there was a small effect of group difference between children with Cls and children with HAs, in agreement with those studies reporting children with moderately severe and severe hearing loss who used HAs performed better in PA than children with profound hearing loss who received Cls (Fitzpatrick et al., 2012). In addition, PA intervention studies demonstrated that both children with Cls and children with HAs improved phonological skills after the intervention, and PA intervention given to children with hearing loss who wear $\mathrm{Cls}$ and/or HAs during their pre-kindergarten school year equipped them to enter kindergarten with PA skills that generally exceeded minimal entry-level expectations for their hearing peers (Sohail \& Nabeel, 2019; Werfel et al., 2016). Therefore, there is a strong rationale for providing early intervention to children who are DHH with functional hearing for the development of their foundational reading skills (Lederberg et al., 2014).

Emergent reading skills start before PA when young children are surrounded by environmental print (Neumann et al., 2012). In pre-kindergarten and kindergarten, instruction emphasizes phonemes, oral language, and some letter-to-sound knowledge (Shanahan \& Lonigan, 2010). The largest effects of group differences between children with $\mathrm{Cls}$ and their hearing peers and between children with $\mathrm{Cls}$ and children with HAs were found in the PA construct. The poor performance in PA is a consequence of impoverished and degraded auditory inputs through Cls, aligned with other studies (Ambrose et al., 2012; Rastegarianzadeh et al., 2014). In the current study, the construct of PA consisted of syllable deletion, syllable counting, initial/final consonant discrimination, phoneme deletion, elision, blending, segmenting, and rhyme tasks. The $95 \%$ confidence interval for PA was wide and can be accounted for in various PA tasks included. Children with Cls (mean age: 8.33 years old) performed better on the syllable test than the rhyme test and better on the rhyme test than the phoneme test (James et al., 2005). 
medRxiv preprint doi: https://doi.org/10.1101/2021.03.02.21252684; this version posted March 27, 2021. The copyright holder for this preprint (which was not certified by peer review) is the author/funder, who has granted medRxiv a license to display the preprint in perpetuity.

All rights reserved. No reuse allowed without permission.

Children with Cls (mean age: 8.58 years old) scored significantly lower on initial and final phoneme decision tasks than their hearing peers, but not on syllable counting task (Nittrouer et al., 2016a). The Cls provide relatively degraded spectral information and cannot fully normalize a child's auditory experience. Thus, compared to children with $\mathrm{TH}$, children with $\mathrm{Cls}$ experience lower phonological sensitivity (Eisenberg et al., 2004; Harlan et al., 2007; Wei et al., 2004), and delayed speech and language development (Geers et al., 2008; Nittrouer \& Caldwell-Tarr, 2016c). Our meta-analysis also demonstrated that children with HAs outperformed children with Cls in the PA tasks less than one standard deviation. Children with HAs exhibit mild to severe hearing loss, while children with Cls exhibit severe to profound hearing loss. The two groups usually consist of heterogeneous cohorts with unmatched hearing profiles (i.e., unaided hearing level, unilateral versus bilateral).

The group difference in vocabulary between children with $\mathrm{Cls}$ and their hearing peers was second among all five constructs. The current meta-analysis examined 29 independent samples and found that children with Cls scored 1.5 SD below their hearing peers on vocabulary tasks. Moreover, lower performance in PA tasks in children with Cls could affect vocabulary development. Children with Cls took significantly more days to acquire their first 100 words than their hearing peers (Nott et al., 2009). Meanwhile, the lag in vocabulary in children with Cls could also affect the development of phonological representations according to the lexical restructuring model (Metsala \& Walley, 1998). The magnitude of group differences varied across studies that were included in the current meta-analysis. However, children with Cls always performed more poorly on vocabulary tasks than their hearing peers regardless of different types of psychometric tests used to measure vocabulary knowledge, which is in agreement with a recent meta-analysis comparing vocabulary knowledge in children with Cls aged 49 to 109 months versus their hearing peers (Lund, 2016). Lund et al. (2016) evaluated 12 articles using forest plots and found that children with Cls performed more poorly than their hearing peers in both receptive (-.46 to -2.00$)$ and expressive vocabulary (-.34 to -1.06$)$ (Lund, 2016). In addition, we found no significant 
medRxiv preprint doi: https://doi.org/10.1101/2021.03.02.21252684; this version posted March 27, 2021. The copyright holder for this preprint (which was not certified by peer review) is the author/funder, who has granted medRxiv a license to display the preprint in perpetuity. All rights reserved. No reuse allowed without permission.

group difference in vocabulary knowledge between children with Cls and children with HAs, which can be due to the heterogeneity of hearing loss profiles between the two groups.

The difference between receptive and expressive vocabulary in the current meta-analysis reached statistical significance, contrary to the recent meta-analysis (Lund, 2016). The present metaanalysis indicated that expressive vocabulary was more delayed for children with Cls than their hearing peers. The current study found that children with Cls scored 1.6 SD below their hearing peers on expressive vocabulary and .4 SD below their hearing peers on receptive vocabulary. However, Lund et al. (2016) demonstrated that children with Cls scored 20.33 points lower on measures of receptive vocabulary and 11.99 points lower on measures of expressive vocabulary than their hearing peers. The discrepancy can be due to the use of raw scores versus norm-referenced or normalized scores of assessments, and the number of different studies included in each study. Lund et al. (2016) mentioned that more studies would have increased the likelihood of a significant difference between receptive and expressive vocabulary knowledge. The current study included more studies on expressive vocabulary, not on receptive vocabulary. Due to the unbalanced number of studies between receptive ( 7 effect sizes) and expressive (31 effect sizes) vocabulary knowledge in the current study, poorer expressive vocabulary may reflect properties of a test rather than a quantitative difference in vocabulary knowledge.

The group difference in decoding between children with $\mathrm{Cls}$ and their hearing peers was slightly smaller than PA and vocabulary constructs. There was no significant difference in decoding between children with Cls and children with HAs. In the current meta-analysis, decoding included some tasks that require reading words covertly and other tasks that require reading words overtly. For reading words covertly, children with Cls could use strategies other than phonological coding strategies to recognize words visually. For reading words overtly, children with Cls had to use phonological coding strategies to produce words overtly. Thus, the alternative strategies in word-level decoding led to more minor group 
medRxiv preprint doi: https://doi.org/10.1101/2021.03.02.21252684; this version posted March 27, 2021. The copyright holder for this preprint (which was not certified by peer review) is the author/funder, who has granted medRxiv a license to display the preprint in perpetuity. All rights reserved. No reuse allowed without permission.

differences between children with $\mathrm{Cls}$ and their hearing peers. Phonological coding strategies for wordlevel decoding are essential for skilled reading (Bell et al., 2019; Geers, 2003; Watson, 2002), but other visual strategies through semantic cues might help to decode.

The current meta-analysis did not find significant group differences in fluency tasks between children with Cls and their hearing peers, and between children with $\mathrm{Cls}$ and children with HAs. But these findings are less robust due in part to the fact that there is a lack of literature on fluency in children who are $\mathrm{DHH}$, with only 8 effect sizes for $\mathrm{Cl}$ versus $\mathrm{TH}$ groups and 2 effect sizes for $\mathrm{Cl}$ versus HAs. In addition, the RAN task was included in the construct of fluency since researchers suggested that RAN is an early indicator that predicts reading fluency (Norton \& Wolf, 2012). There were mixed findings in the studies included in the current meta-analysis, which may contribute to the non-significant group differences. Some studies found that children with Cls performed as well as their hearing peers in RAN tasks (Lee et al., 2012; Nittrouer, Caldwell, \& Holloman, 2012a), whereas other studies identified significantly lower performance in RAN tasks for children with Cls than their hearing peers (Bell et al., 2019; Schorr et al., 2008). The mixed results could be attributed to different types of RAN tasks. In general, children learned to name colors and objects first, then numbers and letters (Denckla \& Rudel, 1974). For example, Bell et al. (2019) required children with Cls to name letters or numbers, whereas Lee et al. (2012) and Nittrouer et al. (2012a) asked children with Cls to name colors and objects. The current meta-analysis identified that children with Cls performed 1.39 SD below their hearing peers on reading comprehension tasks. There was no significant difference in reading comprehension between children with $\mathrm{Cls}$ and children with HAs. Based on the SVR model (Gough \& Tunmer, 1986), it is expected for children with Cls to have lower performance on reading comprehension due to poorer decoding and linguistic comprehension (vocabulary) skills. The cloze tasks used to measure reading comprehension require children to know the syntactic structure of language. Since children with Cls lagged behind their hearing peers in grammatical abilities (Nittrouer et al., 2014; 
medRxiv preprint doi: https://doi.org/10.1101/2021.03.02.21252684; this version posted March 27, 2021. The copyright holder for this preprint (which was not certified by peer review) is the author/funder, who has granted medRxiv a license to display the preprint in perpetuity. All rights reserved. No reuse allowed without permission.

Schorr et al., 2008) and morphosyntactic abilities (Nittrouer et al., 2018), children with Cls would make more mistakes due to a possible deficiency in understanding syntactic structure during cloze tasks. Notably, the large effect of group difference in reading comprehension demonstrated that children with Cls scored 1.39 SD below their hearing peers, within the normal range. This finding agrees with the positive shift in reading outcomes described in a recent review article (Mayer \& Trezek, 2018).

Further analysis reveals that the magnitude of difference in emergent and later reading skills between children with $\mathrm{Cls}$ and their hearing peers does not significantly relate to chronological age at testing, age at onset of deafness, age at implantation, and implant use duration. We hypothesized that group differences in reading skills between children with $\mathrm{Cls}$ and their hearing peers would increase. Because the Matthew effect in reading suggested that reading ability gaps increase with age because the poor pre-reading skills can lead to less reading experience that negatively impacts the reading ability (Stanovich, 1986). In addition, previous literature suggested that students with Cls experience a gap in reading that increases as they get older (Geers \& Hayes, 2011; van der Kant et al., 2010). However, the current meta-analysis did not find a significant effect of chronological age at testing on group differences, which can be due to the use of mean age and norm-referenced or normalized scores of assessments in most studies included in the present meta-analysis. The mean age of the $\mathrm{Cl}$ group was used to represent the whole comparison groups' mean age because studies used the age-matched controls. Some studies had a small age range within each group (Ambrose, 2009; Nittrouer, 2016a; Rezaei et al., 2016; Weisi et al., 2013), whereas other studies included a wide age range within each group (Henricson et al., 2012; Schorr et al., 2008; Wass et al., 2008). Thus, using the Cl group's mean age might not accurately represent the age range included in all the studies. Further, norm-referenced scores can reduce the effect size (Lund, 2016), leading to low sensitivity for detecting the age effect. Lund et al. (2016) also reported that the age at testing was not significantly related to the magnitude of group differences for vocabulary knowledge. Nittrouer et al. (2018) reported no significant increases in 
medRxiv preprint doi: https://doi.org/10.1101/2021.03.02.21252684; this version posted March 27, 2021. The copyright holder for this preprint (which was not certified by peer review) is the author/funder, who has granted medRxiv a license to display the preprint in perpetuity. All rights reserved. No reuse allowed without permission.

group differences between children with $\mathrm{Cls}$ and their hearing peers in PA, decoding, and expressive vocabulary from second grade to sixth grade. Another study, however, reported that children with Cls started with lower scores in receptive vocabulary compared to their hearing peers, and they made enough progress yearly to reduce the gap over three years (Hayes et al., 2009). The heterogeneity between participants makes it harder to detect longitudinal changes using a cross-sectional approach. Thus, longitudinal studies are better suited to address developmental aspects of group differences between children with Cls with their hearing peers, and between children with Cls with children with HAs.

Geers (2003) found the later onset of deafness (between birth and 36 months) was associated with better reading competence. Dillon et al. (2006) also suggested that children who were not congenitally deaf performed better than children who were congenitally deaf in PA tasks. They included a wide range of ages at onset of deafness (mean \pm SD: $2.3 \pm 6.4$, range from $0-36$ months). However, the current meta-analysis evaluated 27 independent samples (71 effect sizes) that included a narrow range of age at onset of deafness (mean \pm SD: $9.8 \pm 2.7$, range from $4-17$ months). Our findings aligned with Lund et al. (2016) and Vermeulen et al. (2007), reporting that the age at onset of deafness had no significant effect on reading skills.

Several studies have reported a positive impact of age at implantation on reading skills (Archbold et al., 2008; Gallego et al., 2016; Johnson \& Goswami, 2010; Mayer et al., 2016; Nittrouer et al., 2012b). Being implanted earlier in life was associated with better PA and linguistic comprehension (Nittrouer et al., 2012b). Despite many benefits of early implantation, children with Cls, regardless of age at implantation, continue to have difficulties with grammatical comprehension than their hearing peers (Gallego et al., 2016). Especially when cognitive processing demands increased, children with Cls performed more poorly than their hearing peers, which kept them from reaching a normalized reading comprehension level in most cases (Gallego et al., 2016). All those studies divided children with Cls into 
medRxiv preprint doi: https://doi.org/10.1101/2021.03.02.21252684; this version posted March 27, 2021. The copyright holder for this preprint (which was not certified by peer review) is the author/funder, who has granted medRxiv a license to display the preprint in perpetuity. All rights reserved. No reuse allowed without permission.

early-implantation and late-implantation groups. However, the current meta-analysis used age at implantation as a continuous variable (mean \pm SD: $31.8 \pm 18.1$, range: $14.7-99.5$ months) and might not be sensitive to capturing the effect of age at implantation on group differences in reading skills between children with $\mathrm{Cls}$ and their hearing peers. Our findings are aligned with some studies reporting that the age at implantation did not significantly affect PA, vocabulary, and decoding (Ambrose, 2009; Lund, 2016; Wass et al., 2008) and a recent review article (Mayer \& Trezek, 2018).

The percent of children who used a unilateral $\mathrm{Cl}$ in the study cohort was the only significant moderator. Findings from the current meta-analysis demonstrated that a higher percentage of children with a unilateral $\mathrm{Cl}$ in the study cohort was associated with more substantial group differences in reading skills between the $\mathrm{Cl}$ and $\mathrm{TH}$ groups, suggesting bilateral implantation has more benefits for reading skills than unilateral implantation. Bilateral implantation has been reported to have a positive effect on PA, linguistic comprehension, receptive vocabulary, and rate of vocabulary development, where children with bilateral Cls outperformed children with a unilateral $\mathrm{Cl}$ (Boons et al., 2012; Caselli et al., 2012; Guerzoni et al., 2020; Sarant et al., 2014; Sparreboom et al., 2015). Additionally, children with a unilateral $\mathrm{Cl}$ and a contralateral $\mathrm{HA}$ performed more poorly in reading comprehension tasks than children with bilateral Cls (Guerzoni et al., 2020). The benefits of bilateral implantation can be affected by several factors, such as whether the implants were received simultaneously or sequentially, the interimplant interval length if they were sequential, and the age when the first and second implants were received. Simultaneous bilateral implantation and short inter-implant intervals were significantly associated with better speech perception outcomes (Gordon \& Papsin, 2009). Longer inter-implant intervals increased the chance of not using the second implant regularly to maximize the benefits of bilateral implantation (Low et al., 2020). In addition, children with unilateral $\mathrm{Cl}$ and $\mathrm{HA}$ in the other better ear who experienced early bimodal stimulation had better PA skills than children with bilateral Cls 
medRxiv preprint doi: https://doi.org/10.1101/2021.03.02.21252684; this version posted March 27, 2021. The copyright holder for this preprint (which was not certified by peer review) is the author/funder, who has granted medRxiv a license to display the preprint in perpetuity. All rights reserved. No reuse allowed without permission.

(Nittrouer et al., 2018). Children with bilateral Cls or children who experience bimodal stimulation had a better chance of developing good speech perception skills (de Raeve et al., 2015).

\section{Limitations and Future Directions}

There are several limitations to the current meta-analysis. First, the limited amount of information available about socioeconomic status, home literacy environment, and nonverbal cognition constrain the moderator analysis in the present study. These factors, including socioeconomic status, home literacy environment, and nonverbal cognition, have been related to reading development for both $\mathrm{Cl}$ and TH groups (Traxler, 2017). Group differences in reading skills may result, wholly or partly, from different early language and reading experiences at home, and from how children were taught to read in school. Future work may consider these factors in a correlational meta-analysis. In addition, future studies need to include more detailed information about the characteristics of hearing loss, environmental factors, and early interventions received (e.g., whether sign language was used before cochlear implantation). These factors are essential to resolve the discrepancy among studies in the current literature. Second, both published and unpublished studies were included in the present study to minimize publication bias. The asymmetric funnel plot for comparison between $\mathrm{Cl}$ and $\mathrm{TH}$ groups indicated the presence of small-study effects. Although Rosenthal's Fail-safe N suggested that it is unlikely that the actual group difference is zero, the magnitude of standardized mean difference estimates might be overstated for comparison between $\mathrm{Cl}$ and $\mathrm{TH}$ groups. Third, the number of studies included in the meta-analysis of group differences between children with Cls and children with HAs was relatively small. Very few studies compared reading skills between the $\mathrm{Cl}$ and $\mathrm{HA}$ groups. Moreover, not all studies reported information regarding the characteristics of hearing loss for each group. Thus, there was not enough data to conduct the same moderator analysis to compare the $\mathrm{Cl}$ and $\mathrm{HA}$ groups. Finally, given the limited research available, 21 articles comparing children with Cls to their hearing peers and six articles comparing children with Cls to children with HAs were carried out in language (i.e., Swedish, 
medRxiv preprint doi: https://doi.org/10.1101/2021.03.02.21252684; this version posted March 27, 2021. The copyright holder for this preprint (which was not certified by peer review) is the author/funder, who has granted medRxiv a license to display the preprint in perpetuity. All rights reserved. No reuse allowed without permission.

French, German, Dutch, Spanish, Farsi, Turkish, Persian, Hindi, Korean, Chinese) other than English were not excluded in the current meta-analysis (see Supplementary Table A.2), which might introduce more variance in effect sizes. Chinese is a logographic writing system that is different from English using an alphabetical system. Better PA in Chinese readers has been significantly correlated to better Chinese word recognition (Huang \& Hanley, 1995). Within 41 articles comparing children with Cls to their hearing peers, one study (Tse \& So, 2012) conducted PA tasks in Cantonese (effect size range from .008 - -.538, see Supplementary Figure A.1) and is unlikely to affect the overall effect size for PA ( $g=-1.62)$. Despite these limitations, the current meta-analysis highlights the positive shift in reading skills for the newer generation of children with Cls, even though the use of $\mathrm{Cls}$ did not normalize PA, vocabulary, decoding, fluency, and reading comprehension skills for children with Cls. Since most children with Cls in the U.S. are mainstreamed (Vatalaro et al., 2018), reading challenges in children with Cls might be overlooked. Educators need to be mindful that some children with Cls may need additional support in the early intervention and educational settings. Future studies can focus on designing appropriate reading assessments and evaluating the effects of code-based or meaning-based intervention for children who are $\mathrm{DHH}$. 
medRxiv preprint doi: https://doi.org/10.1101/2021.03.02.21252684; this version posted March 27, 2021. The copyright holder for this preprint

(which was not certified by peer review) is the author/funder, who has granted medRxiv a license to display the preprint in perpetuity.

All rights reserved. No reuse allowed without permission.

\section{References}

* marked articles that are included in the quantitative meta-analysis and a full list of all articles that included in the meta-analysis can be found in the Supplementary Document.

Ahmad, F. I., Demason, C. E., Teagle, H. F. B., Henderson, L., Adunka, O. F., \& Buchman, C. A. (2012). Cochlear implantation in children with postlingual hearing loss. Laryngoscope, 122(8), 1852-1857. https://doi.org/10.1002/lary.23362

*Ambrose, S. E. (2009). Phonological awareness development of preschool children with cochlear implants (Order No. 854555347) [Doctoral disertation, University of Kansas]. ProQuest Dissertations and Theses Global.

Ambrose, Sophie E., Fey, M. E., \& Eisenberg, L. S. (2012). Phonological awareness and print knowledge of preschool children with cochlear implants. Journal of Speech, Language, and Hearing Research, 55(3), 811-823. https://doi.org/10.1044/1092-4388(2011/11-0086)

Archbold, S., Harris, M., O’Donoghue, G., Nikolopoulos, T., White, A., \& Lloyd Richmond, H. (2008). Reading abilities after cochlear implantation: The effect of age at implantation on outcomes at 5 and 7 years after implantation. Int J Pediatr Otorhinolaryngol, 72(10), 1471-1478. https://doi.org/10.1016/j.ijporl.2008.06.016

*Bell, N., Angwin, A. J., Wilson, W. J., \& Arnott, W. L. (2019). Reading development in children with cochlear implants who communicate via spoken language: A psycholinguistic investigation. Journal of Speech, Language, and Hearing Research, 62(2), 456-469. https://doi.org/10.1044/2018_JSLHRH-17-0469

Blamey, P., Barry, J., Bow, C., Sarant, J., Paatsch, L., \& Wales, R. (2001). The development of speech production following cochlear implantation. Clinical Linguistics and Phonetics, 15(5), 363-382. https://doi.org/10.1080/02699200010017823

Boons, T., Brokx, J. P. L., Frijns, J. H. M., Peeraer, L., Philips, B., Vermeulen, A., Wouters, J., \& Van 
medRxiv preprint doi: https://doi.org/10.1101/2021.03.02.21252684; this version posted March 27, 2021. The copyright holder for this preprint (which was not certified by peer review) is the author/funder, who has granted medRxiv a license to display the preprint in perpetuity. All rights reserved. No reuse allowed without permission.

Wieringen, A. (2012). Effect of pediatric bilateral cochlear implantation on language development. Archives of Pediatrics \& Adolescent Medicine, 166(1), 28-34.

Buckley, K. A., \& Tobey, E. A. (2011). Cross-Modal Plasticity and Speech Perception in Pre- and Postlingually Deaf Cochlear Implant Users. Ear and Hearing, 32(1). https://journals.Iww.com/earhearing/Fulltext/2011/02000/Cross_Modal_Plasticity_and_Speech_Perception_in.2.aspx

Busby, P. A., Tong, Y. C., \& Clark, G. M. (1993). Electrode position, repetition rate, and speech perception by early- and late-deafened cochlear implant patients. The Journal of the Acoustical Society of America, 93(2), 1058-1067. https://doi.org/10.1121/1.405554

Butler, S. R., Marsh, H. W., Sheppard, M. J., \& Sheppard, J. L. (1985). Seven-year longitudinal study of the early prediction of reading achievement. Journal of Educational Psychology, 77(3), 349-361. https://doi.org/10.1037/0022-0663.77.3.349

*Caselli, M. C., Rinaldi, P., Varuzza, C., Giuliani, A., Burdo, S., Cristina, C. M., Pasquale, R., Cristiana, V., Anna, G., Sandro, B., Caselli, M. C., Rinaldi, P., Varuzza, C., Giuliani, A., Burdo, S., Cristina, C. M., Pasquale, R., Cristiana, V., Anna, G., \& Sandro, B. (2012). Cochlear Implant in the Second Year of Life: Lexical and Grammatical Outcomes. Journal of Speech, Language, and Hearing Research, 55(2), 382-394. https://doi.org/10.1044/1092-4388(2011/10-0248)

CDC. (2017). Data and Statistics About Hearing Loss in Children.

https://www.cdc.gov/ncbddd/hearingloss/data.html

Ching, T. Y. C., Day, J., Van Buynder, P., Hou, S., Zhang, V., Seeto, M., Burns, L., \& Flynn, C. (2014). Language and speech perception of young children with bimodal fitting or bilateral cochlear implants. Cochlear Implants International, 15(sup1), S43-S46.

Cohen, J. (1992). A power primer. Psychol Bull, 112(1), 155-159.

https://www.ncbi.nlm.nih.gov/pubmed/19565683

Connor, C. M., Alberto, P. A., Compton, D. L., \& O'Connor, R. E. (2014). Improving outcomes for students 
medRxiv preprint doi: https://doi.org/10.1101/2021.03.02.21252684; this version posted March 27, 2021. The copyright holder for this preprint

(which was not certified by peer review) is the author/funder, who has granted medRxiv a license to display the preprint in perpetuity.

All rights reserved. No reuse allowed without permission.

with or at risk for reading disabilities. In Improving Outcomes for Students with or at Risk for Reading Disabilities.

de Raeve, L., Vermeulen, A., \& Snik, A. (2015). Verbal cognition in deaf children using cochlear implants:

Effect of unilateral and bilateral stimulation. Audiology \& Neurotology, 20(4), 261-266.

https://doi.org/10.1159/000381003

del Re, A. C., \& Hoyt, W. T. (2014). MAd: Meta-analysis with mean differences. R Package Version 0.8-2.

URL Http://Cran. r-Project. Org/Web/Packages/MAd.

Denckla, M. B., \& Rudel, R. (1974). Rapid "automatized" naming of pictured objects, colors, letters and numbers by normal children. Cortex, 10(2), 186-202.

Dillon, C. M., de Jong, K., \& Pisoni, D. B. (2012). Phonological awareness, reading skills, and vocabulary knowledge in children who use cochlear implants. J Deaf Stud Deaf Educ, 17(2), 205-226.

https://doi.org/10.1093/deafed/enr043

Easterbrooks, S. R., Lederberg, A. R., Miller, E. M., Bergeron, J. P., \& McDonald Connor, C. (2008).

Emergent literacy skills during early childhood in children with hearing loss: Strengths and weaknesses. Volta Review, 108(2), 91-114. https://doi.org/10.17955/tvr.108.2.608

Egger, M., Smith, G. D., Schneider, M., \& Minder, C. (1997). Bias in meta-analysis detected by a simple, graphical test. Bmj, 315(7109), 629-634.

Eisenberg, L. S., Kirk, K. I., Martinez, A. S., Ying, E. A., \& Miyamoto, R. T. (2004). Communication abilities of children with aided residual hearing: comparison with cochlear implant users. Archives of Otolaryngology - Head and Neck Surgery, 130(5), 563-569.

https://doi.org/10.1001/archotol.130.5.563

Fenson, L., Dale, P. S., Reznick, J. S., Bates, E., Thal, D. J., Pethick, S. J., Tomasello, M., Mervis, C. B., \& Stiles, J. (1994). Variability in Early Communicative Development. Monographs of the Society for Research in Child Development, 59(5), i-185. https://doi.org/10.2307/1166093 
medRxiv preprint doi: https://doi.org/10.1101/2021.03.02.21252684; this version posted March 27, 2021. The copyright holder for this preprint (which was not certified by peer review) is the author/funder, who has granted medRxiv a license to display the preprint in perpetuity. All rights reserved. No reuse allowed without permission.

Fisher, Z., Tipton, E., \& Zhipeng, H. (2017). robumeta: Robust variance meta-regression. $R$ package version 2.0. https://cran.r-project.org/package=robumeta

Fitzpatrick, E. M., Olds, J., Gaboury, I., McCrae, R., Schramm, D., \& Durieux-Smith, A. (2012). Comparison of outcomes in children with hearing aids and cochlear implants. Cochlear Implants International: An Interdisciplinary Journal, 13(1), 5-15. https://doi.org/10.1179/146701011X12950038111611

Foorman, B. R., Petscher, Y., \& Herrera, S. (2018). Unique and common effects of decoding and language factors in predicting reading comprehension in grades 1-10. Learning and Individual Differences, 63(February), 12-23. https://doi.org/10.1016/j.lindif.2018.02.011

*Gallego, C., Martin-Aragoneses, M. T., Lopez-Higes, R., \& Pison, G. (2016). Semantic and syntactic reading comprehension strategies used by deaf children with early and late cochlear implantation. Res Dev Disabil, 49-50, 153-170. https://doi.org/10.1016/j.ridd.2015.11.020

Ganek, H., McConkey Robbins, A., \& Niparko, J. K. (2012). Language outcomes after cochlear implantation. Otolaryngol Clin North Am, 45(1), 173-185. https://doi.org/10.1016/j.otc.2011.08.024

Geers, A., Tobey, E., Moog, J., \& Brenner, C. (2008). Long-term outcomes of cochlear implantation in the preschool years: From elementary grades to high school. International Journal of Audiology, 47(Suppl2), S21-S30. https://doi.org/10.1080/14992020802339167

Geers, Ann E., \& Hayes, H. (2011). Reading, writing, and phonological processing skills of adolescents with 10 or more years of cochlear implant experience. Ear and Hearing, 32(1 Suppl), 49s-59s. https://doi.org/10.1097/aud.0b013e3181fa41fa

Geers, Ann E. (2004). Speech, Language, and Reading Skills After Early Cochlear Implantation. Archives of Otolaryngology-Head \& Neck Surgery, 130(5), 634-638.

https://doi.org/10.1001/archotol.130.5.634

Geers, Anne E. (2003). Predictors of reading skill development in children with early cochlear 
medRxiv preprint doi: https://doi.org/10.1101/2021.03.02.21252684; this version posted March 27, 2021. The copyright holder for this preprint

(which was not certified by peer review) is the author/funder, who has granted medRxiv a license to display the preprint in perpetuity.

All rights reserved. No reuse allowed without permission.

implantation. Ear Hear, 24(1 Suppl), 59s-68s.

https://doi.org/10.1097/01.aud.0000051690.43989.5d

Gordon, K. A., \& Papsin, B. C. (2009). Benefits of Short Interimplant Delays in Children Receiving Bilateral Cochlear Implants. Otology \& Neurotology, 30(3). https://journals.Iww.com/otologyneurotology/Fulltext/2009/04000/Benefits_of_Short_Interimplant_Delays_in_Children.11.aspx

Gough, P. B., \& Tunmer, W. E. (1986). Decoding, reading, and reading disability. Remedial and Special Education, 7(1), 6-10.

Guerzoni, L., Mancini, P., Nicastri, M., Fabrizi, E., Giallini, I., \& Cuda, D. (2020). Does early cochlear implantation promote better reading comprehension skills? International Journal of Pediatric Otorhinolaryngology, 133, 109976. https://doi.org/10.1016/j.ijporl.2020.109976

Harlan, L., Margaret, D., H., G. F., M., H. H., Nicole, M., L., M. M., S., P. J., Ellen, S., Mark, T., Jennell, V., \& Majid, Z. (2007). On the Structure of Phoneme Categories in Listeners With Cochlear Implants. Journal of Speech, Language, and Hearing Research, 50(1), 2-14. https://doi.org/10.1044/1092$4388(2007 / 001)$

*Harris, M., \& Terlektsi, E. (2011). Reading and spelling abilities of deaf adolescents with cochlear implants and hearing aids. Journal of Deaf Studies and Deaf Education, 16(1), 24-34. https://doi.org/10.1093/deafed/enq031

Hayes, H., Geers, A. E., Treiman, R., \& Moog, J. S. (2009). Receptive vocabulary development in deaf children with cochlear implants: achievement in an intensive auditory-oral educational setting. Ear and Hearing, 30(1), 128-135. https://doi.org/10.1097/AUD.0b013e3181926524

Hedges, L. V., Tipton, E., \& Johnson, M. C. (2010). Robust variance estimation in meta-regression with dependent effect size estimates. Research Synthesis Methods, 1(1), 39-65. https://doi.org/10.1002/jrsm.5

Hedges, L. V. (1981). Distribution Theory for Glass's Estimator of Effect Size and Related Estimators. 
medRxiv preprint doi: https://doi.org/10.1101/2021.03.02.21252684; this version posted March 27, 2021. The copyright holder for this preprint (which was not certified by peer review) is the author/funder, who has granted medRxiv a license to display the preprint in perpetuity. All rights reserved. No reuse allowed without permission.

Journal of Educational Statistics, 6(2), 107-128. https://doi.org/10.2307/1164588

Hedges, L. V. (1989). Estimating the Normal Mean and Variance Under A Publication Selection Model BT - Contributions to Probability and Statistics: Essays in Honor of Ingram Olkin (L. J. Gleser, M. D. Perlman, S. J. Press, \& A. R. Sampson (eds.); pp. 447-458). Springer New York. https://doi.org/10.1007/978-1-4612-3678-8_31

*Henricson, C., Wass, M., Lidestam, B., Moller, C., \& Lyxell, B. (2012). Cognitive skills in children with Usher syndrome type 1 and cochlear implants. International Journal of Pediatric Otorhinolaryngology, 76(10), 1449-1457. https://doi.org/10.1016/j.ijporl.2012.06.020 Herman, R., Roy, P., \& Kyle, F. E. (2017). Reading and dyslexia in deaf children. City, University of London Institutional Repository. https://www.city.ac.uk/_data/assets/pdf_file/0011/382529/Readingand-Dyslexia-in-Deaf-Children-Herman-Roy-Kyle-2017-FINAL.pdf

Hinderink, J. B., Mens, L. H., Brokx, J. P., \& van den Broek, P. (1995). Performance of prelingually and postlingually deaf patients using single-channel or multichannel cochlear implants. The Laryngoscope, 105(6), 618-622. https://doi.org/10.1288/00005537-199506000-00011

Huang, H. S., \& Hanley, J. R. (1995). Phonological awareness and visual skills in learning to read Chinese and English. Cognition, 54(1), 73-98. https://doi.org/10.1016/0010-0277(94)00641-W

James, D., Rajput, K., Brown, T., Sirimanna, T., Brinton, J., \& Goswami, U. (2005). Phonological awareness in deaf children who use cochlear implants. Hearing Research, 48(December), 1511-1528.

*Johnson, C., \& Goswami, U. (2010). Phonological awareness, vocabulary, and reading in deaf children with cochlear implants. Journal of Speech, Language, and Hearing Research, 53(2), 237-261. https://doi.org/10.1044/1092-4388(2009/08-0139)

Kendeou, P., van den Broek, P., White, M. J., \& Lynch, J. S. (2009). Predicting reading comprehension in early elementary school: The independent contributions of oral language and decoding skills. Journal of Educational Psychology, 101(4), 765-778. https://doi.org/10.1037/a0015956 
medRxiv preprint doi: https://doi.org/10.1101/2021.03.02.21252684; this version posted March 27, 2021. The copyright holder for this preprint (which was not certified by peer review) is the author/funder, who has granted medRxiv a license to display the preprint in perpetuity. All rights reserved. No reuse allowed without permission.

Kern, M. L., \& Friedman, H. S. (2009). Early educational milestones as predictors of lifelong academic achievement, midlife adjustment, and longevity. Journal of Applied Developmental Psychology, 30(4), 419-430. https://doi.org/10.1016/j.appdev.2008.12.025

Lazard, D. S., Giraud, A.-L., Gnansia, D., Meyer, B., \& Sterkers, O. (2012). Understanding the deafened brain: implications for cochlear implant rehabilitation. European Annals of Otorhinolaryngology, Head and Neck Diseases, 129(2), 98-103. https://doi.org/10.1016/j.anorl.2011.06.001

Lederberg, A. R., Miller, E. M., Easterbrooks, S. R., \& Connor, C. M. (2014). Foundations for Literacy: An Early Literacy Intervention for Deaf and Hard-of-Hearing Children. The Journal of Deaf Studies and Deaf Education, 19(4), 438-455. https://doi.org/10.1093/deafed/enu022

Lee, Y., Yim, D., \& Sim, H. (2012). Phonological processing skills and its relevance to receptive vocabulary development in children with early cochlear implantation. International Journal of Pediatric Otorhinolaryngology, 76(12), 1755-1760. https://doi.org/10.1016/j.ijporl.2012.08.016

Lervåg, A., \& Hulme, C. (2009). Rapid automatized naming (RAN) taps a mechanism that places constraints on the development of early reading fluency. Psychological Science, 20(8), 1040-1048.

Low, D., Shipp, D., Gordon, K., Kuroiwa-Rivero, M., Cushing, S., Papsin, B., Le, T., Lin, V., \& Chen, J. (2020). Long-term Implant Usage and Quality-of-Life in Sequential Bilateral Pediatric Cochlear Implantation. Otology \& Neurotology, 41(1). https://journals.Iww.com/otologyneurotology/Fulltext/2020/01000/Long_term_Implant_Usage_and_Quality_of_Life_in.9.aspx

*Luckhurst, J. A., Lauback, C. W., \& VanSkiver, A. R. U. (2013). Differences in spoken lexical skills:

Preschool children with cochlear implants and children with typical hearing. The Volta Review, 113(1), 29-42. https://doi.org/10.17955/tvr.113.1.729

Lund, E. (2016). Vocabulary knowledge of children with cochlear implants: A meta-analysis. Journal of Deaf Studies and Deaf Education, 21(2), 107-121. https://doi.org/10.1093/deafed/env060 Mayer, C. (2007). What really matters in the early literacy development of deaf children. Journal of Deaf 
medRxiv preprint doi: https://doi.org/10.1101/2021.03.02.21252684; this version posted March 27, 2021. The copyright holder for this preprint (which was not certified by peer review) is the author/funder, who has granted medRxiv a license to display the preprint in perpetuity. All rights reserved. No reuse allowed without permission.

Studies and Deaf Education, 12(4), 411-431. https://doi.org/10.1093/deafed/enm020

Mayer, C., \& Trezek, B. J. (2018). Literacy Outcomes in Deaf Students with Cochlear Implants: Current State of the Knowledge. Journal of Deaf Studies and Deaf Education, 23(1), 1-16.

https://doi.org/http://dx.doi.org/10.1093/deafed/enx043

Mayer, C., Watson, L., Archbold, S., Ng, Z. Y., \& Mulla, I. (2016). Reading and writing skills of deaf pupils with cochlear implants. Deafness \& Education International, 18(2), 71-86. https://doi.org/10.1080/14643154.2016.1155346

Metsala, J. L., \& Walley, A. C. (1998). Spoken vocabulary growth and the segmental restructuring of lexical representations: Precursors to phonemic awareness and early reading ability.

Moher, D., Liberati, A., Tetzlaff, J., \& Altman, D. G. (2009). Preferred Reporting Items for Systematic Reviews and Meta-Analyses: The PRISMA Statement. PLoS Medicine, 6(7), e1000097. https://doi.org/10.1371/journal.pmed.1000097

Muter, V., Hulme, C., Snowling, M. J., \& Stevenson, J. (2004). Phonemes, rimes, vocabulary, and grammatical skills as foundations of early reading development: evidence from a longitudinal study. Developmental Psychology, 40(5), 665.

Nakeva von Mentzer, C., Lyxell, B., Sahlen, B., Wass, M., Lindgren, M., Ors, M., Kallioinen, P., \& Uhlen, I. (2013). Computer-assisted training of phoneme-grapheme correspondence for children who are deaf and hard of hearing: effects on phonological processing skills. International Journal of Pediatric Otorhinolaryngology, 77(12), 2049-2057. https://doi.org/10.1016/j.ijporl.2013.10.007

Nation, K., \& Snowling, M. J. (2004). Beyond phonological skills: Broader language skills contribute to the development of reading. Journal of Research in Reading, 27(4), 342-356.

https://doi.org/10.1111/j.1467-9817.2004.00238.x

National Institute of Child Health and Human Development, U. (2000). Report of the National Reading Panel: Teaching children to read: An evidence-based assessment of the scientific research literature 
medRxiv preprint doi: https://doi.org/10.1101/2021.03.02.21252684; this version posted March 27, 2021. The copyright holder for this preprint (which was not certified by peer review) is the author/funder, who has granted medRxiv a license to display the preprint in perpetuity. All rights reserved. No reuse allowed without permission.

on reading and its implications for reading instruction. NIH Publication No. 00-4769.

Neumann, M. M., Hood, M., Ford, R. M., \& Neumann, D. L. (2012). The role of environmental print in emergent literacy. Journal of Early Childhood Literacy, 12(3), 231-258.

https://doi.org/10.1177/1468798411417080

Niparko, J. K., \& Geers, A. E. (2004). Speech, Language, and Reading Skills After Early Cochlear Implantation. In JAMA: Journal of the American Medical Association (Vol. 291, Issue 19, pp. 23782380). http://10.0.3.233/jama.291.19.2378

Niparko, J. K., Tobey, E. A., Thal, D. J., Eisenberg, L. S., Wang, N.-Y., Quittner, A. L., Fink, N. E., \& Team, Cd. I. (2010). Spoken language development in children following cochlear implantation. Jama, 303(15), 1498-1506.

Niparko, J. K., Tobey, E. A., Thal, D. J., Eisenberg, L. S., Wang, N. Y., Quittner, A. L., \& Fink, N. E. (2010). Spoken language development in children following cochlear implantation. JAMA - Journal of the American Medical Association, 303(15), 1498-1506. https://doi.org/10.1001/jama.2010.451

*Nittrouer, S. (2016a). Beyond Early Intervention: Supporting Children With Cls Through Elementary School. Otology \& Neurotology : Official Publication of the American Otological Society, American Neurotology Society [and] European Academy of Otology and Neurotology, 37(2), e43-9. https://doi.org/10.1097/MAO.0000000000000906

Nittrouer, S., \& Caldwell-Tarr, A. (2016c). Language and literacy skills in children with cochlear implants: Past and present findings. In Pediatric cochlear implantation (pp. 177-197). Springer.

*Nittrouer, S., Caldwell-Tarr, A., Sansom, E., Twersky, J., \& Lowenstein, J. H. (2014). Nonword repetition in children with cochlear implants: A potential clinical marker of poor language acquisition. American Journal of Speech-Language Pathology, 23(4), 679-695. https://doi.org/10.1044/2014_AJSLP-14-0040

*Nittrouer, S., Caldwell, A., \& Holloman, C. (2012a). Measuring what matters: effectively predicting 
medRxiv preprint doi: https://doi.org/10.1101/2021.03.02.21252684; this version posted March 27, 2021. The copyright holder for this preprint (which was not certified by peer review) is the author/funder, who has granted medRxiv a license to display the preprint in perpetuity. All rights reserved. No reuse allowed without permission.

language and literacy in children with cochlear implants. International Journal of Pediatric Otorhinolaryngology, 76(8), 1148-1158. https://doi.org/10.1016/j.ijporl.2012.04.024

*Nittrouer, S., Caldwell, A., Lowenstein, J. H., Tarr, E., \& Holloman, C. (2012b). Emergent literacy in kindergartners with cochlear implants. Ear and Hearing, 33(6), 683.

https://doi.org/10.1097/AUD.0b013e318258c98e

*Nittrouer, S., Lowenstein, J. H., \& Holloman, C. (2016b). Early predictors of phonological and morphosyntactic skills in second graders with cochlear implants. Research in Developmental Disabilities, 55, 143-160. https://doi.org/10.1016/j.ridd.2016.03.020

*Nittrouer, S., Muir, M., Tietgens, K., Moberly, A. C., \& Lowenstein, J. H. (2018). Development of phonological, lexical, and syntactic abilities in children with cochlear implants across the elementary grades. Journal of Speech, Language, and Hearing Research, 61(10), 2561-2577. https://doi.org/10.1044/2018_JSLHR-H-18-0047

Norton, E. S., \& Wolf, M. (2012). Rapid automatized naming (RAN) and reading fluency: Implications for understanding and treatment of reading disabilities. Annual Review of Psychology, 63, 427-452.

Nott, P., Cowan, R., Brown, P. M., \& Wigglesworth, G. (2009). Early Language Development in Children with Profound Hearing Loss Fitted with a Device at a Young Age: Part I-The Time Period Taken to Acquire First Words and First Word Combinations. Ear and Hearing, 30(5). https://journals.Iww.com/earhearing/Fulltext/2009/10000/Early_Language_Development_in_Children_with.5.aspx

Paul, P. V., \& Alqraini, F. (2019). Conclusion: Perspectives on language, literacy, and deafness. Education Sciences, 9(4), 1-14. https://doi.org/10.3390/educsci9040286

Paul, P. V. (1998). Literacy and deafness: The development of reading, writing, and literate thought. Allyn and Bacon Boston.

Petrill, S. A., Deater-Deckard, K., Thompson, L. A., DeThorne, L. S., \& Schatschneider, C. (2006). Reading 
medRxiv preprint doi: https://doi.org/10.1101/2021.03.02.21252684; this version posted March 27, 2021. The copyright holder for this preprint (which was not certified by peer review) is the author/funder, who has granted medRxiv a license to display the preprint in perpetuity. All rights reserved. No reuse allowed without permission.

skills in early readers: Genetic and shared environmental influences. Journal of Learning Disabilities, 39(1), 48-55. https://doi.org/10.1177/00222194060390010501

Pikulski, J. J., \& Chard, D. J. (2005). Fluency: Bridge between decoding and reading comprehension. The Reading Teacher, 58(6), 510-519.

Pustejovsky, J. (2017). clubSandwich: Cluster-robust (sandwich) variance estimators with small-sample corrections. R Package Version 0.2, 3.

Rastegarianzadeh, N., Shahbodaghi, M., \& Faghihzadeh, S. (2014). Study of Phonological Awareness of Preschool and School Aged Children with Cochlear Implant and Normal Hearing. Korean Journal of Audiology, 18(2), 50-53. http://10.0.30.194/kja.2014.18.2.50

Rezaei, M., Rashedi, V., \& Morasae, E. K. (2016). Reading skills in Persian deaf children with cochlear implants and hearing aids. International Journal of Pediatric Otorhinolaryngology, 89, 1-5. https://doi.org/10.1016/j.ijporl.2016.07.010

Rosenthal, R. (1979). The file drawer problem and tolerance for null results. Psychological Bulletin, 86(3), 638-641. https://doi.org/10.1037/0033-2909.86.3.638

Ruff, S., Bocklet, T., Nöth, E., Müller, J., Hoster, E., \& Schuster, M. (2017). Speech Production Quality of Cochlear Implant Users with Respect to Duration and Onset of Hearing Loss. ORL, 79(5), 282-294. https://doi.org/10.1159/000479819

Sarant, J., Harris, D., Bennet, L., \& Bant, S. (2014). Bilateral versus unilateral cochlear implants in children: a study of spoken language outcomes. Ear and Hearing, 35(4), 396-409. https://doi.org/10.1097/AUD.0000000000000022

Sarant, J. Z., Harris, D. C., \& Bennet, L. A. (2015). Academic outcomes for school-aged children with severe-profound hearing loss and early unilateral and bilateral cochlear implants. Journal of Speech, Language, and Hearing Research, 58(3), 1017-1032. https://doi.org/10.1044/2015_JSLHR$\mathrm{H}-14-0075$ 
medRxiv preprint doi: https://doi.org/10.1101/2021.03.02.21252684; this version posted March 27, 2021. The copyright holder for this preprint (which was not certified by peer review) is the author/funder, who has granted medRxiv a license to display the preprint in perpetuity. All rights reserved. No reuse allowed without permission.

*Schorr, E. A., Roth, F. P., \& Fox, N. A. (2008). A Comparison of the Speech and Language Skills of Children With Cochlear Implants and Children With Normal Hearing. Communication Disorders Quarterly, 29(4), 195-210. https://doi.org/10.1177/1525740108321217

Seldran, F., Gallego, S., Micheyl, C., Veuillet, E., Truy, E., \& Thai-Van, H. (2011). Relationship between age of hearing-loss onset, hearing-loss duration, and speech recognition in individuals with severe-toprofound high-frequency hearing loss. Journal of the Association for Research in Otolaryngology: JARO, 12(4), 519-534. https://doi.org/10.1007/s10162-011-0261-8

Shanahan, T., \& Lonigan, C. J. (2010). The National Early Literacy Panel: A Summary of the Process and the Report. Educational Researcher, 39(4), 279-285. https://doi.org/10.3102/0013189X10369172

Sharma, A., Dorman, M. F., \& Spahr, A. J. (2002). A sensitive period for the development of the central auditory system in children with cochlear implants: implications for age of implantation. Ear and Hearing, 23(6), 532-539.

Sharma, A., Nash, A. A., \& Dorman, M. (2009). Cortical development, plasticity and re-organization in children with cochlear implants. Journal of Communication Disorders, 42(4), 272-279.

Silverman, R. D., Speece, D. L., Harring, J. R., \& Ritchey, K. D. (2013). Fluency Has a Role in the Simple View of Reading. Scientific Studies of Reading, 17(2), 108-133.

https://doi.org/10.1080/10888438.2011.618153

Snowling, M. J., \& Melby-Lervåg, M. (2016). Oral language deficits in familial dyslexia: A meta-analysis and review. Psychological Bulletin, 142(5), 498.

Sohail, I., \& Nabeel, T. (2019). Comparison of Reading Development in Children with Hearing Impairment Using Hearing Aids and Cochlear Implant. Journal of Inclusive Education, 3(1).

*Soleymani, Z., Mahmoodabadi, N., \& Nouri, M. M. (2016). Language skills and phonological awareness in children with cochlear implants and normal hearing. International Journal of Pediatric Otorhinolaryngology, 83, 16-21. https://doi.org/10.1016/j.ijporl.2016.01.013 
medRxiv preprint doi: https://doi.org/10.1101/2021.03.02.21252684; this version posted March 27, 2021. The copyright holder for this preprint (which was not certified by peer review) is the author/funder, who has granted medRxiv a license to display the preprint in perpetuity. All rights reserved. No reuse allowed without permission.

Sparreboom, M., Langereis, M. C., Snik, A. F. M., \& Mylanus, E. A. M. (2015). Long-term outcomes on spatial hearing, speech recognition and receptive vocabulary after sequential bilateral cochlear implantation in children. Research in Developmental Disabilities, 36, 328-337. https://doi.org/10.1016/j.ridd.2014.10.030

Spencer, L. J., Barker, B. A., \& Tomblin, J. B. (2003). Exploring the language and literacy outcomes of pediatric cochlear implant users. Ear and Hearing, 24(3), 236-247.

https://doi.org/10.1097/01.AUD.0000069231.72244.94

Spencer, L. J., \& Tomblin, J. B. (2009). Evaluating phonological processing skills in children with prelingual deafness who use cochlear implants. Journal of Deaf Studies and Deaf Education, 14(1), 1-21.

Stanovich, K. E. (1986). Matthew Effects in Reading: Some Consequences of Individual Differences in the Acquisition of Literacy. Reading Research Quarterly, 21(4), 360-407. https://doi.org/10.1598/rrq.21.4.1

Suggate, S. P. (2016). A Meta-Analysis of the Long-Term Effects of Phonemic Awareness, Phonics, Fluency, and Reading Comprehension Interventions. Journal of Learning Disabilities, 49(1), 77-96. https://doi.org/10.1177/0022219414528540

Therrien, W. J. (2004). Fluency and comprehension gains as a result of repeated reading: A metaanalysis. Remedial and Special Education, 25(4), 252-261.

Tipton, E., \& Pustejovsky, J. E. (2015). Small-sample adjustments for tests of moderators and model fit using robust variance estimation in meta-regression. Journal of Educational and Behavioral Statistics, 40(6), 604-634.

Traxler, M. J. (2017). Using Multilevel Models to Evaluate Individual Differences in Deaf Readers. Research in Deaf Education: Contexts, Challenges, and Considerations, 309.

Trezek, B, Wang, Y., \& Paul, P. (2010). Reading and deafness. Theory, Research and Practice.

Trezek, Beverly, \& Mayer, C. (2019). Reading and deafness: State of the evidence and implications for 
medRxiv preprint doi: https://doi.org/10.1101/2021.03.02.21252684; this version posted March 27, 2021. The copyright holder for this preprint (which was not certified by peer review) is the author/funder, who has granted medRxiv a license to display the preprint in perpetuity. All rights reserved. No reuse allowed without permission.

research and practice. Education Sciences, 9(3). https://doi.org/10.3390/educsci9030216

*Tse, W. T., \& So, L. K. H. (2012). Phonological awareness of Cantonese-speaking pre-school children with cochlear implants. International Journal of Speech-Language Pathology, 14(1), 73-83. https://doi.org/10.3109/17549507.2011.604428

*van der Kant, A., Vermeulen, A., Raeve, L. De, \& Schreuder, R. (2010). Reading comprehension of flemish deaf children in belgium: Sources of variability in reading comprehension after cochlear implantation. Deafness and Education International, 12(2), 77-98.

https://doi.org/10.1179/146431510X12626982043769

Vatalaro, A., Culp, A. M., Hahs-Vaughn, D. L., \& Barnes, A. C. (2018). A Quasi-Experiment Examining Expressive and Receptive Vocabulary Knowledge of Preschool Head Start Children Using Mobile Media Apps. Early Childhood Education Journal, 46(4), 451-466. https://doi.org/10.1007/s10643017-0877-3

*Vermeulen, A. M., van Bon, W., Schreuder, R., Knoors, H., \& Snik, A. (2007). Reading comprehension of deaf children with cochlear implants. Journal of Deaf Studies and Deaf Education, 12(3), 283-302. https://doi.org/10.1093/deafed/enm017

Viechtbauer, W., \& Cheung, M. W.-L. (2010). Outlier and influence diagnostics for meta-analysis. Research Synthesis Methods, 1(2), 112-125. https://doi.org/10.1002/jrsm.11

Wang, Y., Shafto, C. L., \& Houston, D. M. (2018). Attention to speech and spoken language development in deaf children with cochlear implants: a 10-year longitudinal study. DEVELOPMENTAL SCIENCE, 21(6). https://doi.org/10.1111/desc.12677

*Wass, M., Ibertsson, T., Lyxell, B., Sahlen, B., Hallgren, M., LARSBY, B., \& Maki-torkko, E. (2008). Cognitive and linguistic skills in Swedish children with cochlear implants - measures of accuracy and latency as indicators of development. Scandinavian Journal of Psychology, 49(6), 559-576. https://doi.org/10.1111/j.1467-9450.2008.00680.x 
medRxiv preprint doi: https://doi.org/10.1101/2021.03.02.21252684; this version posted March 27, 2021. The copyright holder for this preprint (which was not certified by peer review) is the author/funder, who has granted medRxiv a license to display the preprint in perpetuity. All rights reserved. No reuse allowed without permission.

Watson, L. (2002). The literacy development of children with cochlear implants at age seven. Deafness \& Education International, 4(2), 84-98.

Wechsler-Kashi, D., Schwartz, R. G., \& Cleary, M. (2014). Picture naming and verbal fluency in children with cochlear implants. Journal of Speech, Language, and Hearing Research, 57(5), 1870-1882. https://doi.org/10.1044/2014_JSLHR-L-13-0321

Wei, C. G., Cao, K., \& Zeng, F. G. (2004). Mandarin tone recognition in cochlear-implant subjects. Hearing Research, 197(1-2), 87-95. https://doi.org/10.1016/j.heares.2004.06.002

*Weisi, F., Rezaei, M., Rashedi, V., Heidari, A., Valadbeigi, A., \& Ebrahimi-Pour, M. (2013). Comparison of reading skills between children with cochlear implants and children with typical hearing in Iran. International Journal of Pediatric Otorhinolaryngology, 77(8), 1317-1321.

https://doi.org/10.1016/j.ijporl.2013.05.023

Werfel, K. L., Douglas, M., \& Ackal, L. (2016). Small-group phonological awareness training for prekindergarten children with hearing loss who wear cochlear implants and/or hearing aids. Deafness \& Education International, 18(3), 134-140. https://doi.org/10.1080/14643154.2016.1190117

Wilson, D. B. (2014). Practical Meta-Analysis Effect Size Calculator. Campbell Collaboration. http://www.campbellcollaboration.org/resources/effect_size_input.php

Worsfold, S., Mahon, M., Pimperton, H., Stevenson, J., \& Kennedy, C. (2018). Predicting reading ability in teenagers who are deaf or hard of hearing: A longitudinal analysis of language and reading. Research in Developmental Disabilities, 77, 49-59.

Yoshinaga-Itano, C., Sedey, A. L., Wiggin, M., \& Mason, C. A. (2018). Language outcomes improved through early hearing detection and earlier cochlear implantation. Otology and Neurotology, 39(10), 1256-1263. https://doi.org/10.1097/MAO.0000000000001976 
medRxiv preprint doi: https://doi.org/10.1101/2021.03.02.21252684; this version posted March 27, 2021. The copyright holder for this preprint (which was not certified by peer review) is the author/funder, who has granted medRxiv a license to display the preprint in perpetuity. All rights reserved. No reuse allowed without permission.

44

\section{Tables}

Table 1. RVE models of each construct for $\mathrm{Cl}$ versus TH

\begin{tabular}{lccccccc}
\hline & $\begin{array}{c}\text { Hedges' } \\
\mathrm{g}\end{array}$ & $\begin{array}{c}95 \% \\
\text { Confidence } \\
\text { Interval }\end{array}$ & $\begin{array}{c}p \\
\text { value }\end{array}$ & $\begin{array}{c}\# \\
\text { Samples }\end{array}$ & $\begin{array}{c}\# \\
\text { Effects }\end{array}$ & $\begin{array}{c}1^{2} \\
(\%)\end{array}$ & $\tau^{2}$ \\
\hline RVE models for each construct & -1.62 & {$[-2.40-.84]$} & $<.001^{*}$ & 14 & 37 & 88 & 1.00 \\
\hline PA & -1.50 & {$[-1.87-1.14]$} & $<.001^{*}$ & 29 & 38 & 84 & 0.57 \\
Vocabulary & -.40 & {$[-1.12 .32]$} & .199 & 5 & 7 & 73 & .26 \\
Receptive Vocabulary & -1.57 & {$[-1.92-1.21]$} & $<.001^{*}$ & 28 & 31 & 83 & .53 \\
Expressive Vocabulary & -1.24 & {$[-1.82-.66]$} & $<.001^{*}$ & 18 & 31 & 91 & 1.26 \\
Decoding & -.67 & {$[-1.35 .17]$} & 0.054 & 5 & 8 & 66 & .20 \\
Fluency & -1.39 & {$[-2.10-.68]$} & $<.001^{*}$ & 16 & 20 & 88 & .85 \\
Reading Comprehension & & & & & & &
\end{tabular}


medRxiv preprint doi: https://doi.org/10.1101/2021.03.02.21252684; this version posted March 27, 2021. The copyright holder for this preprint (which was not certified by peer review) is the author/funder, who has granted medRxiv a license to display the preprint in perpetuity. All rights reserved. No reuse allowed without permission.

45

Table 2. Moderator Analyses for $\mathrm{Cl}$ versus TH

\begin{tabular}{lcccccc}
\hline & Statistics & $\begin{array}{c}p \\
\text { value }\end{array}$ & $\begin{array}{c}\# \\
\text { Samples }\end{array}$ & \# Effects & $\begin{array}{c}\mathrm{I}^{2} \\
(\%)\end{array}$ & $\tau^{2}$ \\
\hline Categorical Moderators & F value & & & & & \\
\hline Construct (5 levels) & 1.76 & .192 & 43 & 134 & 88 & .75 \\
Vocabulary (2 levels) & 15.4 & $.015^{*}$ & 29 & 38 & 83 & .52 \\
\hline Continues Moderators & B Estimates & & & & & \\
\hline Cl group's Age at testing & -.001 & .832 & 32 & 119 & 86 & .65 \\
Cl group's Age at onset of deafness & -.046 & .514 & 21 & 71 & 89 & .95 \\
Cl group's Age at implantation & .005 & .449 & 38 & 115 & 87 & .65 \\
Cl group's Duration of implant use & -.004 & .270 & 28 & 98 & 85 & .57 \\
Cl group's Percentage of unilateral Cl & -.018 & $.008^{*}$ & 21 & 69 & 78 & .37 \\
\hline
\end{tabular}

$* p<.05$ 
medRxiv preprint doi: https://doi.org/10.1101/2021.03.02.21252684; this version posted March 27, 2021. The copyright holder for this preprint (which was not certified by peer review) is the author/funder, who has granted medRxiv a license to display the preprint in perpetuity. All rights reserved. No reuse allowed without permission.

46

Table 3. RVE models of each construct for $\mathrm{Cl}$ versus $\mathrm{HA}$

\begin{tabular}{lccccccc}
\hline & $\begin{array}{c}\text { Hedges' } \\
\mathrm{g}\end{array}$ & $\begin{array}{c}95 \% \\
\text { Confidence } \\
\text { Interval }\end{array}$ & $\begin{array}{c}p \\
\text { value }\end{array}$ & $\begin{array}{c}\# \\
\text { Samples }\end{array}$ & $\begin{array}{c}\# \\
\text { Effects }\end{array}$ & $\begin{array}{c}\mathrm{I}^{2} \\
(\%)\end{array}$ & $\tau^{2}$ \\
\hline RVE models for each construct & & & & & & & \\
\hline PA & -.30 & {$[-.55-.06]$} & $.028^{*}$ & 6 & 13 & 0 & .00 \\
Vocabulary & -.08 & {$[-.50 .34]$} & .692 & 13 & 15 & 79 & .43 \\
Decoding & -.24 & {$[-.61 .13]$} & .179 & 11 & 18 & 65 & .22 \\
Fluency & \\
Reading Comprehension & -.24 & $\mathrm{~N} / \mathrm{A}$ & $\mathrm{N} / \mathrm{A}$ & $\mathrm{N} / \mathrm{A}$ & $\mathrm{N} / \mathrm{A}$ & $\mathrm{N} / \mathrm{A}$ & $\mathrm{N} / \mathrm{A}$ \\
\hline R & .08 & {$[-.22 .38]$} & .568 & 11 & 11 & 53 & .10 \\
\hline
\end{tabular}

$* p<.05,{ }^{+}$degree of freedom $<4$ and RVE result was not reliable. 
medRxiv preprint doi: https://doi.org/10.1101/2021.03.02.21252684; this version posted March 27, 2021. The copyright holder for this preprint (which was not certified by peer review) is the author/funder, who has granted medRxiv a license to display the preprint in perpetuity.

All rights reserved. No reuse allowed without permission.

Figure Legends

Figure 1. Preferred Reporting of Systematic Reviews and Meta-Analyses. $k$ is the number of articles. 


\section{Records identified through database} searching $(k=5,642)$
Records excluded if they are duplicates or irrelevant $(\mathrm{k}=4,676)$

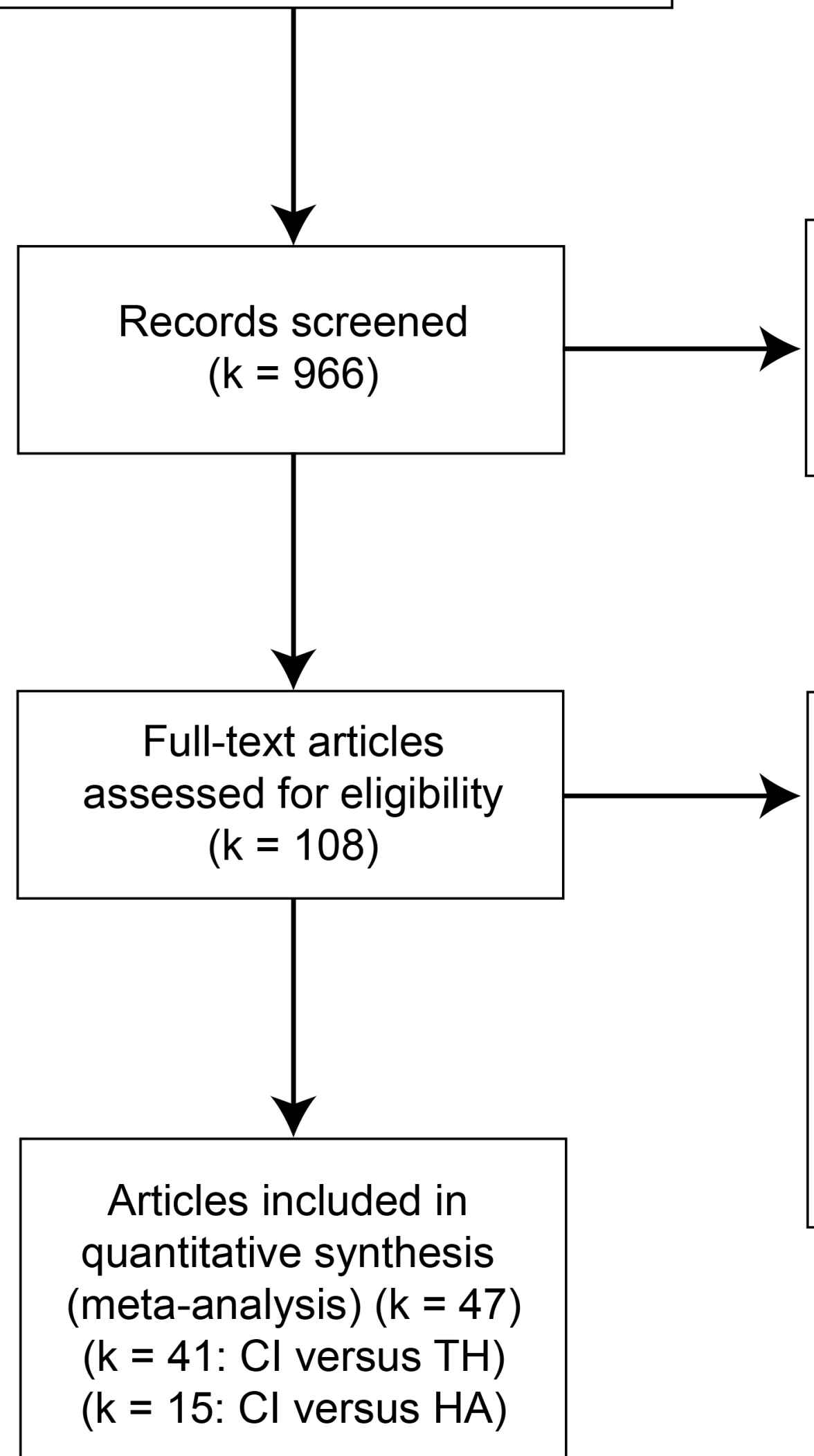

Records excluded if they are irrelevant

$$
(k=858)
$$

Full-text articles excluded $(k=61)$

- Comparison groups were not age-matched $(k=7)$

- No comparison group $(k=8)$

- Age range was outside of $3-18$ years old $(k=6)$

- Participants with other conditions $(k=5)$

- Did not collect reading skills fitting into five constructs $(k=6)$

- Case studies $(k=3)$

- Authors indicated data unavailable $(k=2)$

- No response from authors $(k=8)$

- Non-parametric effects $(k=2)$

- No $\mathrm{Cl}$ group/Cl and $\mathrm{HA}$ group were combined $(\mathrm{k}=5)$

- Data from the same group of researchers whose articles have already been included $(k=9)$ 


\section{Appendix A. Supplementary Tables}

Supplementary Table A.1 Study Characteristics

\begin{tabular}{|c|c|c|c|c|}
\hline \multirow{2}{*}{$\begin{array}{l}\text { Group Comparison } \\
\text { Study Characteristic }\end{array}$} & \multicolumn{2}{|c|}{ Cl vs. TH } & \multicolumn{2}{|c|}{$\mathrm{Cl}$ vs. HA } \\
\hline & $\begin{array}{c}\text { \# of } \\
\text { articles }\end{array}$ & $\begin{array}{c}\text { Percentage } \\
(\%)\end{array}$ & $\begin{array}{c}\text { \# of } \\
\text { articles }\end{array}$ & $\begin{array}{c}\text { Percentage } \\
\text { (\%) }\end{array}$ \\
\hline \multicolumn{5}{|l|}{ Publication Year } \\
\hline $2002-2005$ & 2 & 5 & 1 & 7 \\
\hline 2006-2010 & 7 & 17 & 3 & 20 \\
\hline 2011-2015 & 20 & 49 & 9 & 60 \\
\hline 2016-2019 & 12 & 29 & 2 & 13 \\
\hline \multicolumn{5}{|l|}{ Language } \\
\hline English & 20 & 49 & 9 & 60 \\
\hline Swedish & 5 & 12 & 3 & 20 \\
\hline Farsi & 4 & 11 & 1 & 7 \\
\hline Flemish & N/A & N/A & 1 & 7 \\
\hline Korean & 2 & 5 & N/A & N/A \\
\hline Spanish & 2 & 5 & N/A & N/A \\
\hline Turkish & 2 & 5 & N/A & N/A \\
\hline Mandarin & 2 & 5 & 1 & 7 \\
\hline Dutch & 1 & 2 & N/A & N/A \\
\hline Hindi & 1 & 2 & N/A & N/A \\
\hline German & 1 & 2 & N/A & N/A \\
\hline Italian & 1 & 2 & N/A & N/A \\
\hline \multicolumn{5}{|l|}{ Publication } \\
\hline Journal & 38 & 93 & 14 & 93 \\
\hline \multirow[t]{2}{*}{ Thesis } & 3 & 7 & 1 & 7 \\
\hline & $\begin{array}{c}\text { \# of } \\
\text { effects }\end{array}$ & $\begin{array}{c}\text { Percentage } \\
(\%)\end{array}$ & $\begin{array}{c}\text { \# of } \\
\text { effects }\end{array}$ & $\begin{array}{c}\text { Percentage } \\
\text { (\%) }\end{array}$ \\
\hline \multicolumn{5}{|c|}{ Sample Size of Children with Cls } \\
\hline$<=10$ & 20 & 15 & 11 & 19 \\
\hline $11-30$ & 91 & 68 & 43 & 73 \\
\hline $31-50$ & 14 & 10 & 5 & 8 \\
\hline $51-70$ & 8 & 6 & & \\
\hline$>=71$ & 1 & 1 & & \\
\hline
\end{tabular}


Supplementary Table A.2 All articles included in the current study

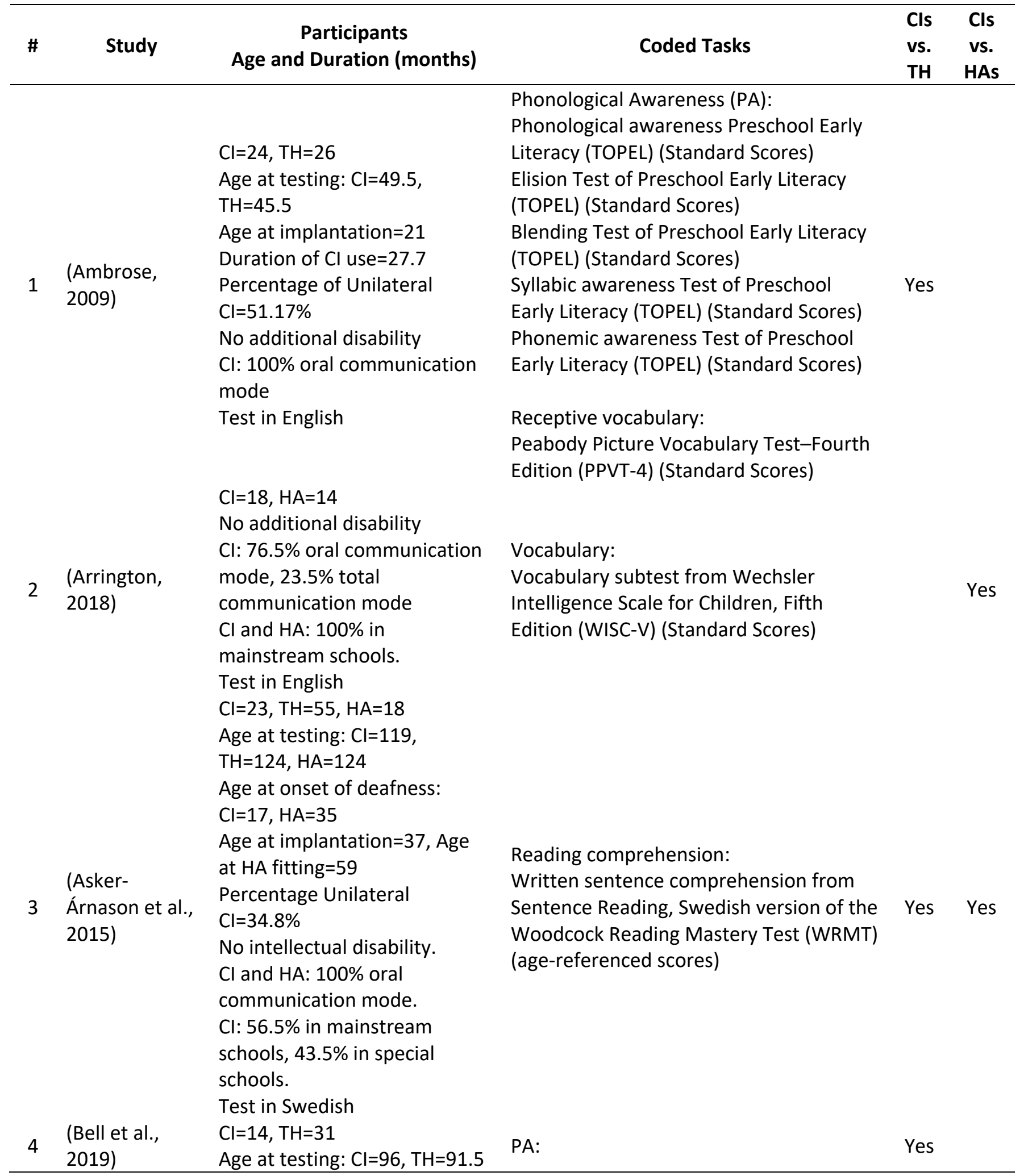




\begin{tabular}{|c|c|c|c|c|}
\hline & & $\begin{array}{l}\text { Age at implantation }=20.9 \\
\text { Duration of } \mathrm{Cl} \text { use }=74.8 \\
\text { Percentage Unilateral } \\
\mathrm{Cl}=14.3 \% \\
\text { No diagnosed developmental } \\
\text { disorders or intellectual } \\
\text { disabilities. } \\
\mathrm{Cl}: 100 \% \text { oral communication } \\
\text { mode. } \\
\mathrm{Cl}: 100 \% \text { in mainstream } \\
\text { schools. } \\
\text { Test in English }\end{array}$ & $\begin{array}{l}\text { Comprehensive Test of Phonological } \\
\text { Processing-Second Edition (CTOPP-2) } \\
\text { (Standard Scores) } \\
\text { Receptive vocabulary: } \\
\text { PPVT-4 (Standard Scores) } \\
\text { Decoding: } \\
\text { Nonword reading Castles and Coltheart } \\
\text { Test } 2 \text { (Standardized Z scores) } \\
\text { Regular word reading Castles and } \\
\text { Coltheart Test } 2 \text { (Standardized Z scores) } \\
\text { Irregular word reading Castles and } \\
\text { Coltheart Test } 2 \text { (Standardized Z scores) } \\
\text { Fluency: } \\
\text { Reading rate (paragraph) Primary } \\
\text { Passage subtest of the York Assessment } \\
\text { of Reading for Comprehension- } \\
\text { Australian Edition (YARC) (Standard } \\
\text { Scores) } \\
\text { Rapid Automized Naming (Standard } \\
\text { Scores) } \\
\text { Reading comprehension: } \\
\text { Primary Passage subtest of the YARC } \\
\text { (Standard Scores) }\end{array}$ & \\
\hline 5 & $\begin{array}{l}\text { (Bouton et al., } \\
\text { 2011) }\end{array}$ & $\begin{array}{l}\mathrm{Cl}=9, \mathrm{TH}=9 \\
\text { Age at testing: } \mathrm{Cl}=109, \\
\mathrm{TH}=109 \\
\text { Duration of } \mathrm{Cl} \text { use=32 } \\
\text { Duration of } \mathrm{Cl}=77 \\
\text { No intellectual disability. } \\
\mathrm{Cl}: 66.7 \% \text { oral communication } \\
\text { mode, } 33.3 \% \text { oral and sign } \\
\text { mixed communication mode. } \\
\mathrm{Cl}: 55.5 \% \text { in mainstream } \\
\text { schools. } 44.5 \% \text { in special } \\
\text { schools. } \\
\text { Test in French } \\
\mathrm{Cl}=17, \mathrm{TH}=17 \\
\text { Age at testing: } \mathrm{Cl}=53.8, \mathrm{TH}=54 \\
\text { Age at onset of deafness: } \mathrm{Cl} \\
=6.6 \\
\text { Age at implantation=15.9 } \\
\text { Duration of } \mathrm{Cl} \text { use }=37.11 \\
\text { Percentage Unilateral } \mathrm{Cl}=47 \% \\
\text { No additional deficits. }\end{array}$ & $\begin{array}{l}\text { PA: } \\
\text { Phonemic similarity judgement task } \\
\text { (Percentage of correct responses) } \\
\text { Decoding: } \\
\text { Pseudowords reading (T-stats) } \\
\text { Irregular words reading (T-stats) } \\
\text { Fluency: } \\
\text { Fluency Alouette Test (T-stats) }\end{array}$ & Yes \\
\hline
\end{tabular}




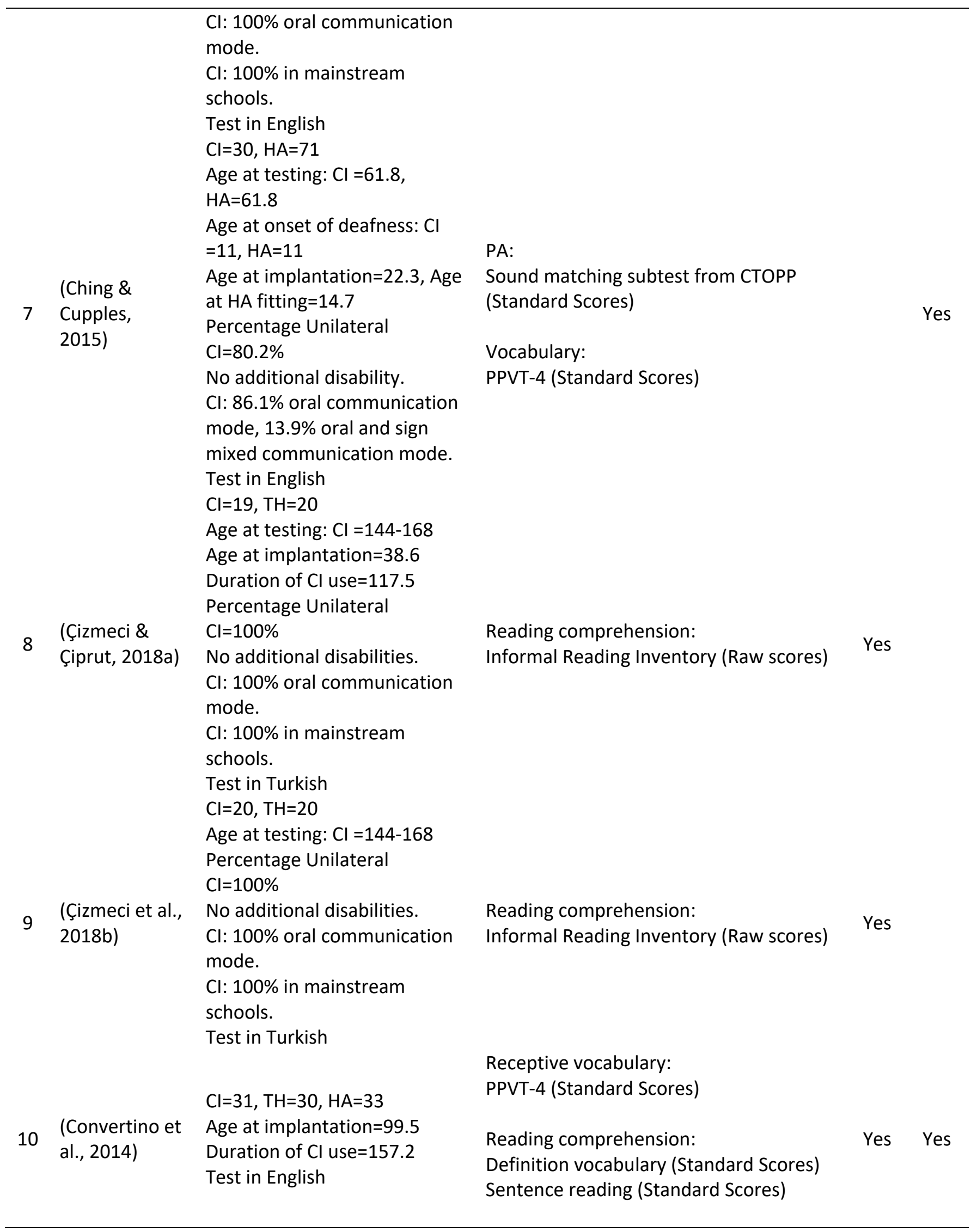




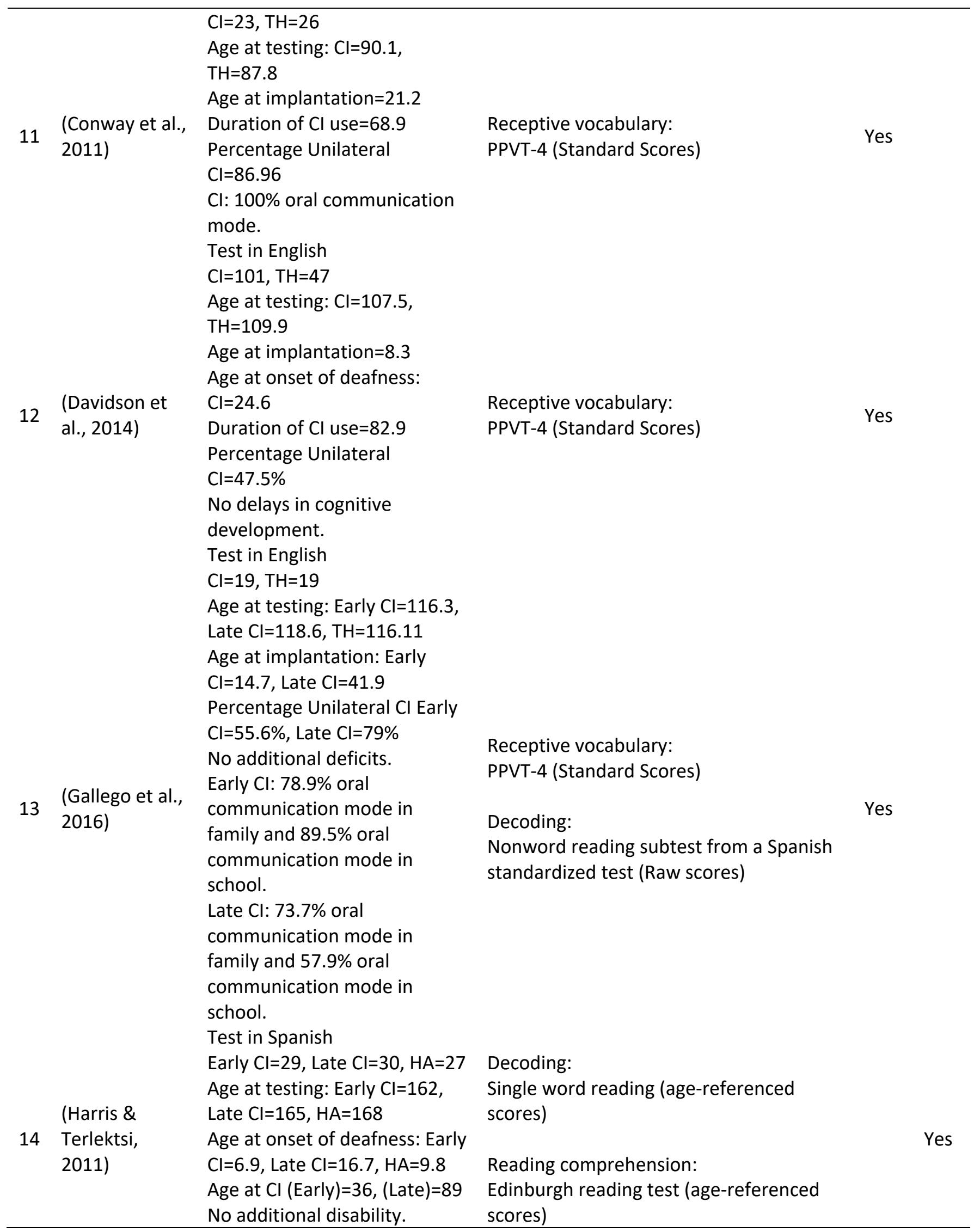




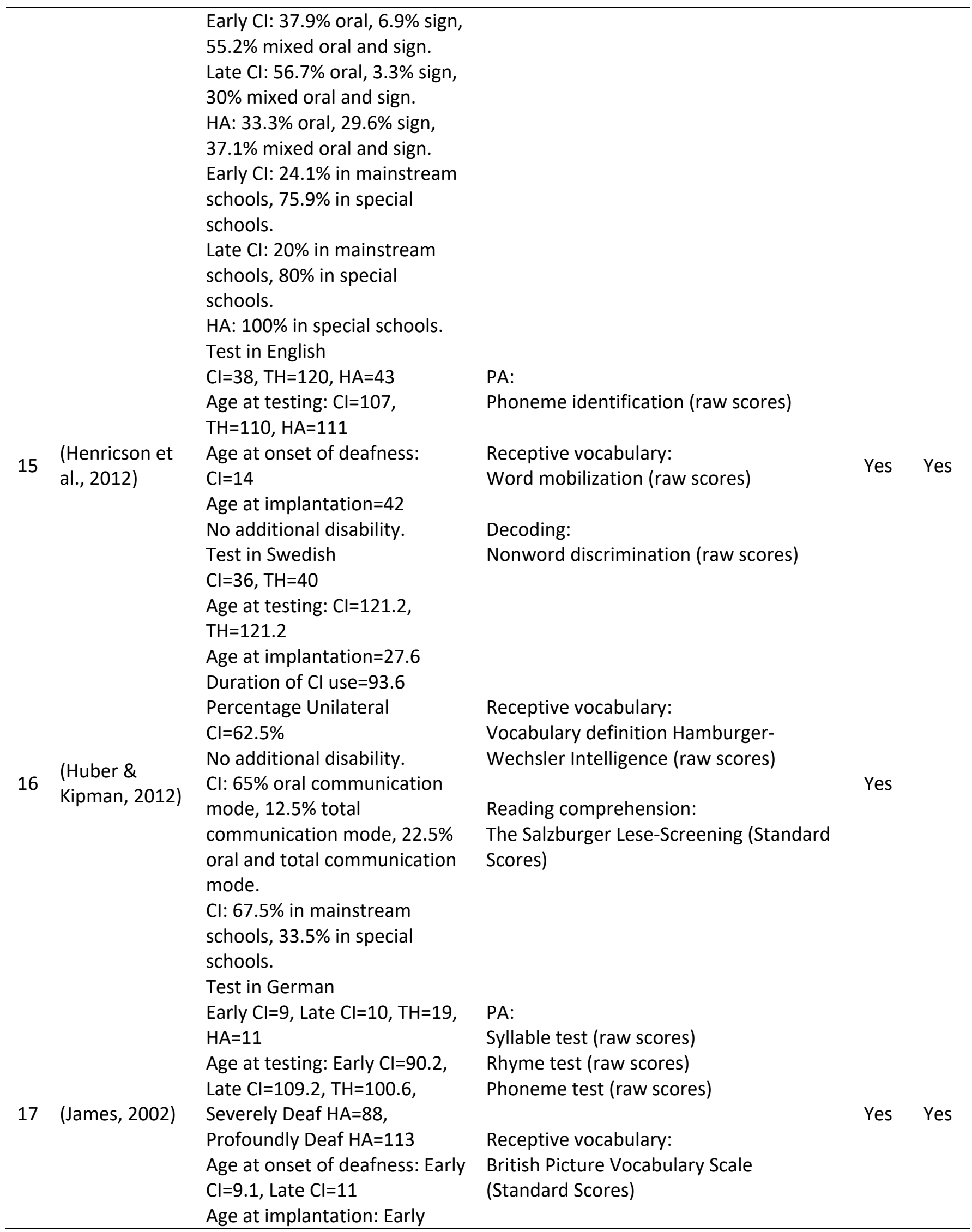




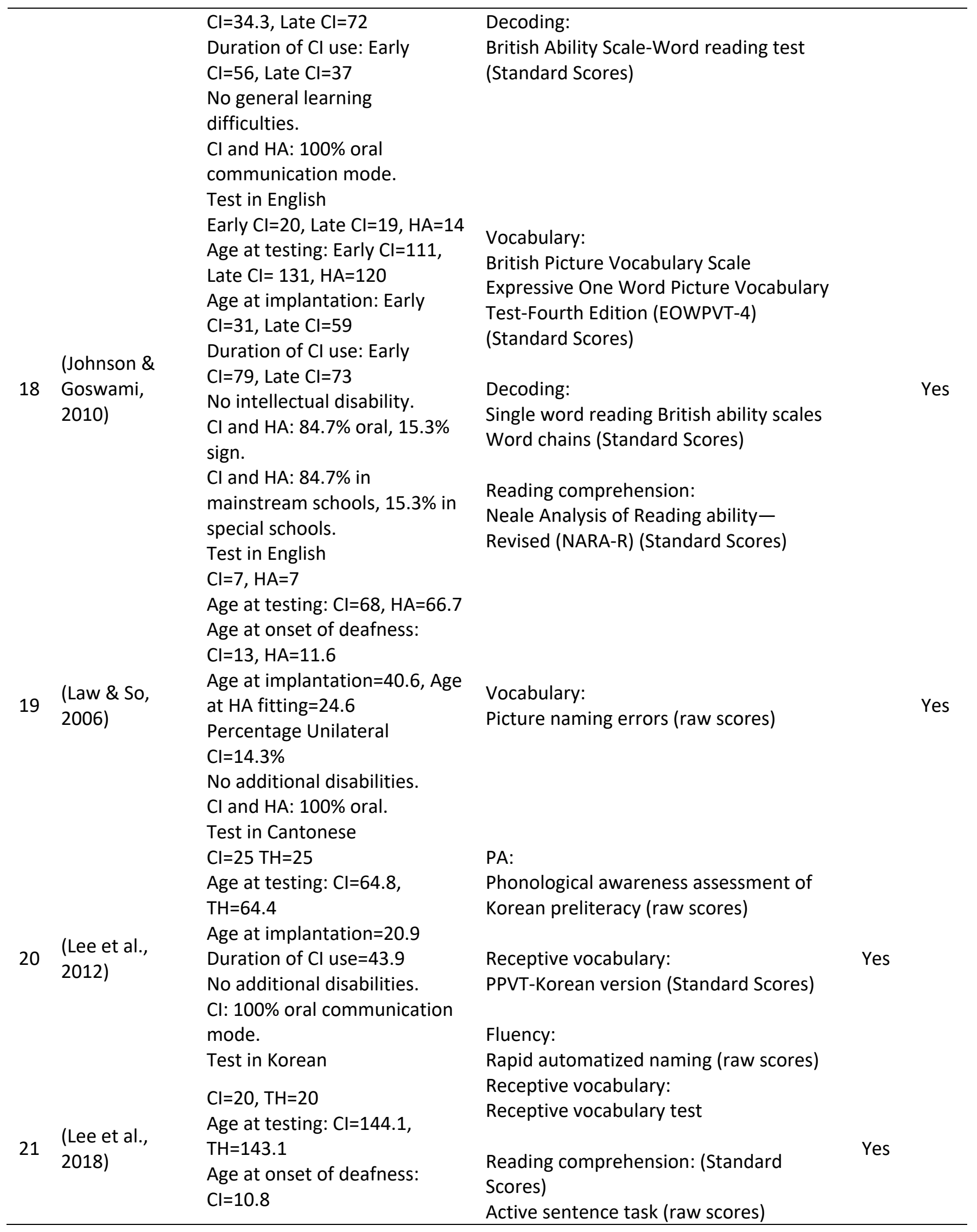




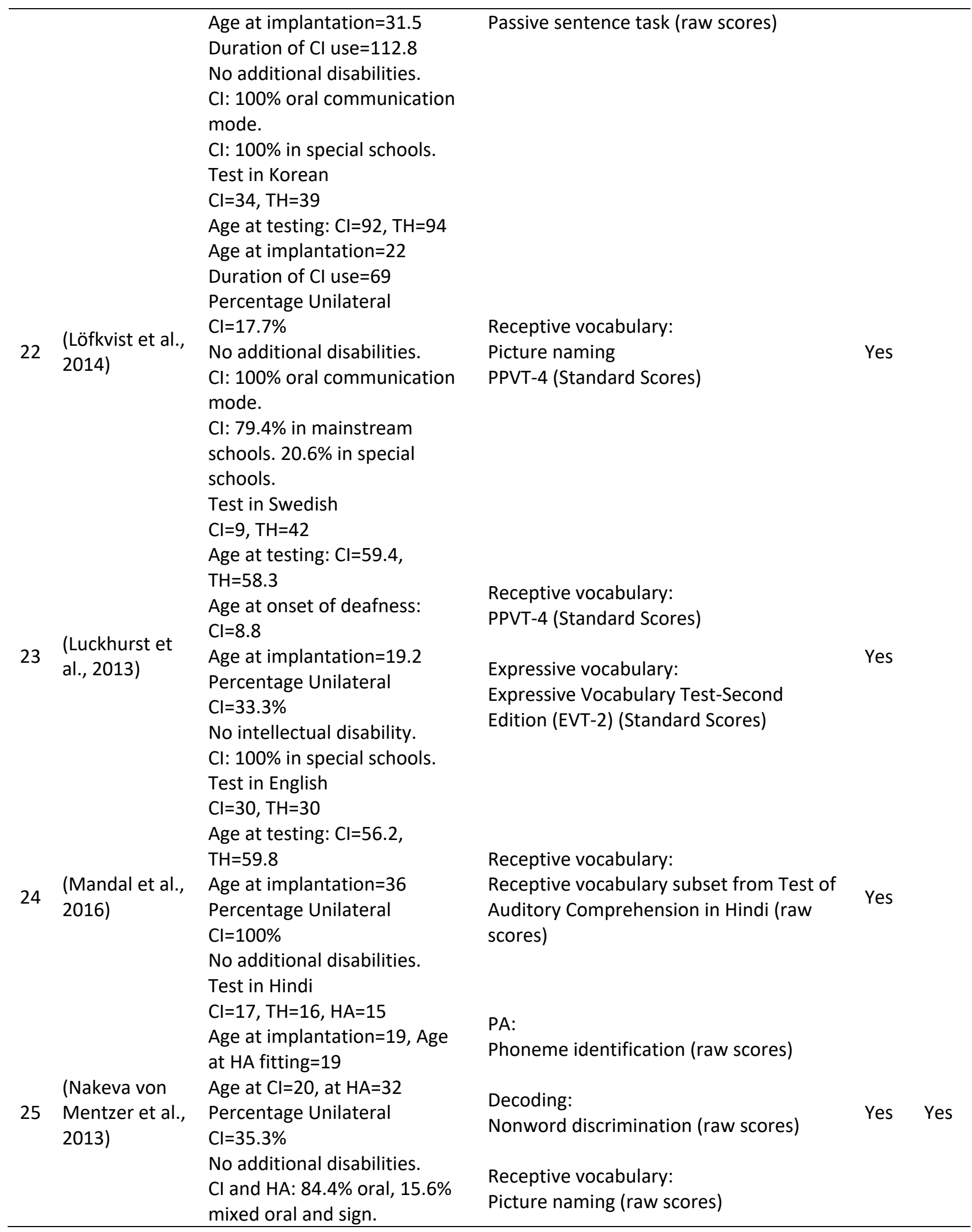




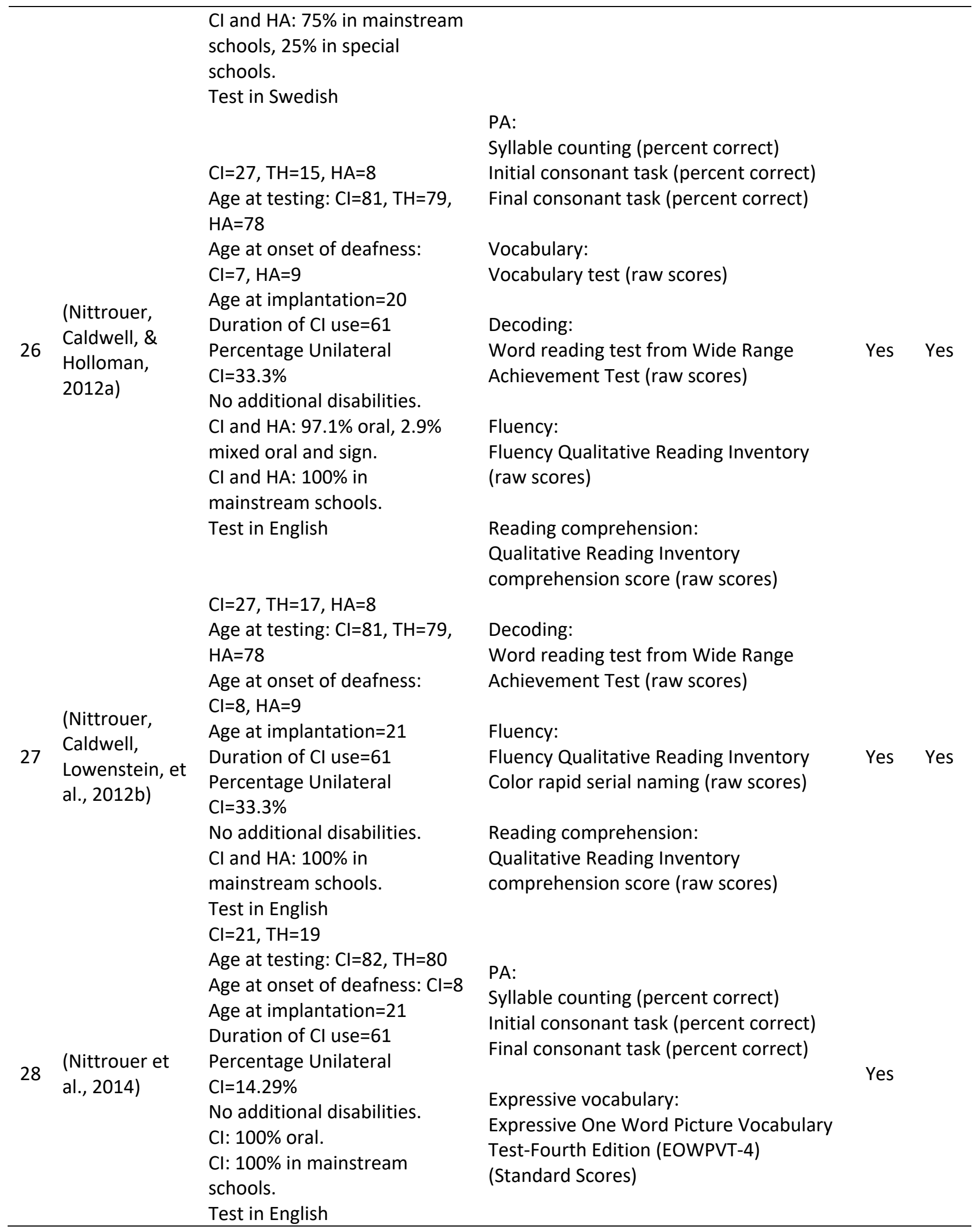




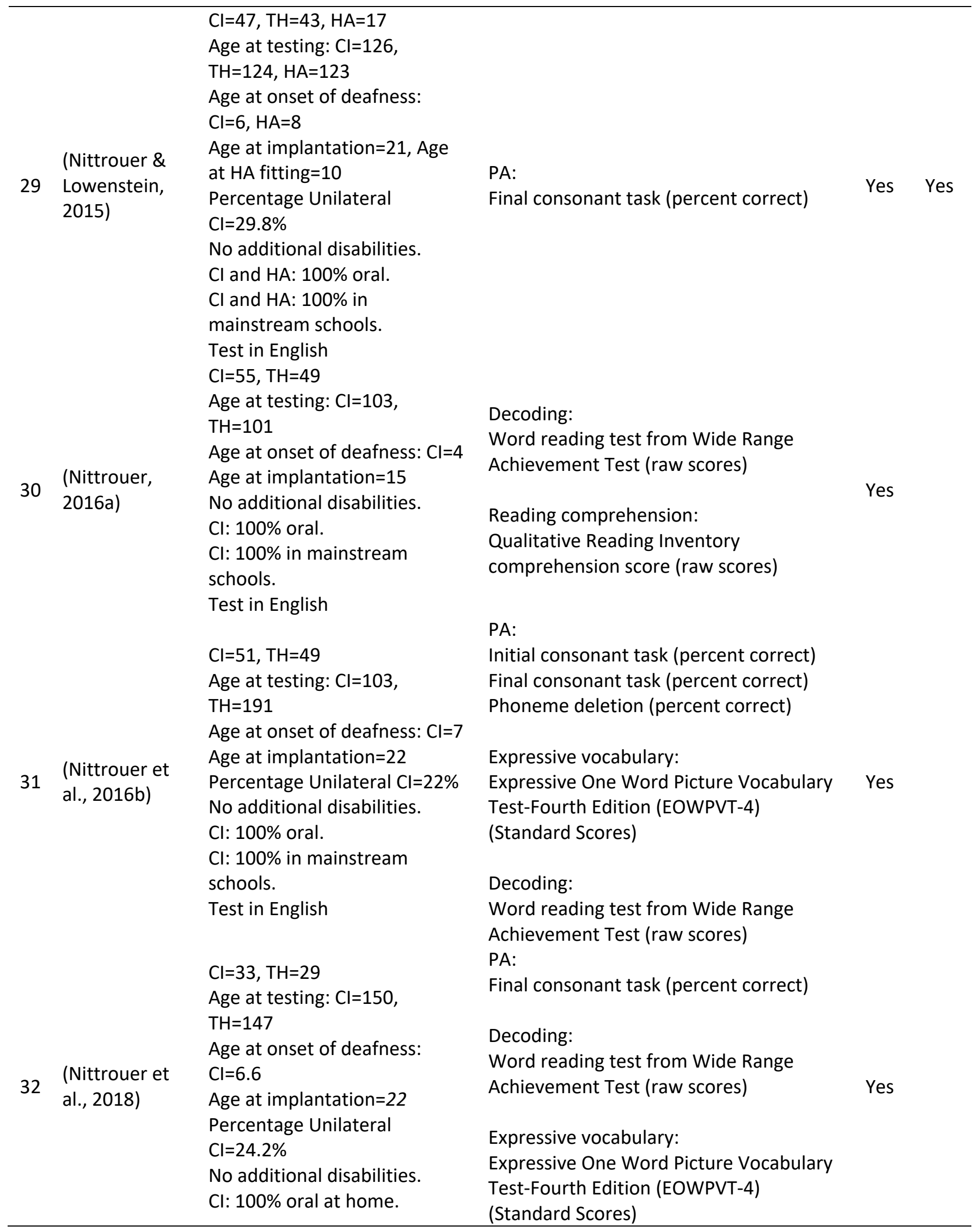




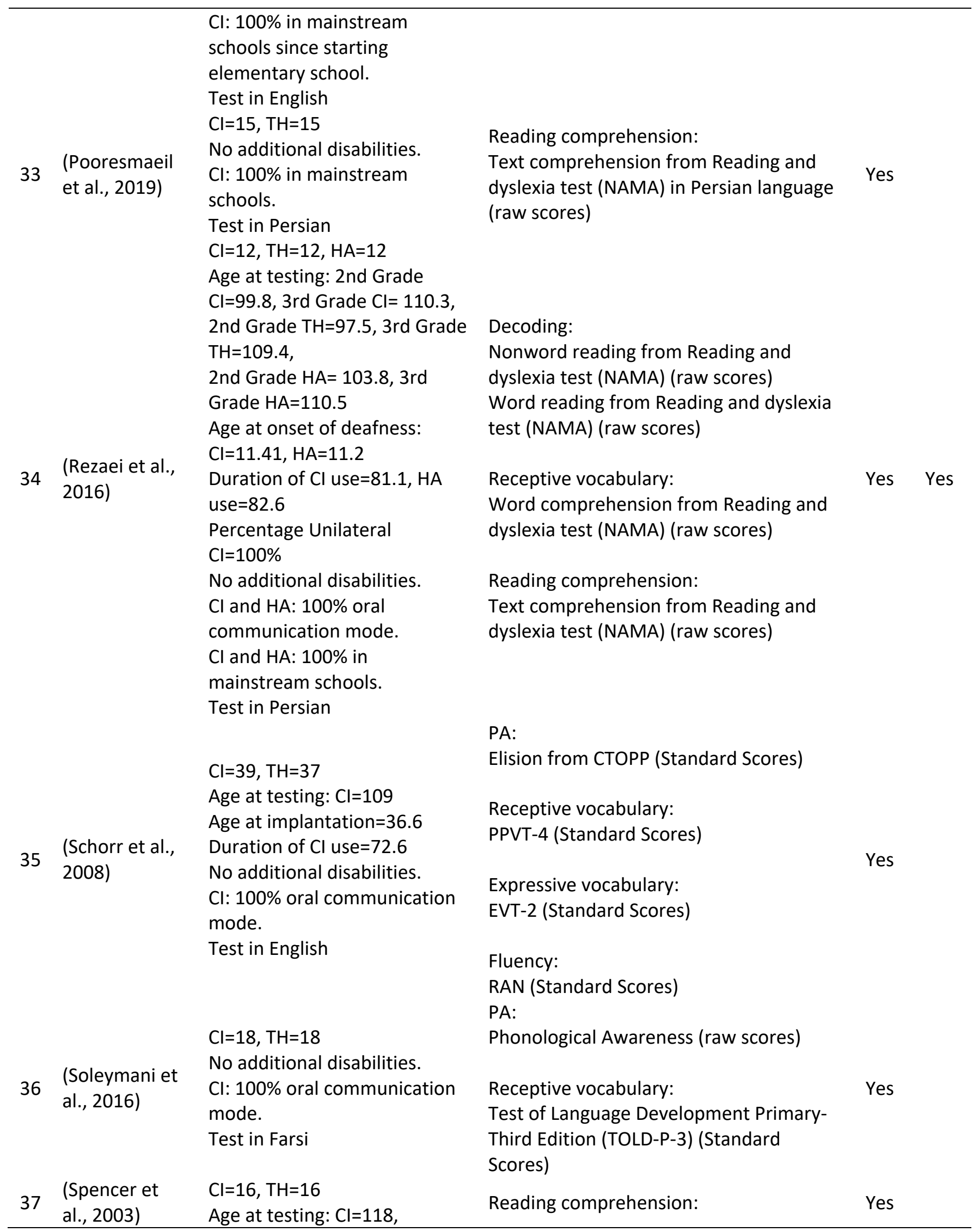


38

(Torres et al.,

39

(Tse \& So, 2012)

40 (Unterstein,
2010)

41

(van der Kant

et al., 2010)
$\mathrm{TH}=118$

Age at implantation $=47$

Duration of $\mathrm{Cl}$ use $=71$

$\mathrm{Cl}: 100 \%$ total communication

mode.

$\mathrm{Cl}: 100 \%$ in mainstream

schools.

Test in English

$\mathrm{Cl}=4, \mathrm{TH}=30$

Age at testing: $\mathrm{Cl}=152.4$,

$\mathrm{TH}=158.4$

Age at onset of deafness:

$\mathrm{Cl}=10$

Age at implantation $=50.1$

No additional disabilities.

Cl: $100 \%$ cued speech.

Test in Spanish

$\mathrm{Cl}=15, \mathrm{TH}=15$

Age at testing: $\mathrm{Cl}=61.9$

Age at onset of deafness:

$\mathrm{Cl}=9.3$

Duration of $\mathrm{Cl}$ use $=37.3$

No additional disabilities.

Test in Cantonese

$\mathrm{Cl}=9, \mathrm{TH}=35$

Age at testing: $\mathrm{Cl}=59.4$,

$\mathrm{TH}=58.3$

Age at onset of deafness:

$\mathrm{Cl}=8.8$

Age at implantation $=19.2$

Percentage Unilateral

$\mathrm{Cl}=22.2 \%$

No additional disabilities.

$\mathrm{Cl}: 100 \%$ oral communication

mode.

CI: $100 \%$ in special preschool

program.

Test in English

$\mathrm{Cl}=44, \mathrm{HA}=30$

Age at testing: $\mathrm{Cl}=124.6$,

$\mathrm{HA}=127$

Age at implantation $=48$

Duration of $\mathrm{Cl}$ use $=76.2$

No additional disabilities.

$\mathrm{Cl}: 100 \%$ oral or sign

supported communication mode.
Passage comprehension from WRMT

(Standard Scores)

Reading comprehension:

Text comprehension from PROLEC-SE Yes

(Ramos and Cuetos, 1999) (raw scores)

PA:

Syllable counting (percent correct)

Syllable deletion (percent correct)

Phoneme detection (percent correct)

Phoneme identification (percent correct)

Yes

Phoneme production (percent correct)

Rhyme detection (percent correct)

Rhyme production (percent correct)

Receptive vocabulary:

PPVT-4 (Standard Scores)

Expressive vocabulary:

Yes 
$\mathrm{Cl}$ and $\mathrm{HA}: 47 \%$ in mainstream

schools, $52 \%$ in special

schools.

Test in Dutch

$\mathrm{Cl}=8, \mathrm{TH}=71$ to 554

Age at onset of deafness:

$\mathrm{Cl}=13$

Age at implantation $=74$

No learning disorders.

42

(Vermeulen et

al., 2007)

(Walker \&

43 McGregor, 2013)

44 (Wass et al., 2008)

45

(Wechsler-
Kashi, 2010)
$\mathrm{Cl}: 48 \%$ total communication mode, $52 \%$ sign-supported Dutch.

$\mathrm{Cl}: 48 \%$ in mainstream

schools, $52 \%$ in special

schools.

Test in Dutch

$\mathrm{Cl}=24, \mathrm{TH}=24$

Age at testing: $\mathrm{Cl}=58.3$,

$\mathrm{TH}=58.6$

Age at implantation $=20.2$

Duration of $\mathrm{Cl}$ use $=37.9$

Percentage Unilateral $\mathrm{Cl}=45.8$

No additional disabilities.

$\mathrm{Cl}: 100 \%$ oral communication

mode.

Test in English

$\mathrm{Cl}=18, \mathrm{TH}=18$

Age at testing: $\mathrm{Cl}=108$

Age at onset of deafness:

$\mathrm{Cl}=17$

Age at implantation $=40$

Duration of $\mathrm{Cl}$ use $=65$

Percentage Unilateral

$\mathrm{Cl}=36.8 \%$

No intellectual disability.

$\mathrm{Cl}: 100 \%$ oral communication mode.

$\mathrm{Cl}: 55.6 \%$ in mainstream

schools, $44.4 \%$ in special

schools.

Test in Swedish

$\mathrm{Cl}=20, \mathrm{TH}=20$

Age at testing: $\mathrm{Cl}=103$,

$\mathrm{TH}=103$

Age at onset of deafness:

$\mathrm{Cl}=12.6$

Age at implantation $=4.9$
Decoding:

Visual word recognition (raw scores)

Yes

Receptive Vocabulary:

PPVT-4 (Standard Scores)

Yes

Decoding:

Nonword discrimination (percent correct)

Receptive Vocabulary:

Yes

Passive naming task (percent correct)
Receptive Vocabulary:

Picture Naming (percent correct)
Yes 


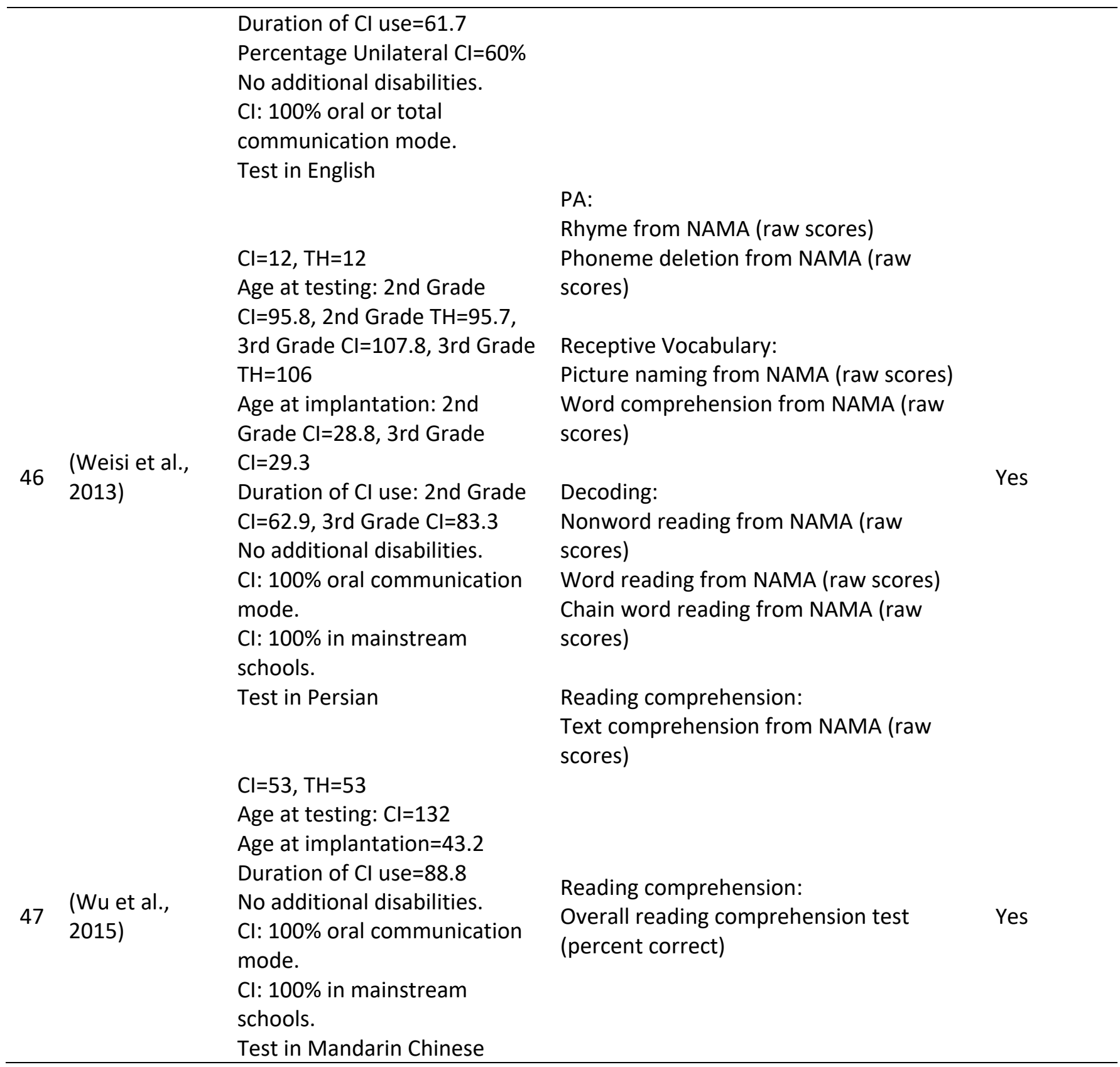

All 47 articles included in the current meta-analysis

Reference List

Ambrose, S. E. (2009). Phonological awareness development of preschool children with cochlear implants (Order No. 854555347) [Doctoral disertation, University of Kansas]. ProQuest Dissertations and Theses Global.

Arrington, L. M. (2018). An Investigation of the Cognitive Profile of Deaf and Hard of Hearing Students on the Wechsler Intelligence Scale for Children-Fifth Edition (Order No. 2121198601) [Doctoral disertation, Texas Woman's University]. ProQuest Dissertations and Theses Global.

Asker-Árnason, L., Wass, M., Gustafsson, F., \& Sahlén, B. (2015). Reading comprehension and working memory capacity in children with hearing loss and cochlear implants or hearing aids. The Volta Review, 115(1), 35-65. 
medRxiv preprint doi: https://doi.org/10.1101/2021.03.02.21252684; this version posted March 27, 2021. The copyright holder for this preprint (which was not certified by peer review) is the author/funder, who has granted medRxiv a license to display the preprint in perpetuity.

All rights reserved. No reuse allowed without permission.

https://www.ingentaconnect.com/content/agbell/vr/2015/00000115/00000001/art00002

Bell, N., Angwin, A. J., Wilson, W. J., \& Arnott, W. L. (2019). Reading development in children with cochlear implants who communicate via spoken language: A psycholinguistic investigation. Journal of Speech, Language, and Hearing Research, 62(2), 456-469. https://doi.org/10.1044/2018_JSLHR$\mathrm{H}-17-0469$

Bouton, S., Bertoncini, J., Serniclaes, W., \& Colé, P. (2011). Reading and reading-related skills in children using cochlear implants: Prospects for the influence of cued speech. Journal of Deaf Studies and Deaf Education, 16(4), 458-473. https://doi.org/10.1093/deafed/enr014

Caselli, M. C., Rinaldi, P., Varuzza, C., Giuliani, A., Burdo, S., Cristina, C. M., Pasquale, R., Cristiana, V., Anna, G., Sandro, B., Caselli, M. C., Rinaldi, P., Varuzza, C., Giuliani, A., Burdo, S., Cristina, C. M., Pasquale, R., Cristiana, V., Anna, G., \& Sandro, B. (2012). Cochlear Implant in the Second Year of Life: Lexical and Grammatical Outcomes. Journal of Speech, Language, and Hearing Research, 55(2), 382-394. https://doi.org/10.1044/1092-4388(2011/10-0248)

Ching, T. Y. C., \& Cupples, L. (2015). Phonological Awareness at 5 years of age in Children who use Hearing Aids or Cochlear Implants. Perspect Hear Hear Disord Child, 25(2), 48-59. https://doi.org/10.1044/hhdc25.2.48

Çizmeci, H., \& Çiprut, A. (2018). Evaluation of gap filling skills and reading mistakes of cochlear implanted and normally hearing students. International Journal of Pediatric Otorhinolaryngology, 109(March), 27-30. https://doi.org/10.1016/j.ijporl.2018.03.014

Çizmeci, H., Çiprut, A., Cizmeci, H., \& Ciprut, A. (2018). Evaluation of the reading and writing skills of children with cochlear implants. Journal of International Advanced Otology, 14(3), 359-364. https://doi.org/10.5152/iao.2018.4436

Convertino, C., Borgna, G., Marschark, M., \& Durkin, A. (2014). Word and world knowledge among deaf learners with and without cochlear implants. Journal of Deaf Studies and Deaf Education, 19(4), 471-483. https://doi.org/10.1093/deafed/enu024

Conway, C. M., Pisoni, D. B., Anaya, E. M., Karpicke, J., \& Henning, S. C. (2011). Implicit sequence learning in deaf children with cochlear implants. Developmental Science, 14(1), 69-82. https://doi.org/10.1111/j.1467-7687.2010.00960.x

Davidson, L. S., Geers, A. E., \& Nicholas, J. G. (2014). The effects of audibility and novel word learning ability on vocabulary level in children with cochlear implants. Cochlear Implants International, 15(4), 211-221. https://doi.org/10.1179/1754762813Y.0000000051

Gallego, C., Martin-Aragoneses, M. T., Lopez-Higes, R., \& Pison, G. (2016). Semantic and syntactic reading comprehension strategies used by deaf children with early and late cochlear implantation. Res Dev Disabil, 49-50, 153-170. https://doi.org/10.1016/j.ridd.2015.11.020

Harris, M., \& Terlektsi, E. (2011). Reading and spelling abilities of deaf adolescents with cochlear implants and hearing aids. Journal of Deaf Studies and Deaf Education, 16(1), 24-34. https://doi.org/10.1093/deafed/enq031

Henricson, C., Wass, M., Lidestam, B., Moller, C., \& Lyxell, B. (2012). Cognitive skills in children with Usher syndrome type 1 and cochlear implants. International Journal of Pediatric Otorhinolaryngology, 76(10), 1449-1457. https://doi.org/10.1016/j.ijporl.2012.06.020

Huber, M., \& Kipman, U. (2012). Cognitive skills and academic achievement of deaf children with cochlear implants. Otolaryngology--Head and Neck Surgery : Official Journal of American Academy of Otolaryngology-Head and Neck Surgery, 147(4), 763-772.

https://doi.org/10.1177/0194599812448352

James, D. M. (2002). The impact of cochlear implantation on phonological awareness in deaf children (Vol. U642641) [University of London, University College London (United Kingdom)]. https://search.proquest.com/docview/1732150914?accountid=8116

Johnson, C., \& Goswami, U. (2010). Phonological awareness, vocabulary, and reading in deaf children 
medRxiv preprint doi: https://doi.org/10.1101/2021.03.02.21252684; this version posted March 27, 2021. The copyright holder for this preprint (which was not certified by peer review) is the author/funder, who has granted medRxiv a license to display the preprint in perpetuity. All rights reserved. No reuse allowed without permission.

with cochlear implants. Journal of Speech, Language, and Hearing Research, 53(2), 237-261. https://doi.org/10.1044/1092-4388(2009/08-0139)

Law, Z. W. Y., \& So, L. K. H. (2006). Phonological abilities of hearing-impaired Cantonese-speaking children with cochlear implants or hearing aids. Journal of Speech, Language, and Hearing Research, 49(6), 1342-1353. https://doi.org/10.1044/1092-4388(2006/096)

Lee, Y., Sung, J. E., \& Sim, H. (2018). Passive sentence comprehension difficulties and its related factors in children with cochlear implants. International Journal of Pediatric Otorhinolaryngology, 109, 60 66. https://doi.org/10.1016/j.ijporl.2018.03.025

Lee, Y., Yim, D., \& Sim, H. (2012). Phonological processing skills and its relevance to receptive vocabulary development in children with early cochlear implantation. International Journal of Pediatric Otorhinolaryngology, 76(12), 1755-1760. https://doi.org/10.1016/j.ijporl.2012.08.016

Löfkvist, U., Almkvist, O., Lyxell, B., \& Tallberg, I. M. (2014). Lexical and semantic ability in groups of children with cochlear implants, language impairment and autism spectrum disorder. International Journal of Pediatric Otorhinolaryngology, 78(2), 253-263. https://doi.org/10.1016/j.ijporl.2013.11.017

Luckhurst, J. A., Lauback, C. W., \& VanSkiver, A. R. U. (2013). Differences in spoken lexical skills: Preschool children with cochlear implants and children with typical hearing. The Volta Review, 113(1), 29-42. https://doi.org/10.17955/tvr.113.1.729

Mandal, J. C., Kumar, S., \& Roy, S. (2016). Comparison of auditory comprehension skills in children with cochlear implant and typically developing children. International Journal of Pediatric Otorhinolaryngology, 91, 113-120. https://doi.org/10.1016/j.ijporl.2016.10.009

Nakeva von Mentzer, C., Lyxell, B., Sahlen, B., Wass, M., Lindgren, M., Ors, M., Kallioinen, P., \& Uhlen, I. (2013). Computer-assisted training of phoneme-grapheme correspondence for children who are deaf and hard of hearing: effects on phonological processing skills. International Journal of Pediatric Otorhinolaryngology, 77(12), 2049-2057. https://doi.org/10.1016/j.ijporl.2013.10.007

Nittrouer, S. (2016a). Beyond Early Intervention: Supporting Children With Cls Through Elementary School. Otology \& Neurotology : Official Publication of the American Otological Society, American Neurotology Society [and] European Academy of Otology and Neurotology, 37(2), e43-9. https://doi.org/10.1097/MAO.0000000000000906

Nittrouer, S., Caldwell-Tarr, A., Sansom, E., Twersky, J., \& Lowenstein, J. H. (2014). Nonword repetition in children with cochlear implants: A potential clinical marker of poor language acquisition. American Journal of Speech-Language Pathology, 23(4), 679-695. https://doi.org/10.1044/2014_AJSLP-140040

Nittrouer, S., Caldwell, A., \& Holloman, C. (2012a). Measuring what matters: effectively predicting language and literacy in children with cochlear implants. International Journal of Pediatric Otorhinolaryngology, 76(8), 1148-1158. https://doi.org/10.1016/j.ijporl.2012.04.024

Nittrouer, S., Caldwell, A., Lowenstein, J. H., Tarr, E., \& Holloman, C. (2012b). Emergent literacy in kindergartners with cochlear implants. Ear and Hearing, 33(6), 683. https://doi.org/10.1097/AUD.0b013e318258c98e

Nittrouer, S., \& Lowenstein, J. H. (2015). Weighting of Acoustic Cues to a Manner Distinction by Children with and without Hearing Loss. Journal of Speech, Language, and Hearing Research, 58(3), 10771092. https://doi.org/http://dx.doi.org/10.1044/2015_JSLHR-H-14-0263

Nittrouer, S., Lowenstein, J. H., \& Holloman, C. (2016b). Early predictors of phonological and morphosyntactic skills in second graders with cochlear implants. Research in Developmental Disabilities, 55, 143-160. https://doi.org/10.1016/j.ridd.2016.03.020

Nittrouer, S., Muir, M., Tietgens, K., Moberly, A. C., \& Lowenstein, J. H. (2018). Development of phonological, lexical, and syntactic abilities in children with cochlear implants across the elementary grades. Journal of Speech, Language, and Hearing Research, 61(10), 2561-2577. 
medRxiv preprint doi: https://doi.org/10.1101/2021.03.02.21252684; this version posted March 27, 2021. The copyright holder for this preprint (which was not certified by peer review) is the author/funder, who has granted medRxiv a license to display the preprint in perpetuity.

All rights reserved. No reuse allowed without permission.

https://doi.org/10.1044/2018_JSLHR-H-18-0047

Pooresmaeil, E., Mohamadi, R., Ghorbani, A., \& Kamali, M. (2019). The relationship between comprehension of syntax and reading comprehension in cochlear implanted and hearing children. International Journal of Pediatric Otorhinolaryngology, 121(March), 114-119. https://doi.org/10.1016/j.ijporl.2019.03.004

Rezaei, M., Rashedi, V., \& Morasae, E. K. (2016). Reading skills in Persian deaf children with cochlear implants and hearing aids. International Journal of Pediatric Otorhinolaryngology, 89, 1-5. https://doi.org/10.1016/j.ijporl.2016.07.010

Schorr, E. A., Roth, F. P., \& Fox, N. A. (2008). A Comparison of the Speech and Language Skills of Children With Cochlear Implants and Children With Normal Hearing. Communication Disorders Quarterly, 29(4), 195-210. https://doi.org/10.1177/1525740108321217

Soleymani, Z., Mahmoodabadi, N., \& Nouri, M. M. (2016). Language skills and phonological awareness in children with cochlear implants and normal hearing. International Journal of Pediatric Otorhinolaryngology, 83, 16-21. https://doi.org/10.1016/j.ijporl.2016.01.013

Spencer, L. J., Barker, B. A., \& Tomblin, J. B. (2003). Exploring the language and literacy outcomes of pediatric cochlear implant users. Ear and Hearing, 24(3), 236-247. https://doi.org/10.1097/01.AUD.0000069231.72244.94

Torres, S., Rodríguez, J. M., García-Orza, J., \& Calleja, M. (2008). Reading comprehension of an inferential text by deaf students with cochlear implants using cued speech. The Volta Review, 108(1), 37-57. https://www.agbell.org/Portals/26/VoltaReview/108-1.pdf

Tse, W. T., \& So, L. K. H. (2012). Phonological awareness of Cantonese-speaking pre-school children with cochlear implants. International Journal of Speech-Language Pathology, 14(1), 73-83. https://doi.org/10.3109/17549507.2011.604428

Unterstein, A. P. (2010). Examining the differences in expressive and receptive lexical language skills in preschool children with cochlear implants and children with typical hearing (Order No. 516278593) [Doctoral disertation, Alfred University]. ProQuest Dissertations and Theses Global.

van der Kant, A., Vermeulen, A., Raeve, L. De, \& Schreuder, R. (2010). Reading comprehension of flemish deaf children in belgium: Sources of variability in reading comprehension after cochlear implantation. Deafness and Education International, 12(2), 77-98. https://doi.org/10.1179/146431510X12626982043769

Vermeulen, A. M., van Bon, W., Schreuder, R., Knoors, H., \& Snik, A. (2007). Reading comprehension of deaf children with cochlear implants. Journal of Deaf Studies and Deaf Education, 12(3), 283-302. https://doi.org/10.1093/deafed/enm017

Walker, E. A., \& McGregor, K. K. (2013). Word learning processes in children with cochlear implants. Journal of Speech, Language, and Hearing Research, 56(2), 375-387. https://doi.org/10.1044/1092-4388(2012/11-0343)

Wass, M., Ibertsson, T., Lyxell, B., Sahlen, B., Hallgren, M., LARSBY, B., \& Maki-torkko, E. (2008). Cognitive and linguistic skills in Swedish children with cochlear implants - measures of accuracy and latency as indicators of development. Scandinavian Journal of Psychology, 49(6), 559-576. https://doi.org/10.1111/j.1467-9450.2008.00680.x

Wechsler-Kashi, D. (2010). Lexical processing during naming in children with cochlear implants (Order No. 763608143) [Doctoral disertation, City University of New York]. ProQuest Dissertations and Theses Global.

Weisi, F., Rezaei, M., Rashedi, V., Heidari, A., Valadbeigi, A., \& Ebrahimi-Pour, M. (2013). Comparison of reading skills between children with cochlear implants and children with typical hearing in Iran. International Journal of Pediatric Otorhinolaryngology, 77(8), 1317-1321. https://doi.org/10.1016/j.ijporl.2013.05.023

Wu, C.-M., Lee, L.-A., Chao, W.-C., Tsou, Y.-T., \& Chen, Y.-A. (2015). Paragraph-reading comprehension 
medRxiv preprint doi: https://doi.org/10.1101/2021.03.02.21252684; this version posted March 27, 2021. The copyright holder for this preprint (which was not certified by peer review) is the author/funder, who has granted medRxiv a license to display the preprint in perpetuity.

All rights reserved. No reuse allowed without permission.

ability in Mandarin-speaking children with cochlear implants. The Laryngoscope, 125(6), 14491455. https://doi.org/10.1002/lary.25081 


\section{Supplementary Table A.3 All 61 articles excluded after full-text screening in the current study}

\begin{tabular}{|c|c|c|}
\hline$\#$ & Study & Reason for exclusion \\
\hline 1 & (Apel \& Masterson, 2015) & Comparison groups were not age-matched \\
\hline 2 & (Eisenberg et al., 2004) & Comparison groups were not age-matched \\
\hline 3 & (Fitzpatrick et al., 2012) & Comparison groups were not age-matched \\
\hline 4 & (Harris et al., 2017) & Comparison groups were not age-matched \\
\hline 5 & (Jung, 2015) & Comparison groups were not age-matched \\
\hline 6 & (Oktapoti et al., 2016) & Comparison groups were not age-matched \\
\hline 7 & (Spencer \& Tomblin, 2009) & Comparison groups were not age-matched \\
\hline 8 & (Connor \& Zwolan, 2004) & No comparison group \\
\hline 9 & (Dillon et al., 2012) & No comparison group \\
\hline 10 & (Geers \& Hayes, 2011) & No comparison group \\
\hline 11 & (Hayes et al., 2009) & No comparison group \\
\hline 12 & (Lu et al., 2013) & No comparison group \\
\hline 13 & (Spencer et al., 1997) & No comparison group \\
\hline 14 & (Tomblin et al., 2000) & No comparison group \\
\hline 15 & (Wang et al., 2018) & No comparison group \\
\hline 16 & (Lund \& Schuele, 2017) & Age range was outside of 3-18 years old \\
\hline 17 & (Lyxell et al., 1998) & Age range was outside of $3-18$ years old \\
\hline 18 & (Moberly et al., 2017) & Age range was outside of 3-18 years old \\
\hline 19 & (Nicholas \& Geers, 2018) & Age range was outside of $3-18$ years old \\
\hline 20 & (Pisoni et al., 2018) & Age range was outside of $3-18$ years old \\
\hline 21 & (Schramm et al., 2010) & Age range was outside of $3-18$ years old \\
\hline 22 & (Boons et al., 2013) & Participants with other conditions \\
\hline 23 & (Cupples et al., 2018) & Participants with other conditions \\
\hline 24 & (Holt et al., 2019) & Participants with other conditions \\
\hline 25 & (Kunisue et al., 2007) & Participants with other conditions \\
\hline 26 & (Percy-Smith et al., 2018) & Participants with other conditions \\
\hline 27 & (Arya et al., 2019) & Did not collect reading skills fitting into the five constructs \\
\hline 28 & (Aubuchon et al., 2015) & Did not collect reading skills fitting into the five constructs \\
\hline 29 & (Crosson \& Geers, 2001) & Did not collect reading skills fitting into the five constructs \\
\hline 30 & (Cupples et al., 2014) & Did not collect reading skills fitting into the five constructs \\
\hline 31 & (Smith et al., 2019) & Did not collect reading skills fitting into the five constructs \\
\hline 32 & (Werfel et al., 2015) & Did not collect reading skills fitting into the five constructs \\
\hline 33 & (Brouwer et al., 2017) & Case studies \\
\hline 34 & (Martins et al., 2018) & Case studies \\
\hline 35 & (Werfel et al., 2016) & Case studies \\
\hline 36 & (Blamey et al., 2001) & Authors indicated data unavailable \\
\hline 37 & (Surowiecki et al., 2002) & Authors indicated data unavailable \\
\hline 38 & (Dominguez et al., 2019) & No response from authors \\
\hline 39 & (Iwasaki et al., 2012) & No response from authors \\
\hline 40 & (Lyxell et al., 2008) & No response from authors \\
\hline 41 & (Lyxell et al., 2011) & No response from authors \\
\hline 42 & (Mey et al., 2019) & No response from authors \\
\hline 43 & (Rastegarianzadeh et al., 2014) & No response from authors \\
\hline
\end{tabular}




\begin{tabular}{|c|c|c|}
\hline 44 & (Scott et al., 2019) & No response from authors \\
\hline 45 & (Yoshinaga-Itano et al., 2010) & No response from authors \\
\hline 46 & (Jing et al., 2019) & Non-parametric effects \\
\hline 47 & (Ostojic et al., 2011) & Non-parametric effects \\
\hline 48 & (Fairgray et al., 2010) & No $\mathrm{Cl}$ group \\
\hline 49 & (Herman et al., 2019) & No $\mathrm{Cl}$ group \\
\hline 50 & (Werfel, 2017) & No $\mathrm{Cl}$ group \\
\hline 51 & (Harris et al., 2017) & $\mathrm{Cl}$ and $\mathrm{HA}$ groups were combined as deaf children \\
\hline 52 & (Kyle et al., 2016) & $\mathrm{Cl}$ and $\mathrm{HA}$ groups were combined as deaf children \\
\hline 53 & (Ambrose et al., 2012) & $\begin{array}{l}\text { Data from the same group of researchers whose articles have } \\
\text { already been included }\end{array}$ \\
\hline 54 & (Asker-Árnason et al., 2007) & $\begin{array}{l}\text { Data from the same group of researchers whose articles have } \\
\text { already been included }\end{array}$ \\
\hline 55 & (Bouton et al., 2015) & $\begin{array}{l}\text { Data from the same group of researchers whose articles have } \\
\text { already been included }\end{array}$ \\
\hline 56 & (James et al., 2009) & $\begin{array}{l}\text { Data from the same group of researchers whose articles have } \\
\text { already been included }\end{array}$ \\
\hline 57 & (James et al., 2005) & $\begin{array}{l}\text { Data from the same group of researchers whose articles have } \\
\text { already been included }\end{array}$ \\
\hline 58 & (López-Higes et al., 2015) & $\begin{array}{l}\text { Data from the same group of researchers whose articles have } \\
\text { already been included }\end{array}$ \\
\hline 59 & (Nittrouer et al., 2014) & $\begin{array}{l}\text { Data from the same group of researchers whose articles have } \\
\text { already been included }\end{array}$ \\
\hline 60 & (Wass, 2009) & $\begin{array}{l}\text { Data from the same group of researchers whose articles have } \\
\text { already been included }\end{array}$ \\
\hline 61 & (Wechsler-Kashi et al., 2014) & $\begin{array}{l}\text { Data from the same group of researchers whose articles have } \\
\text { already been included }\end{array}$ \\
\hline
\end{tabular}

All 61 articles excluded after full-text screening of 104 articles in the current study

Reference List

Ambrose, S. E., Fey, M. E., \& Eisenberg, L. S. (2012). Phonological awareness and print knowledge of preschool children with cochlear implants. Journal of Speech, Language, and Hearing Research, 55(3), 811-823. https://doi.org/10.1044/1092-4388(2011/11-0086)

Apel, K., \& Masterson, J. J. (2015). Comparing the spelling and reading abilities of students with cochlear implants and students with typical hearing. Journal of Deaf Studies and Deaf Education, 20(2), 125135. https://doi.org/10.1093/deafed/env002

Arya, R., Nandurkar, A., Shah, M., \& Verma, N. (2019). Speech Perception Skills of Hindi Speaking Children with Pre-lingual Hearing Loss Using Hearing Aids and Cochlear Implants. Indian Journal of Otolaryngology and Head and Neck Surgery: Official Publication of the Association of Otolaryngologists of India, 71(Suppl 2), 1241-1247. https://doi.org/10.1007/s12070-018-1291-x

Asker-Árnason, L., Wass, M., Ibertsson, T., Lyxell, B., \& Sahlén, B. (2007). The relationship between reading comprehension, working memory and language in children with cochlear implants. Acta Neuropsychologica, 5(4), 163-186.

Aubuchon, A. M., Pisoni, D. B., \& Kronenberger, W. G. (2015). Verbal processing speed and executive functioning in Long-Term cochlear implant users. Journal of Speech, Language, and Hearing Research, 58(1), 151-162. https://doi.org/10.1044/2014_JSLHR-H-13-0259

Blamey, P. J., Sarant, J. Z., Paatsch, L. E., Barry, J. G., Bow, C. P., Wales, R. J., Wright, M., Psarros, C., Rattigan, K., \& Tooher, R. (2001). Relationships among speech perception, production, language, 
medRxiv preprint doi: https://doi.org/10.1101/2021.03.02.21252684; this version posted March 27, 2021. The copyright holder for this preprint (which was not certified by peer review) is the author/funder, who has granted medRxiv a license to display the preprint in perpetuity.

All rights reserved. No reuse allowed without permission.

hearing loss, and age in children with impaired hearing. Journal of Speech, Language, and Hearing Research : JSLHR, 44(2), 264-285. https://doi.org/10.1044/1092-4388(2001/022)

Boons, T., de Raeve, L., Langereis, M., Peeraer, L., Wouters, J., \& van Wieringen, A. (2013). Expressive vocabulary, morphology, syntax and narrative skills in profoundly deaf children after early cochlear implantation. Research in Developmental Disabilities, 34(6), 2008-2022. https://doi.org/10.1016/j.ridd.2013.03.003

Bouton, S., Colé, P., Serniclaes, W., Duncan, L. G., \& Giraud, A.-L. L. (2015). Atypical phonological processing impairs written word recognition in children with cochlear implants. Language, Cognition and Neuroscience, 30(6), 684-699. https://doi.org/10.1080/23273798.2014.1002796

Brouwer, K., Downing, H., Westhoff, S., Wait, R., Entwisle, L. K., Messersmith, J. J., \& Hanson, E. K. (2017). Effects of clinician-guided emergent literacy intervention using interactive tablet technology for preschool children with cochlear implants. Communication Disorders Quarterly, 38(4), 195-205. https://doi.org/10.1177/1525740116666040

Connor, C. M., \& Zwolan, T. A. (2004). Examining Multiple Sources of Influence on the Reading Comprehension Skills of Children Who Use Cochlear Implants. Journal of Speech, Language, and Hearing Research, 47(3), 18-509. https://search.proquest.com/docview/62124620?accountid=8116

Crosson, J., \& Geers, A. (2001). Analysis of narrative ability in children with cochlear implants. Ear and Hearing, 22(5), 381-394. https://doi.org/10.1097/00003446-200110000-00003

Cupples, L., Ching, T. Y. C., Button, L., Seeto, M., Zhang, V., Whitfield, J., Gunnourie, M., Martin, L., \& Marnane, V. (2018). Spoken language and everyday functioning in 5-year-old children using hearing aids or cochlear implants. International Journal of Audiology, 57(Suppl 2), S55-S69. https://doi.org/10.1080/14992027.2017.1370140

Cupples, L., Ching, T. Y. C., Crowe, K., Day, J., \& Seeto, M. (2014). Predictors of early reading skill in 5year-old children with hearing loss who use spoken language. Reading Research Quarterly, 49(1), 85-104.

http://libproxy.unl.edu/login?url=http://search.ebscohost.com/login.aspx?direct=true\&db=psyh\& AN=2014-00054-004\&site=ehost-live

Dillon, C. M., de Jong, K., \& Pisoni, D. B. (2012). Phonological awareness, reading skills, and vocabulary knowledge in children who use cochlear implants. J Deaf Stud Deaf Educ, 17(2), 205-226. https://doi.org/10.1093/deafed/enr043

Dominguez, A.-B., Alegria, J., Carrillo, M.-S., \& Gonzalez, V. (2019). Learning to Read for SpanishSpeaking Deaf Children With and Without Cochlear Implants: The Role of Phonological and Orthographic Representation. American Annals of the Deaf, 164(1), 37-72. https://doi.org/10.1353/aad.2019.0009

Eisenberg, L. S., Kirk, K. I., Martinez, A. S., Ying, E. A., \& Miyamoto, R. T. (2004). Communication abilities of children with aided residual hearing: comparison with cochlear implant users. Archives of Otolaryngology - Head and Neck Surgery, 130(5), 563-569. https://doi.org/10.1001/archotol.130.5.563

Fairgray, E., Purdy, S. C., \& Smart, J. L. (2010). Effects of auditory-verbal therapy for school-aged children with hearing loss: An exploratory study. The Volta Review, 110(3), 407-433. http://libproxy.unl.edu/login?url=http://search.ebscohost.com/login.aspx?direct=true\&db=psyh\& AN=2011-00180-003\&site=ehost-live

Fitzpatrick, E. M., Olds, J., Gaboury, I., McCrae, R., Schramm, D., \& Durieux-Smith, A. (2012). Comparison of outcomes in children with hearing aids and cochlear implants. Cochlear Implants International: An Interdisciplinary Journal, 13(1), 5-15. https://doi.org/10.1179/146701011X12950038111611

Geers, A. E., \& Hayes, H. (2011). Reading, writing, and phonological processing skills of adolescents with 10 or more years of cochlear implant experience. Ear and Hearing, 32(1 Suppl), 49s-59s. 
medRxiv preprint doi: https://doi.org/10.1101/2021.03.02.21252684; this version posted March 27, 2021. The copyright holder for this preprint (which was not certified by peer review) is the author/funder, who has granted medRxiv a license to display the preprint in perpetuity.

All rights reserved. No reuse allowed without permission.

https://doi.org/10.1097/aud.0b013e3181fa41fa

Harris, M., Terlektsi, E., \& Kyle, F. E. (2017). Concurrent and longitudinal predictors of reading for deaf and hearing children in primary school. Journal of Deaf Studies and Deaf Education, 22(2), 233242. https://doi.org/10.1093/deafed/enw101

Hayes, H., Geers, A. E., Treiman, R., \& Moog, J. S. (2009). Receptive vocabulary development in deaf children with cochlear implants: achievement in an intensive auditory-oral educational setting. Ear and Hearing, 30(1), 128-135. https://doi.org/10.1097/AUD.0b013e3181926524

Herman, R., E. Kyle, F., \& Roy, P. (2019). Literacy and phonological skills in oral deaf children and hearing children with a history of dyslexia. Reading Research Quarterly, 54(4), 553-575.

Holt, R. F., Beer, J., Kronenberger, W. G., Pisoni, D. B., Lalonde, K., \& Mulinaro, L. (2019). Family Environment in Children With Hearing Aids and Cochlear Implants Associations With Spoken Language, Psychosocial Functioning, and Cognitive Development. Ear \& Hearing. https://doi.org/10.1097/AUD.0000000000000811

Iwasaki, S., Nishio, S., Moteki, H., Takumi, Y., Fukushima, K., Kasai, N., \& Usami, S.-I. (2012). Language development in Japanese children who receive cochlear implant and/or hearing aid. International Journal of Pediatric Otorhinolaryngology, 76(3), 433-438. https://doi.org/10.1016/j.ijporl.2011.12.027

James, D., Rajput, K., Brinton, J., \& Goswami, U. (2009). Orthographic influences, vocabulary development, and phonological awareness in deaf children who use cochlear implants. Applied Psycholinguistics, 30(4), 659-684. https://doi.org/10.1017/S0142716409990063

James, D., Rajput, K., Brown, T., Sirimanna, T., Brinton, J., \& Goswami, U. (2005). Phonological awareness in deaf children who use cochlear implants. Journal of Speech, Language, and Hearing Research, 48(6), 1511-1528. https://doi.org/10.1044/1092-4388(2005/105)

Jing, L., Vermeire, K., Mangino, A., \& Reuterskiöld, C. (2019). Rhyme awareness in children with normal hearing and children with cochlear implants: An exploratory study. Frontiers in Psychology, 10. https://doi.org/10.3389/fpsyg.2019.02072

Jung, J. (2015). Vocabulary and Grammar in Young Children with Cochlear Implants and Typically Developing Children [ProQuest Information \& Learning]. In ProQuest Dissertations and Theses (Vol. 77, Issues 4-B(E)).

https://search.proquest.com/docview/1747107710?accountid=14548\%0Ahttps://julac.hosted.exli brisgroup.com/openurl/HKU_ALMA/SERVICES_PAGE??url_ver=Z39.88-

2004\&rft_val_fmt=info:ofi/fmt:kev:mtx:dissertation\&genre=dissertations+\%26+theses\&sid=ProQ: ProQuest+Diss

Kunisue, K., Fukushima, K., Kawasaki, A., Maeda, Y., Nagayasu, R., Kataoka, Y., Kariya, S., Fukutomi, Y., Takami, H., \& Nishizaki, K. (2007). Comprehension of abstract words among hearing impaired children. International Journal of Pediatric Otorhinolaryngology, 71(11), 1671-1679. https://doi.org/10.1016/j.ijporl.2007.06.015

Kyle, F. E., Campbell, R., \& MacSweeney, M. (2016). The relative contributions of speechreading and vocabulary to deaf and hearing children's reading ability. Res Dev Disabil, 48, 13-24. https://doi.org/10.1016/j.ridd.2015.10.004

López-Higes, R., Gallego, C., Martín-Aragoneses, M. T., Melle, N., Lopez-Higes, R., Gallego, C., MartinAragoneses, M. T., Melle, N., López-Higes, R., Gallego, C., Martín-Aragoneses, M. T., \& Melle, N. (2015). Morpho-syntactic reading comprehension in children with early and late cochlear implants. Journal of Deaf Studies and Deaf Education, 20(2), 136-146. https://doi.org/10.1093/deafed/env004

Lu, X., Wong, L. L.-N., Wong, A. M.-Y., \& Xi, X. (2013). Development of a Mandarin Expressive and Receptive' Vocabulary Test for children using cochlear implants. Research in Developmental Disabilities, 34(10), 3526-3535. https://doi.org/10.1016/j.ridd.2013.07.010 
medRxiv preprint doi: https://doi.org/10.1101/2021.03.02.21252684; this version posted March 27, 2021. The copyright holder for this preprint (which was not certified by peer review) is the author/funder, who has granted medRxiv a license to display the preprint in perpetuity. All rights reserved. No reuse allowed without permission.

Lund, E., \& Schuele, C. M. (2017). Word-learning performance of children with and without cochlear implants given synchronous and asynchronous cues. Clinical Linguistics \& Phonetics, 31(10), 777790. https://doi.org/10.1080/02699206.2017.1320587

Lyxell, B., Andersson, J., Andersson, U., Arlinger, S., Bredberg, G., \& Harder, H. (1998). Phonological representation and speech understanding with cochlear implants in deafened adults. Scandinavian Journal of Psychology, 39(3), 175-179. https://doi.org/10.1111/1467-9450.393075

Lyxell, B., Sahlén, B., Wass, M., Ibertsson, T., Larsby, B., Hällgren, M., \& Mäki-Torkko, E. (2008). Cognitive development in children with cochlear implants: Relations to reading and communication. International Journal of Audiology, 47(sup2), S47-S52. https://doi.org/10.1080/14992020802307370

Lyxell, B., Wass, M., Sahlén, B., Uhlén, I., Samuelsson, C., Asker-Árnason, L., Ibertsson, T., Mäki-Torkko, E., Larsby, B., \& Hällgren, M. (2011). Development of cognitive and reading skills in deaf children with Cls. Cochlear Implants International, 12(Suppl 1), S98-S100. https://doi.org/10.1179/146701011X13001035752688

Martins, C. I. S., Queiroga, B. A. M. de, Rosal, A. G. C., \& Cordeiro, A. A. de A. (2018). Análise comparativa da avaliação cognitivo-linguística em escolares ouvintes e usuário de implante coclear. CoDAS, 30(4), e20170133. https://doi.org/10.1590/2317-1782/20182017133

Mey, K., Percy-Smith, L., Hallstrom, M., Sandvej, M., \& Caye-Thomasen, P. (2019). Receptive language acquisition in a pediatric population with Pendred syndrome and non-syndromic enlarged vestibular aqueduct. Acta Oto-Laryngologica, 1-5. https://doi.org/10.1080/00016489.2019.1689293

Moberly, A. C., Harris, M. S., Boyce, L., \& Nittrouer, S. (2017). Speech recognition in adults with cochlear implants: The effects of working memory, phonological sensitivity, and aging. Journal of Speech, Language, and Hearing Research, 60(4), 1046-1061. https://doi.org/10.1044/2016_JSLHR-H-160119

Nicholas, J. G., \& Geers, A. E. (2018). Sensitivity of expressive linguistic domains to surgery age and audibility of speech in preschoolers with cochlear implants. Cochlear Implants International, 19(1), 26-37. https://doi.org/10.1080/14670100.2017.1380114

Nittrouer, S., Sansom, E., Low, K., Rice, C., \& Caldwell-Tarr, A. (2014). Language structures used by kindergartners with cochlear implants: relationship to phonological awareness, lexical knowledge and hearing loss. Ear and Hearing, 35(5), 506-518. https://doi.org/10.1097/AUD.0000000000000051

Oktapoti, M., Okalidou, A., Kyriafinis, G., Petinou, K., Vital, V., \& Herman, R. (2016). Investigating Use of a Parent Report Tool to Measure Vocabulary Development in Deaf Greek-Speaking Children with Cochlear Implants. Deafness \& Education International, 18(1), 3-12. https://doi.org/http://dx.doi.org/10.1179/1557069X15Y.0000000008

Ostojic, S., Djokovic, S., Dimic, N., \& Mikic, B. (2011). Cochlear implant--speech and language development in deaf and hard of hearing children following implantation. Vojnosanitetski Pregled, 68(4), 349-352. https://doi.org/10.2298/vsp1104349o

Percy-Smith, L., Hallstrom, M., Josvassen, J. L., Mikkelsen, J. H., Nissen, L., Dieleman, E., \& CayeThomasen, P. (2018). Differences and similarities in early vocabulary development between children with hearing aids and children with cochlear implant enrolled in 3-year auditory verbal intervention. International Journal of Pediatric Otorhinolaryngology, 108, 67-72. https://doi.org/10.1016/j.ijporl.2018.02.030

Pisoni, D. B., Broadstock, A., Wucinich, T., Safdar, N., Miller, K., Hernandez, L. R., Vasil, K., Boyce, L., Davies, A., Harris, M. S., Castellanos, I., Xu, H., Kronenberger, W. G., \& Moberly, A. C. (2018). Verbal Learning and Memory After Cochlear Implantation in Postlingually Deaf Adults: Some New Findings with the CVLT-II. Ear and Hearing, 39(4), 720-745. 
medRxiv preprint doi: https://doi.org/10.1101/2021.03.02.21252684; this version posted March 27, 2021. The copyright holder for this preprint (which was not certified by peer review) is the author/funder, who has granted medRxiv a license to display the preprint in perpetuity.

All rights reserved. No reuse allowed without permission.

https://doi.org/10.1097/AUD.0000000000000530

Rastegarianzadeh, N., Shahbodaghi, M., \& Faghihzadeh, S. (2014). Study of phonological awareness of preschool and school aged children with cochlear implant and normal hearing. Korean Journal of Audiology, 18(2), 50-53. https://doi.org/10.7874/kja.2014.18.2.50

Schramm, B., Bohnert, A., \& Keilmann, A. (2010). Auditory, speech and language development in young children with cochlear implants compared with children with normal hearing. International Journal of Pediatric Otorhinolaryngology, 74(7), 812-819. https://doi.org/10.1016/j.ijporl.2010.04.008

Scott, J. A., Goldberg, H., Connor, C. M., \& Lederberg, A. R. (2019). Schooling effects on early literacy skills of young deaf and hard of hearing children. American Annals of the Deaf, 163(5), 596-618. https://doi.org/10.1353/aad.2019.0005

Smith, G. N. L., Pisoni, D. B., \& Kronenberger, W. G. (2019). High-Variability Sentence Recognition in Long-Term Cochlear Implant Users: Associations With Rapid Phonological Coding and Executive Functioning. Ear and Hearing, 40(5), 1149-1161. https://doi.org/10.1097/AUD.0000000000000691

Spencer, L. J., \& Tomblin, J. B. (2009). Evaluating phonological processing skills in children with prelingual deafness who use cochlear implants. Journal of Deaf Studies and Deaf Education, 14(1), 1-21. https://doi.org/10.1093/deafed/enn013

Spencer, L., Tomblin, J. B., \& Gantz, B. J. (1997). Reading Skills in Children with Multichannel CochlearImplant Experience. The Volta Review, 99(4), 193-202.

Surowiecki, V. N., Sarant, J., Maruff, P., Blamey, P. J., Busby, P. A., \& Clark, G. M. (2002). Cognitive processing in children using cochlear implants: The relationship between visual memory, attention, and executive functions and developing language skills. Annals of Otology, Rhinology and Laryngology, 111(5 II), 119-126. https://doi.org/10.1177/00034894021110s524

Tomblin, J. B., Spencer, L. J., \& Gantz, B. J. (2000). Language and reading acquisition in children with and without cochlear implants. Advances in Oto-Rhino-Laryngology, 57, 300-304. https://doi.org/10.1159/000059145

Wang, Y., Shafto, C. L., \& Houston, D. M. (2018). Attention to speech and spoken language development in deaf children with cochlear implants: A 10-year longitudinal study. Developmental Science, 21(6), 1-12. https://doi.org/10.1111/desc.12677

Wass, M. (2009). Children with cochlear implants: Cognition and reading ability. Linköping University Electronic Press.

Wechsler-Kashi, D., Schwartz, R. G., \& Cleary, M. (2014). Picture naming and verbal fluency in children with cochlear implants. Journal of Speech, Language, and Hearing Research, 57(5), 1870-1882. https://doi.org/10.1044/2014_JSLHR-L-13-0321

Werfel, K. L. (2017). Emergent literacy skills in preschool children with hearing loss who use spoken language: Initial findings from the early language and literacy acquisition (ELLA) study. Language, Speech, and Hearing Services in Schools, 48(4), 249-259. https://doi.org/10.1044/2017_LSHSS-170023

Werfel, K. L., Douglas, M., \& Ackal, L. (2016). Small-group phonological awareness training for prekindergarten children with hearing loss who wear cochlear implants and/or hearing aids. Deafness \& Education International, 18(3), 134-140. https://doi.org/10.1080/14643154.2016.1190117

Werfel, K. L., Lund, E., \& Schuele, C. M. (2015). Print knowledge of preschool children with hearing loss. Communication Disorders Quarterly, 36(2), 107-111. https://doi.org/10.1177/1525740114539002

Yoshinaga-Itano, C., Baca, R. L., \& Sedey, A. L. (2010). Describing the trajectory of language development in the presence of severe-to-profound hearing loss: A closer look at children with cochlear implants versus hearing aids. Otology and Neurotology, 31(8), 1268-1274.

https://doi.org/10.1097/MAO.0b013e3181f1ce07 
medRxiv preprint doi: https://doi.org/10.1101/2021.03.02.21252684; this version posted March 27, 2021. The copyright holder for this preprint (which was not certified by peer review) is the author/funder, who has granted medRxiv a license to display the preprint in perpetuity. All rights reserved. No reuse allowed without permission.

Supplementary Table A.4 Demographic Information for $\mathrm{Cl}$ versus TH

\begin{tabular}{lcc}
\hline Characteristics for both groups & Cl & TH \\
\hline Mean sample size (range) & $21(4-101)$ & $57(9-554)$ \\
Mean age at testing in months (range) & $99(50-152)$ & $98(46-158)$ \\
Mean percentage of female participants (range) & $46(33-62)$ & $50(31-70)$ \\
Specific Characteristics for Cl group & & \\
\hline Mean age at onset of deafness in months (range) & $11(4-17)$ \\
Mean age at implantation in months (range) & $41(15-132)$ \\
Mean duration of implant use in months (range) & $78(28-157)$ \\
Mean percentage of children with unilateral Cl (range) & $56(14-100)$ \\
Mean unaided pure-tone hearing level in dB (range) & $106(90-119)$ \\
Mean percentage of children using oral communication (range) & $91(50-100)$ & \\
\end{tabular}


medRxiv preprint doi: https://doi.org/10.1101/2021.03.02.21252684; this version posted March 27, 2021. The copyright holder for this preprint (which was not certified by peer review) is the author/funder, who has granted medRxiv a license to display the preprint in perpetuity. All rights reserved. No reuse allowed without permission.

Supplementary Table A.5 Descriptive Statistics of Hedges' $g$ for each construct for $\mathrm{Cl}$ versus TH

\begin{tabular}{lcccc}
\hline & mean & range & standard error & Number of Effects \\
\hline PA & -1.40 & {$\left[\begin{array}{ll}-6.55 & .01\end{array}\right]$} & .23 & 37 \\
Vocabulary & -1.64 & {$\left[\begin{array}{ll}-6.78 & .20\end{array}\right]$} & .25 & 38 \\
Receptive Vocabulary & -1.90 & {$\left[\begin{array}{ll}-6.78 & -.28\end{array}\right]$} & .28 & 31 \\
Expressive Vocabulary & -.50 & {$\left[\begin{array}{ll}-1.15 & .20\end{array}\right]$} & .21 & 7 \\
Decoding & -1.42 & {$\left[\begin{array}{ll}-4.67 & 1.11\end{array}\right]$} & .22 & 31 \\
Fluency & -.65 & {$\left[\begin{array}{lll}-1.72 & -.01\end{array}\right]$} & .19 & 8 \\
Reading Comprehension & -1.49 & {$\left[\begin{array}{lll}-4.57 & 1.01\end{array}\right]$} & .33 & 20 \\
\hline
\end{tabular}


medRxiv preprint doi: https://doi.org/10.1101/2021.03.02.21252684; this version posted March 27, 2021. The copyright holder for this preprint (which was not certified by peer review) is the author/funder, who has granted medRxiv a license to display the preprint in perpetuity. All rights reserved. No reuse allowed without permission.

Supplementary Table A.6 Demographic Information for $\mathrm{Cl}$ versus HA

\begin{tabular}{lcc}
\hline Characteristics for both groups & Cl & HA \\
\hline Mean sample size (range) & $24(7-47)$ & $23(7-71)$ \\
Mean age at testing in months (range) & $113(62-165)$ & $115(62-168)$ \\
Mean percentage of female participants (range) & $43(33-61)$ & $54(33-83)$ \\
HL Characteristics for both groups & & \\
\hline Mean age at onset of deafness/HL in months (range) & $12(6-19)$ & $14(8-35)$ \\
Mean age at implantation/fitting in months (range) & $53(20-129)$ & $28(10-59)$ \\
Mean duration of device use in months (range) & $96(37-157)$ & $83(83-83)$ \\
Mean percentage of children with unilateral Cl (range)* & $56(14-100)$ & \\
Mean unaided pure-tone hearing level in dB (range) & $103(93-117)$ & $88(63-107)$ \\
Mean percentage of children using oral communication (range) & $79(38-100)$ & $75(33-100)$ \\
\hline
\end{tabular}

* many studies did not report bilateral HAs versus a unilateral HA. Thus, only the Cl sample was reported. 
medRxiv preprint doi: https://doi.org/10.1101/2021.03.02.21252684; this version posted March 27, 2021. The copyright holder for this preprint (which was not certified by peer review) is the author/funder, who has granted medRxiv a license to display the preprint in perpetuity. All rights reserved. No reuse allowed without permission.

\section{Supplementary Figure Legends}

Supplementary Figure A.1 Forest Plot for $\mathrm{Cl}$ versus $\mathrm{TH}$

Supplementary Figure A.2 Forest Plot for $\mathrm{Cl}$ versus $\mathrm{HA}$

Supplementary Figure A.3 Funnel Plot for $\mathrm{Cl}$ versus TH

Supplementary Figure A.4 Funnel Plot for $\mathrm{Cl}$ versus HA 
(Asker-Arason, 2015)
(Aster-Arimason, 2015)-Read

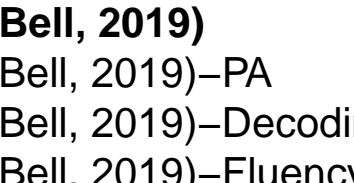

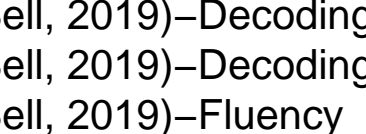

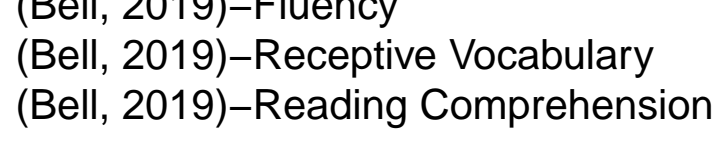

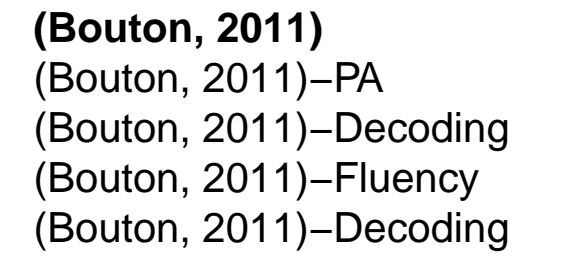

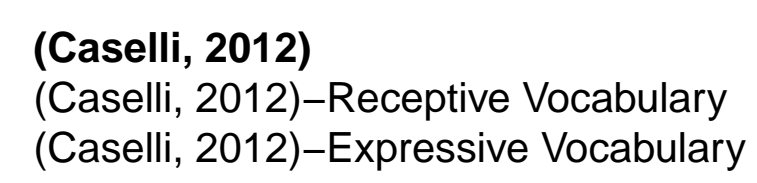

(Cirmeci, 2018a)
$($ Cizmeci, 2018a)

(Cirmeci, 2018b)
(Çirmeci, 20186)-Reading comprehension

(Conway, 2011)
(Convay, 2011)-Recopivive Vocabulary

(Covertino, 2014)
(Covertino, 2014)-R

(Covertino, 2014)-Sample2
(Covertino, 2014)-Sample2-Rea

(Covertinin, 2014)-Sample3
(Covertino, 2014)-Sample3-P

(Davidson, 2014)
(Davivson, 2014)-Recepivive Vocabulary

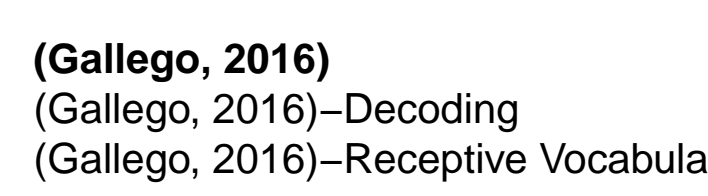

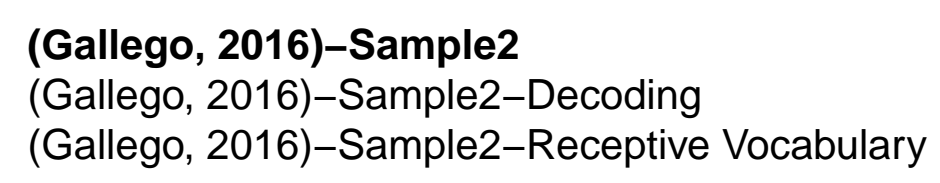

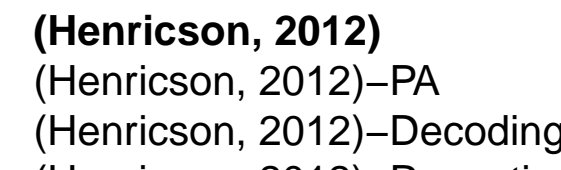

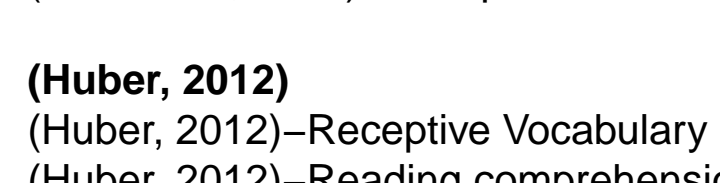

(James, 2002)
(James, 2002)-PA
(James, 20202)-PA

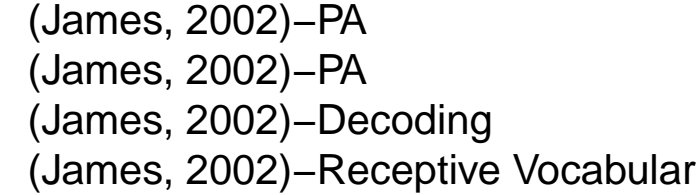

(James, 2020)-Sample2
(Jams, 2002)-Sample2-PA
(James, 2002)-Sample-2-PA

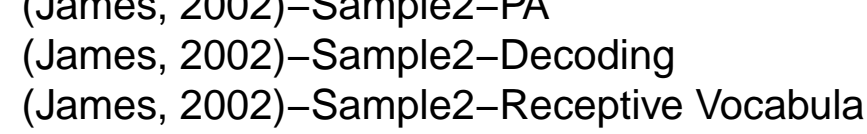

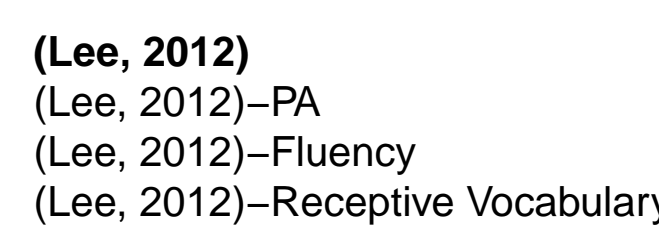

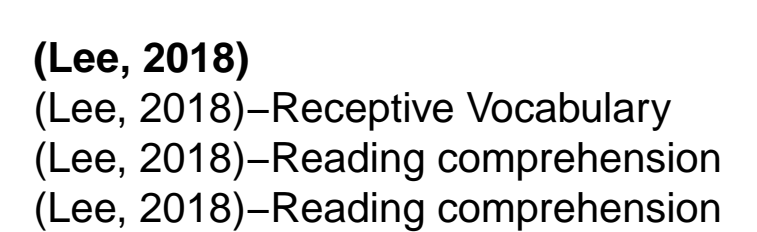

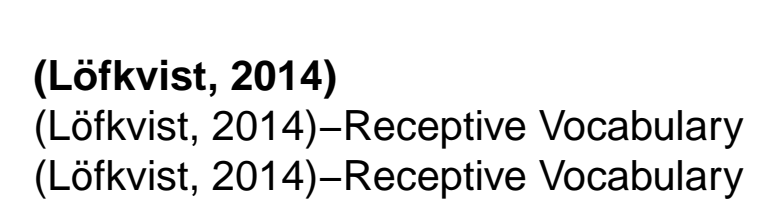

(Luckhurst, 2013)
(Luckhurst, 2013)-Recepivive Vocabulary
(Luckhurst, 2013)-Expressive Vocabaluary

(Mandal, 2016)
(Mandal), 2016)-Bes

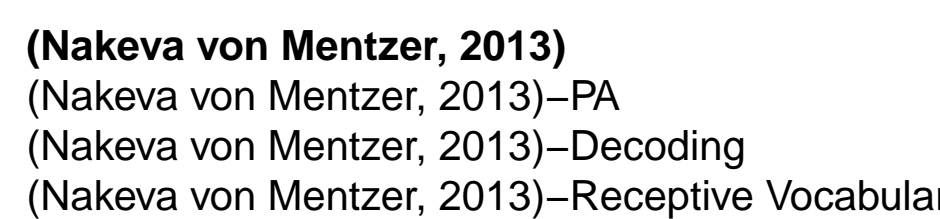

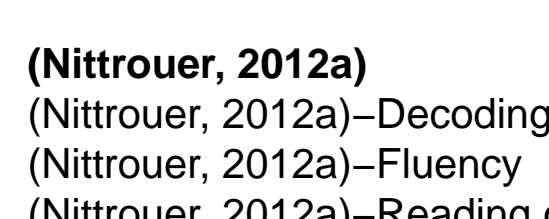

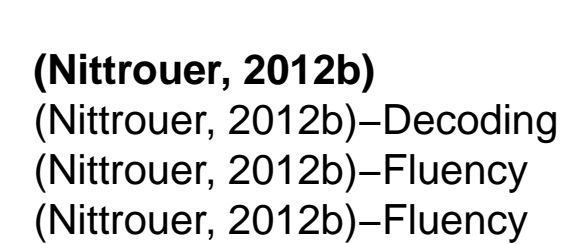

ehension

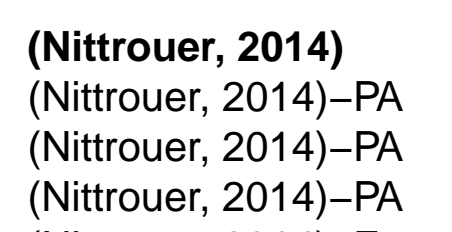

(Nitrouer, 2015)
(Nitrouer, 2015)-PA

(Nitrouer, 2016a)
(Nitrouer, 2016a)-Decoding
(Nitrouer, 2016a)-Reading comprehension

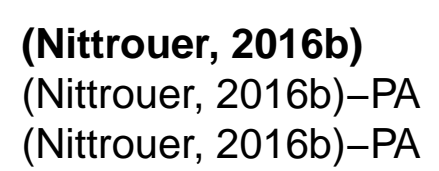

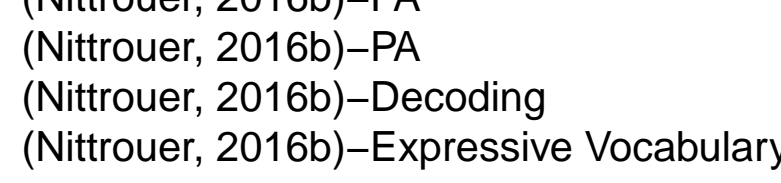

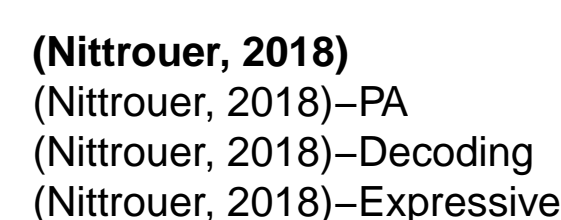

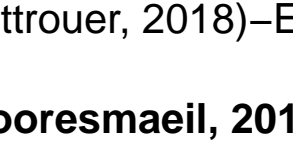

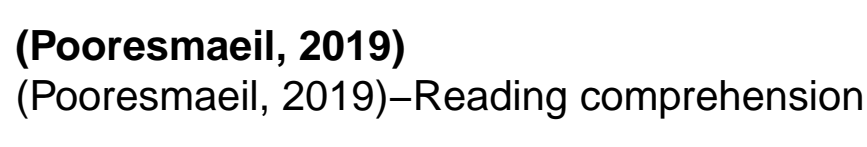

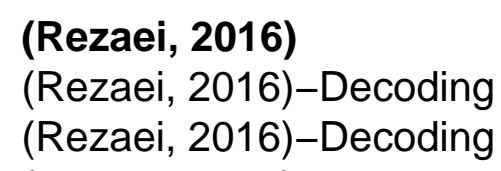

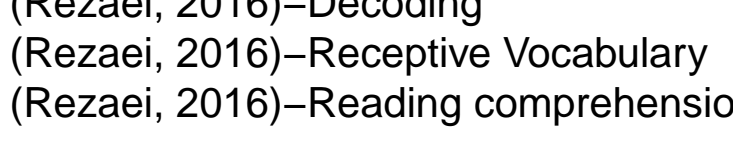

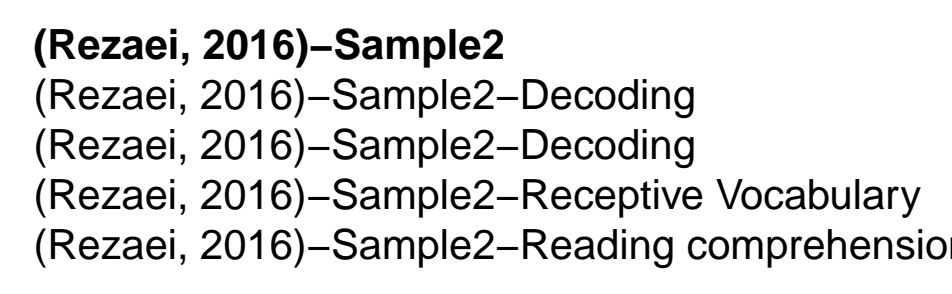

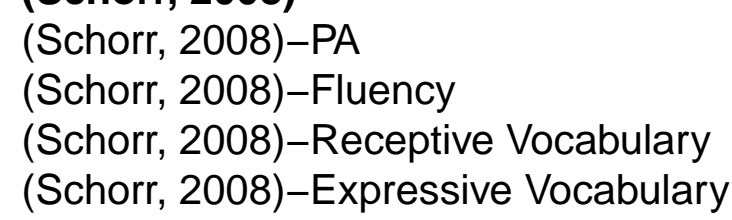

(Soleyymani, 2016)-
(Soly
(Solymanani, 2016)-PA

(Spenerer, 2003)-
(Spencer, 2003)-Red

(Torres, 2008)
(Torres, 2008)-Rea

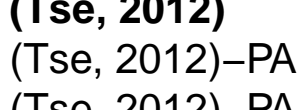

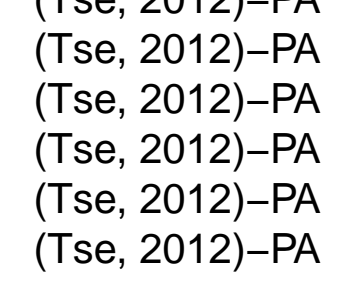

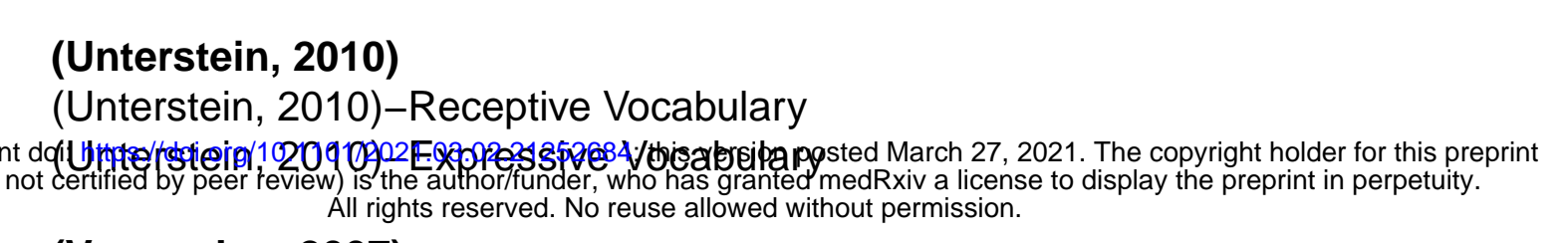
(Vermeulen, 2007)-D
(Vermeulen, 2007)-Decoding

(Nermeulen, 2007-SSample2
(Vermulen, 2007)-Sample2-Decoding

Nermeulen, 2007-SSample3
(vermenten, 2007)-Samples-Decoding

Nermeulen, 2007-Samplea
(Nermeunen, 2007)-Sanple4-Decoding

(Walker, 2013)
(Waker, 2013)-Receppive Vocabulary

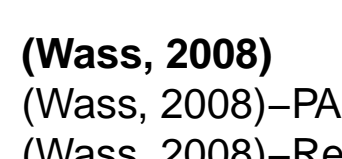

iviv vocabu

(Wechster-Kashi, 2010)
(Wechsler-Kashi, 2010)-Receppive Vocabulary

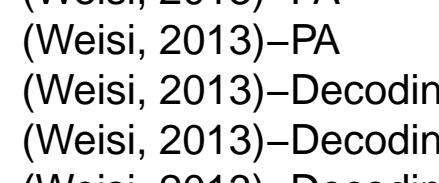

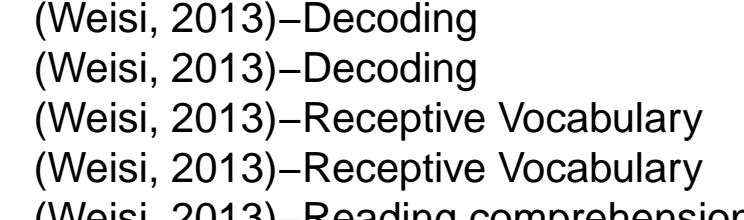

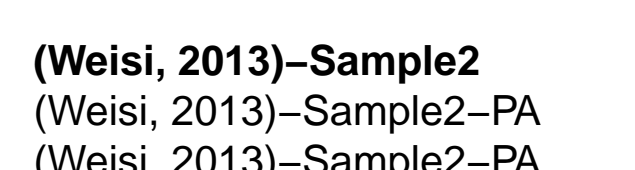

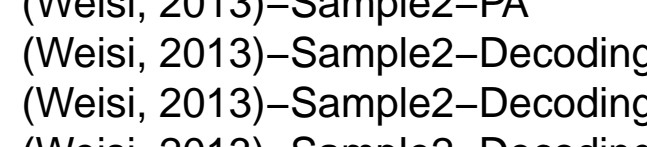




\section{Forest Plot}

Studies

(Rezaei, 2016)

Rezaei, 2016)-Reading comprehension Rezaei, 2016)-Word-level reading (Rezaei, 2016)-Phonics

(Rezaei, 2016)-Sample2 (Rezaei, 2016)-Sample2-Vhonics

(Ching, 2015)

(Ching, 2015)-PA

(Ching, 2015)-Vocabulary

\section{(Asker-Arnason, 2015)}

(Asker-Árnason, 2015)-Reading comprehension

Nittrouer, 2012-2015)-PA

(1)

(Nitrour, 2012-2015)-Word-

(Nitrouer, 2012-2015)-Word-level reading

(Nittrouer, 2012-2015)-Word-level reading4

(Nittrouer, 2012-2015)-PA2

(Nittrouer, 2012-2015)-PA3

(Nittrouer, 2012-2015)-PA4

(Nittrouer, 2012-2015)-Vocabulary

(Convertino, 2014)

Convertino, 2014)-Reading comprehension

(Convertino, 2014)-Sample2

(Convertino, 2014)-Sample2-Reading comprehension

(Convertino, 2014)-Sample3

(Convertino, 2014)-Sample3-Vocabulary

Nakeva von Mentzer, 2013)

(Nakeva von Mentzer, 2013)-PA

(Nakeva von Mentzer, 2013)-PA2

Nakeva von Mentzer, 2013)-Phonics

Nakeva von Mentzer, 2013)-Vocabulary

(Henricson, 2012)

(Henricson, 2012)-PA

(Henricson, 2012)-Vocabulary

(...van der Kant, 2010)

(...van der Kant, 2010)-Reading comprehension

(Harris, 2011)

ding comprehension

(Harris, 2011)-Word-level reading

(Harris, 2011)-Sample2

(Harris, 2011)-Sample2-Reading comprehension

(Harris, 2011)-Sample2-Word-level reading

(Law, 2006)

Law, 2006)-Vocabulary
(Rezaei, 2016)-Sample2-Reading comprehension (Rezaei, 2016)-Sample2-Word-level reading

(Nittrouer, 2012-2015)

Effect Size

Cl sample size

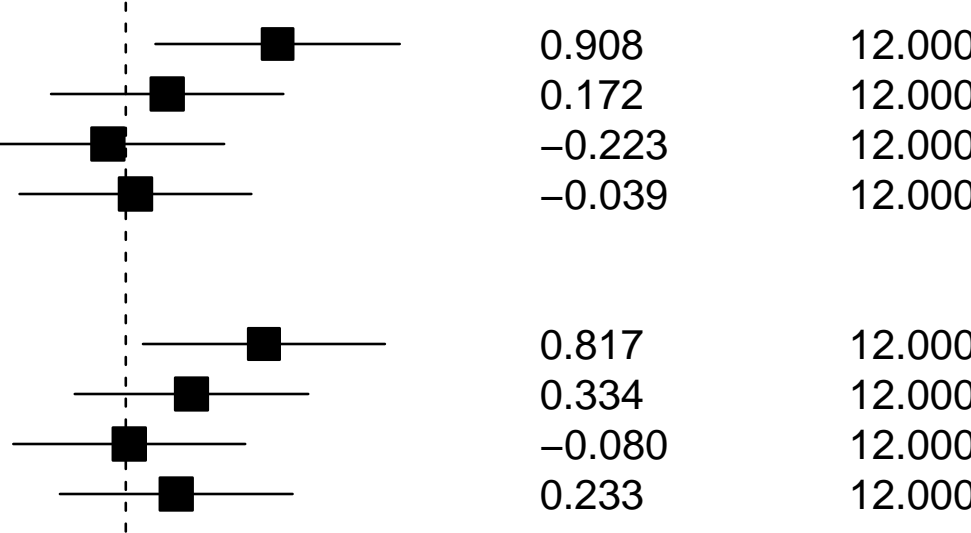

$-0.188$

30.000

$\begin{array}{l:ll} & & 0.188\end{array}$

23.000

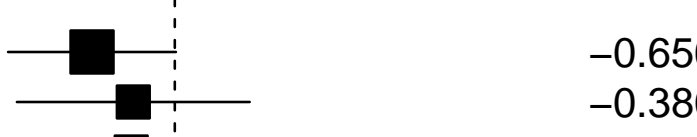

$-0.394 \quad 27.000$

$\begin{array}{ll}-0.095 & 25.000 \\ -0.527 & 27.000\end{array}$

$-0.337 \quad 27.000$

$\begin{array}{ll}-0.454 & 27.000 \\ -0.228 & 27.000\end{array}$

$\begin{array}{ll}-0.571 & 27.000 \\ -0.569 & 27.000\end{array}$

$\begin{array}{ll}-0.269 & 27.000\end{array}$

0.297

31.000

32.000

30.000

17.000

17.000

17.000
17.000

10

$-1.334=28.000$

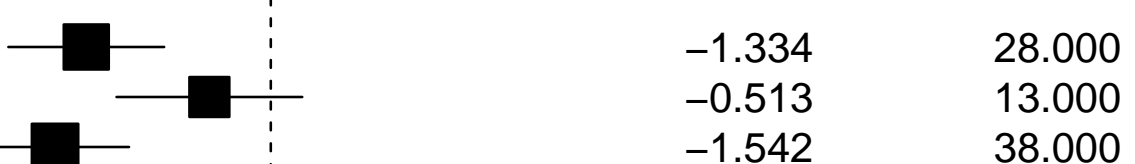

38.000

44.000

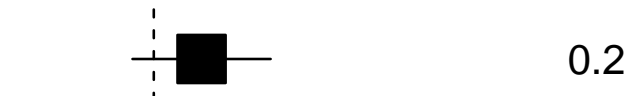

$-0.449 \quad 30.000$
0.126

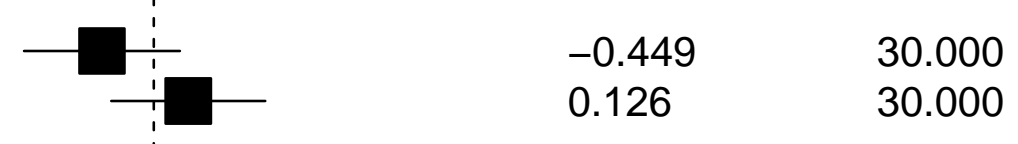

-

29.000

0.185

7.000

$\begin{array}{ll}0.299 & 20.000\end{array}$

$\begin{array}{ll}0.299 & 20.000 \\ 0.300 & 20.000\end{array}$

$0.134-2000$

$\begin{array}{ll}0.778 & 20.000 \\ 0.382 & 20.000\end{array}$

nson, 2010)-Word-level reading3

Johnson, 2010)-Vocabulary

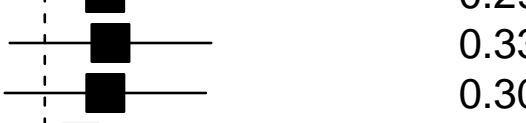

$\sqrt{\square} \quad 0.778$

20.000

(Johnson, 2010)-Sample2

(Johnson, 2010)-Sample2-Reading comprehension

(Johnson, 2010)-Sample2-Word-level reading

(Johnson, 2010)-Sample2-Word-level reading2

(Johnson, 2010)-Sample2-Word-level reading

(Johnson, 2010)-Sample2-Vocabulary
(Johnson, 2010)-Sample2-Vocabulary2

(James, 2002)

(James, 2002)-Word-level reading
(James, 2002)-PA

(James, 2002)-PA2

(James, 2002)-PA3

(James, 2002)-Vocabulary

(James, 2002)-Sample2

(James, 2002)-Sample2-Word-level reading2

(James, 2002)-Sample2-PA

(James, 2002)-Sample2-PA2

(James, 2002)-Sample2-Vocabulary

(Arrington, 2018)

(Arrington, 2018)-Vocabulary
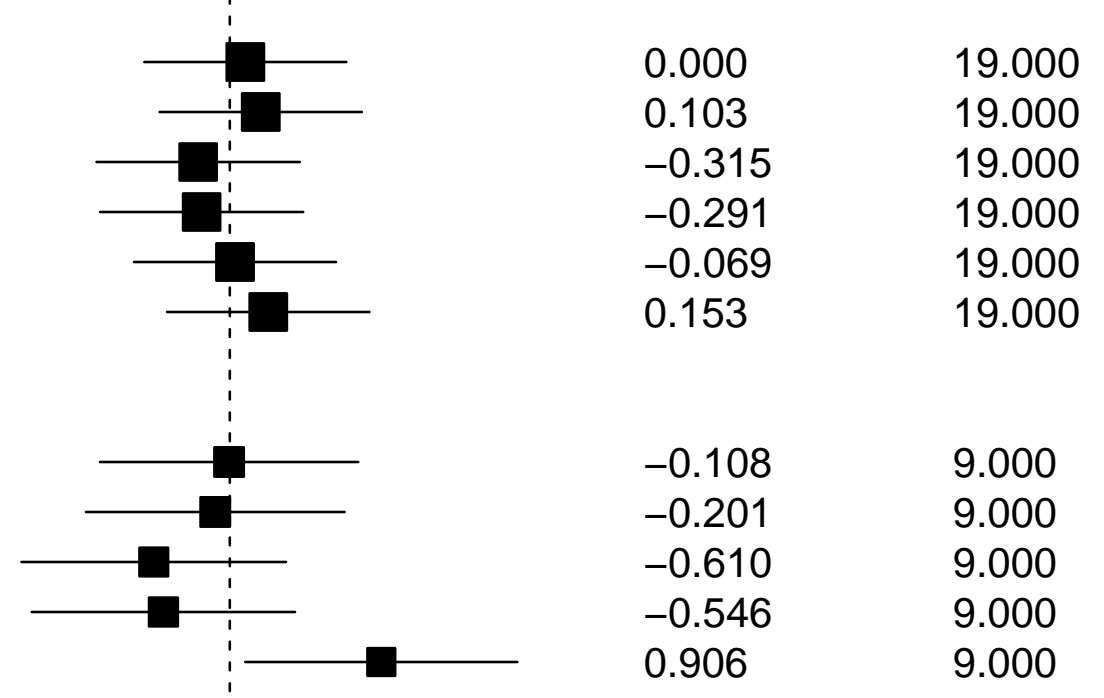

$\begin{array}{ll}-0.111 & 10.000 \\ 0.570 & 10.000\end{array}$

$\begin{array}{ll}-0.570 & 10.000 \\ -0.282 & 10.000\end{array}$

$\begin{array}{ll}-0.282 & 10.000 \\ -0.599 & 10.000\end{array}$

$0.638 \quad 18.000$

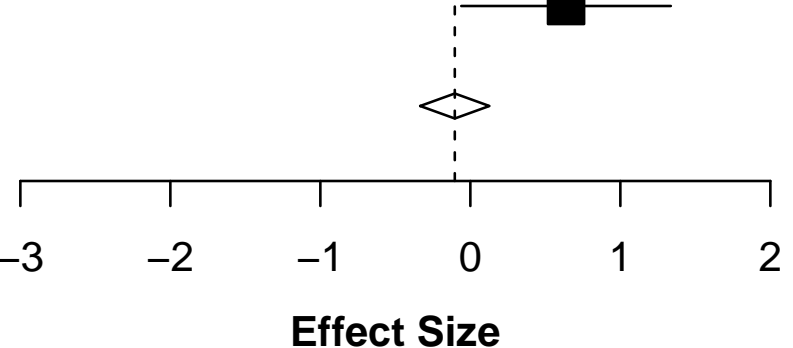




\section{$\mathrm{Cl}$ versus $\mathrm{TH}$ : Funnel Plot}

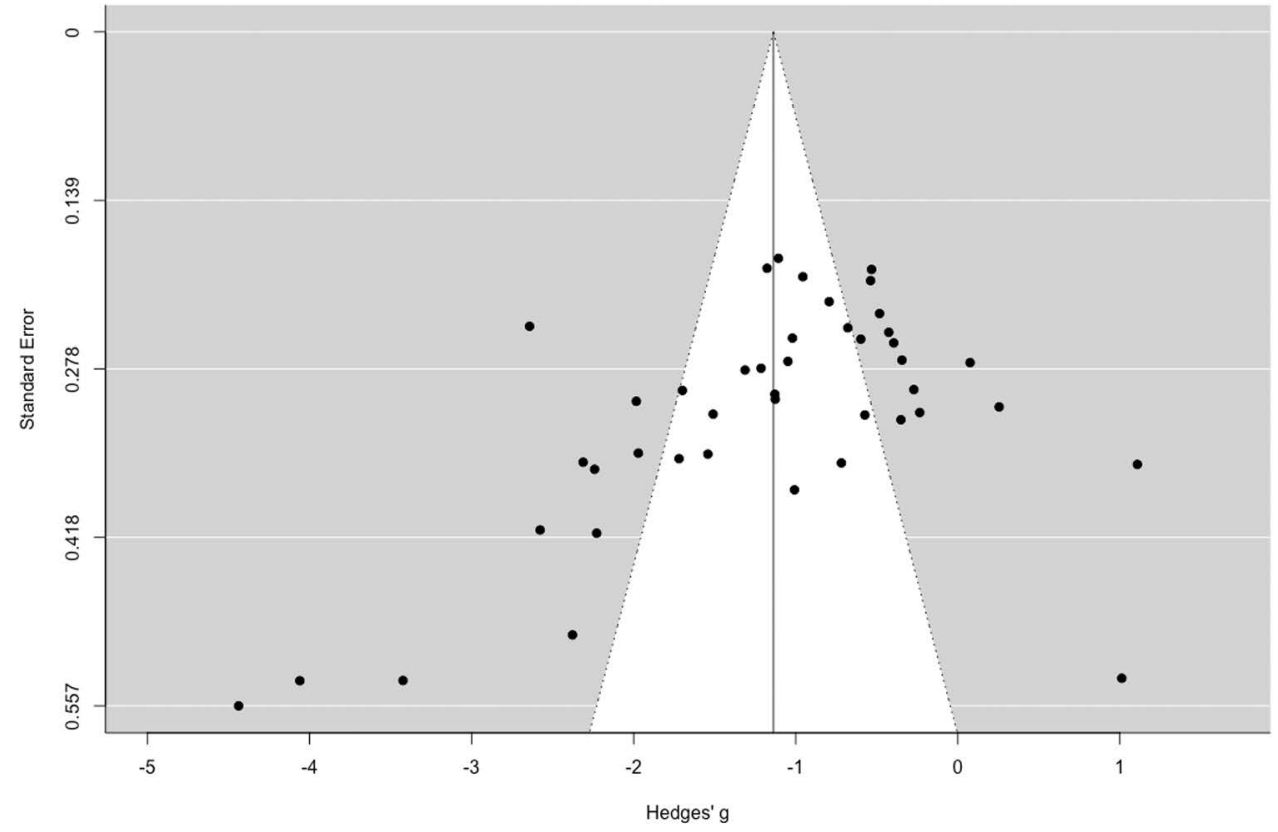




\section{$\mathrm{Cl}$ versus HA: Funnel Plot}

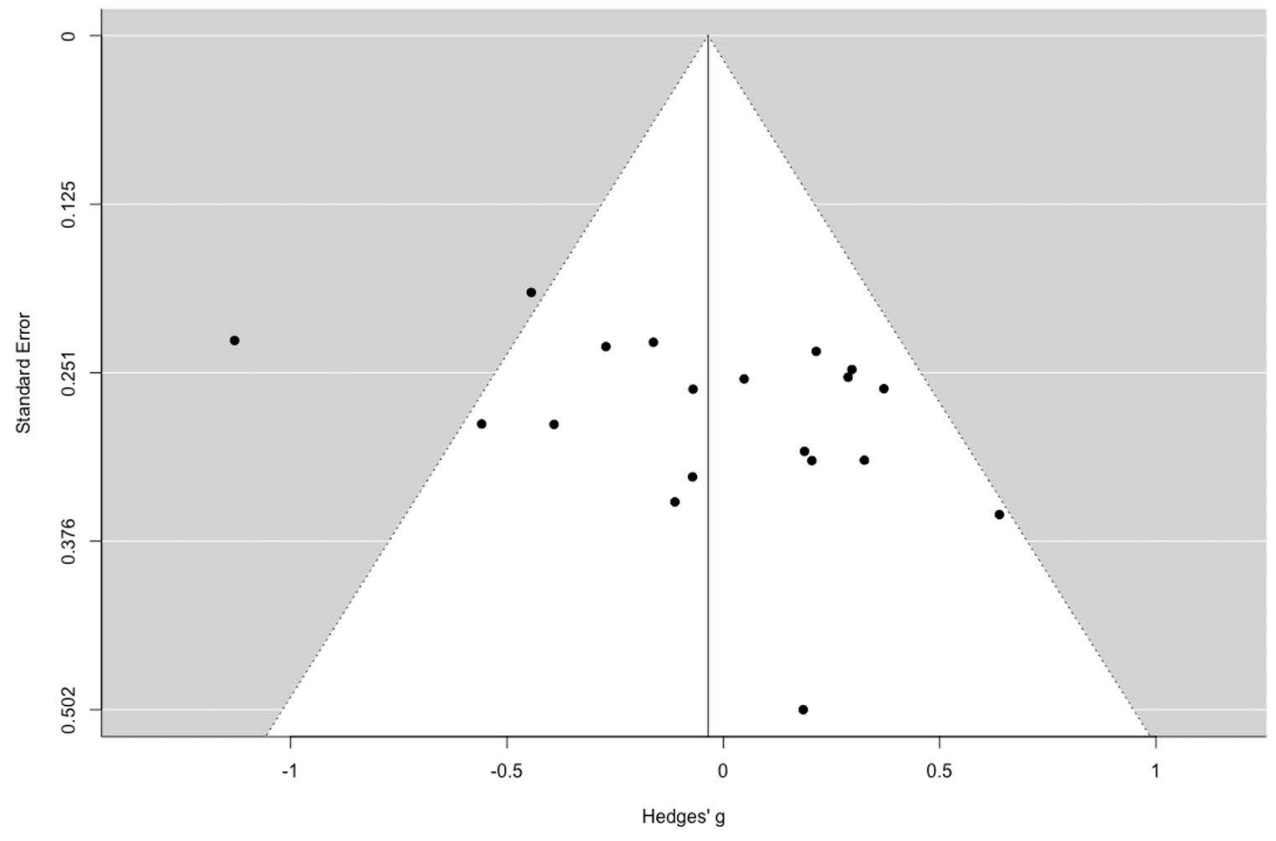

